\title{
Tungsandsforekomster i Danmark
}

\author{
Af \\ Werner Christensen og Gunnar Larsen
}

English Summary:

Occurences of Heavy Mineral Sands

(Placer Deposits) in Denmark

I Kommission hos

C. A. REITZELS FORLAG (JØRGEN SANDAL)

KØBENHAVN 1960 
Med 8 tavler

With 8 plates 


\section{DANMARKS GEOLOGISKE UNDERSØGELSE}

III. RAKKE. NR. 33

Geological Survey of Denmark. III. Series. No. 33

\section{Tungsandsforekomster \\ i Danmark}

Af

Werner Christensen og Gunnar Larsen

English Summary:

Occurences of Heavy Mineral Sands

(Placer Deposits) in Denmark

I kommission hos

C. A. REITZELS FORLAG (JØRGEN SANDAL)

KøBENHAVN 1960 
Med 8 tavler

With 8 plates 


\section{FORORD}

Undersøgelserne af de danske tungsandsaflejringer, hvis resultater herved offentligg $\emptyset$ res, påbegyndtes i foråret 1956 af førstnævnte forfatter, idet han efter forespørgsel fra firmaet A. Laursen, Odense, vedrørende forekomst af titanmalm skønnede, at der var mulighed for, at egnede råstoffer fandtes her i landet. Han foretog derfor et par orienteringsrejser til Nordsjællands kyster, hvorved det konstateredes, at malmholdige sandaflejringer fandtes i ret betydelig mængde.

Af hensyn til vurderingen af materialets sammensætning var en petrografisk unders $\emptyset$ gelse nødvendig. Der indledtes derfor et samarbejde med sidstnævnte forfatter, som har forestået og udført det petrografiske analysearbejde. - Præparation af materiale til petrografisk analyse er for en stor del udf $\varnothing \mathrm{rt}$ af præparator H. BAHNSEN.

Til supplering af de petrografiske unders $\varnothing$ gelser er der på D.G.U.'s kemiske laboratorium udf $\phi r t$ bestemmelse af titan og jern i et betydeligt antal prøver. Endvidere er der på kemisk laboratorium foretaget magnetsortering af tungsand og udf $\phi r t$ bestemmelse af jern, titan og uopløselig rest i malmfraktioner med forskellig magnetisk styrke. Undersøgelserne på kemisk laboratorium er udført af fru B. Dinesen samt K. Skousb $\emptyset$ ll Hansen og H. Kristiansen.

Malmmikroskopiske undersøgelser af enkelte prøver i forbindelse med oparbejdningsfors $\emptyset \mathrm{g}$ er foretaget af dr. phil. H. PAuly på Kryolitselskabet $\gg$ resund i vinteren 1959. Disse analyseresultater er venligst stillet til D.G.U.'s rådighed.

Samtlige tegninger er udført på D.G.U.'s tegnestue af fru R. Bong. Fotografering af præparater af tungsand er foretaget af CHR. WesterGAARD.

De nævnte, som har deltaget i arbejdet, samt andre, der ved meddelelser og diskussioner har bidraget til belysning af forhold vedrørende de danske tungsandsforekomster, bedes modtage vor bedste tak.

Charlottenlund, september 1959.

Werner Christensen Gunnar Larsen 
$\begin{array}{lllllllllllllllllllll}\text { Forord . } & \ldots & \ldots & \ldots & \ldots & \ldots & \ldots & \ldots & \ldots & \ldots & \ldots & \ldots & \ldots & \ldots & \ldots & \ldots & 3\end{array}$

$\begin{array}{llllllllllllllllll}\text { Abstract } & \ldots & \ldots & \ldots & \ldots & \ldots & \ldots & \ldots & \ldots & \ldots & \ldots & \ldots & \ldots & \ldots & \ldots & \ldots & 7\end{array}$

$\begin{array}{llllllllllllllll}\text { Indledning } \ldots & \ldots & \ldots & \ldots & \ldots & \ldots & \ldots & \ldots & \ldots & \ldots & \ldots & \ldots & \ldots & \ldots & \ldots & 8\end{array}$

$\begin{array}{lllllllllllllllll}\text { Historisk oversigt } & \ldots & \ldots & \ldots & \ldots & \ldots & \ldots & \ldots & \ldots & \ldots & \ldots & \ldots & \ldots & 8\end{array}$

Nærværende undersøgelser $\begin{array}{lllllllllllllll} & \ldots & \ldots & \ldots & \ldots & \ldots & \ldots & \ldots & \ldots & \ldots & \ldots & 9\end{array}$

Tungsandsforekomster (af Werner Christensen) $\ldots \begin{array}{lllllllllll} & \ldots & \ldots & \ldots & \ldots & \ldots & 11\end{array}$

$\begin{array}{llllllllllllll}\text { Almene karakterer } & \ldots & \ldots & \ldots & \ldots & \ldots & \ldots & \ldots & \ldots & \ldots & \ldots & \ldots & \ldots & 11\end{array}$

$\begin{array}{lllllllllllll}\text { Rekognosceringernes hovedresultater } & \ldots & \ldots & \ldots & \ldots & \ldots & \ldots & \ldots & \ldots & 13\end{array}$

Beskrivelse af forekomsterne $\ldots \begin{array}{llllllllllllllll} & \ldots & \ldots & \ldots & \ldots & \ldots & \ldots & \ldots & \ldots & \ldots & 13\end{array}$

Jyllands vestkyst $\ldots \begin{array}{lllllllllllllll} & \ldots & \ldots & \ldots & \ldots & \ldots & \ldots & \ldots & \ldots & \ldots & \ldots & \ldots & 13\end{array}$

$\begin{array}{lllllllllllllll}\text { Jyllands } \text { østkyst } & \ldots & \ldots & \ldots & \ldots & \ldots & \ldots & \ldots & \ldots & \ldots & \ldots & \ldots & \ldots & 20\end{array}$

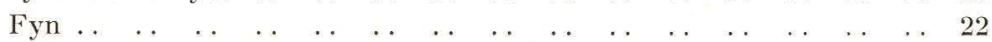

Sjælland $\ldots \begin{array}{llllllllllllllll} & \ldots & \ldots & \ldots & \ldots & \ldots & \ldots & \ldots & \ldots & \ldots & \ldots & \ldots & \ldots & \ldots & 22\end{array}$

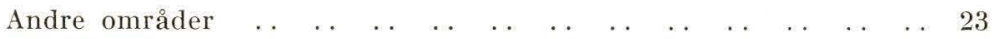

Tungsandsaflejringernes dannelse (af Werner Christensen). . . . . . . 25

Koncentrationsprocessen på stranden $\ldots \begin{array}{llllllllllllll} & \ldots & \ldots & \ldots & \ldots & \ldots & \ldots & \ldots & 25\end{array}$

$\begin{array}{llllllllllllllll}\text { Vindens virkning } & \ldots & \ldots & \ldots & \ldots & \ldots & \ldots & \ldots & \ldots & \ldots & \ldots & \ldots & \ldots & 29\end{array}$

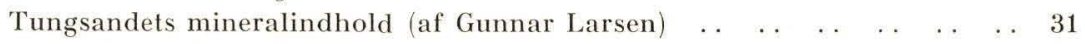

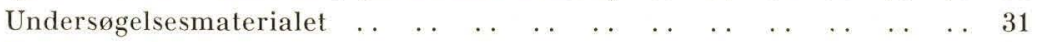

$\begin{array}{llllllllllllll}\text { Undersøgelsesmetoder } & \ldots & \ldots & \ldots & \ldots & \ldots & \ldots & \ldots & \ldots & \ldots & \ldots & \ldots & 31\end{array}$

$\begin{array}{lllllllllllllllllll}\text { Mineralerne . } & \ldots & \ldots & \ldots & \ldots & \ldots & \ldots & \ldots & \ldots & \ldots & \ldots & \ldots & \ldots & \ldots & 33\end{array}$

$\begin{array}{llllllllllllllllll}\text { Mineralfordelingen } & \ldots & \ldots & \ldots & \ldots & \ldots & \ldots & \ldots & \ldots & \ldots & \ldots & \ldots & \ldots & 35\end{array}$

Sammenligning mellem petrografisk og kemisk analyse . . . . . 35

Mineralfordelingens relation til koncentrationsgraden $\ldots . . \quad \ldots \quad 37$

Mineralfordelingens relation til kornstørrelsen $\ldots \begin{array}{lllllllll} & \ldots & \ldots & \ldots & 39\end{array}$

Geologisk vurdering af mineralindholdet (af Gunnar Larsen) . . . . . . 41

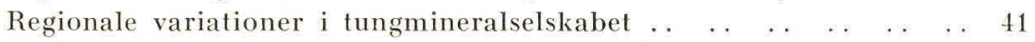

$\begin{array}{lllllllllllll}\text { Bedømmelsesbasis } & \ldots & \ldots & \ldots & \ldots & \ldots & \ldots & \ldots & \ldots & \ldots & \ldots & \ldots & 41\end{array}$

$\begin{array}{llllllllllllll}\text { De regionale variationer } & \ldots & \ldots & \ldots & \ldots & \ldots & \ldots & \ldots & \ldots & \ldots & \ldots & 42\end{array}$

$\begin{array}{lllllllllllll}\text { Variationernes } \operatorname{argsag} & \ldots & \ldots & \ldots & \ldots & \ldots & \ldots & \ldots & \ldots & \ldots & \ldots & \ldots & 43\end{array}$

$\begin{array}{llllllllllllll}\text { Praktiske resultater } & \ldots & \ldots & \ldots & \ldots & \ldots & \ldots & \ldots & \ldots & \ldots & \ldots & \ldots & 44\end{array}$

$\begin{array}{llllllllllllllll}\text { Materialets oprindelse } & \ldots & \ldots & \ldots & \ldots & \ldots & \ldots & \ldots & \ldots & \ldots & \ldots & \ldots & 46\end{array}$

Tungsandets udnyttelsesmuligheder (af Werner Christensen) $\ldots . . . \quad \ldots \quad 48$

Mængde $\operatorname{og}$ koncentration $\ldots \begin{array}{lllllllllll} & \ldots & \ldots & \ldots & \ldots & \ldots & \ldots & \ldots & \ldots & \ldots & 48\end{array}$

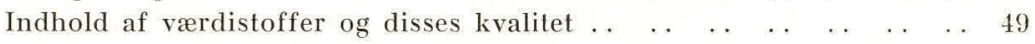

$\begin{array}{llllllllllll}\text { Nogle oparbejdningsforsøg } & \ldots & \ldots & \ldots & \ldots & \ldots & \ldots & \ldots & \ldots & \ldots & 49\end{array}$

Kemisk analyse af magnetsepareret materiale . . $\quad \ldots \quad \ldots \quad \ldots \quad \ldots \quad 51$

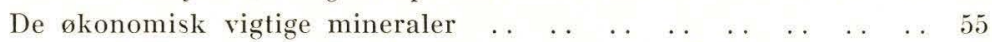

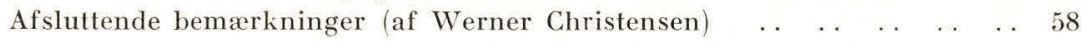

$\begin{array}{lllllllllllllllllll}\text { Summary } & \ldots & \ldots & \ldots & \ldots & \ldots & \ldots & \ldots & \ldots & \ldots & \ldots & \ldots & \ldots & \ldots & \ldots & \ldots & 60\end{array}$

$\begin{array}{llllllllllllllllllll}\text { Litteratur } & \ldots & \ldots & \ldots & \ldots & \ldots & \ldots & \ldots & \ldots & \ldots & \ldots & \ldots & \ldots & \ldots & \ldots & \ldots & 62\end{array}$ 


\section{ABS TRACT}

Occurrences of heavy minerals along the coasts of Denmark have been investigated for the purpose of clarifying the question of to what extent these deposits contain minerals of economic importance in such quantities as to make extraction worth while.

The plan included field studies of the nature and size of the occurrences as well as laboratory analyses of the mineral content in the sand.

It has been ascertained that there are about 25 kilometres of beach in all with a high content of well-concentrated heavy mineral sand. The quantity of this sand is estimated at about 100,000 tons. Most of the large deposits were found to be in northern and western Jutland. It was ascertained that the following minerals assumed to be of economic importance were present: magnetite, ilmenite (containing haematite), and zircon. Other minerals, for example garnet, may prove useful as a by-product of extraction. 


\section{N D LE D N I N G}

Ved de danske kyster findes udbredte forekomster af sand, dels på strandbredder, dels i klitter. Disse sandaflejringer er almindeligvis lyse og består fortrinsvis af mineralet kvarts, samt af en del feldspat og underordnede mængder af tungmineraler.

Ved tungmineraler forstås mineraler, hvis vægtfylde er større end eller lig med $2,9 \mathrm{~g} / \mathrm{cm}^{3}$. Til sammenligning skal nævnes, at vægtfylden for de lette mineraler kvarts og feldspat er ca. 2,7. Tungmineraler er ofte ret kraftigt farvede. De kan f. eks. være sorte, rødlige, grønlige.

I de lyse sandaflejringer kan undertiden træffes forekomster af mørkt, tungmineralrigt sand. Sådanne forekomster betegnes tungsand. Den del af tungsandet, der består af malmmineraler (magnetit, ilmenit, hæmatit) kaldes malmsand. Undertiden ses anvendt andre betegnelser, f. eks. magnetsand, titansand, granatsand. Disse navne henviser til, at det dominerende mineral er henholdsvis magnetit (magnetjern), ilmenit (titanjern) og granat.

Tungsandsforekomster indeholdende $\phi$ konomiske mineraler har været kendt og udnyttet til malmproduktion adskillige steder i udlandet gennem betydelige tidsrum (se f.eks. W.Lindgreen, 1933; N. H. MaGnusSon, 1953; J. B. DE Mille, 1947). Sådanne aflejringer kaldes i Tyskland »Seifen«, medens man i engelsk litteratur ofte benytter betegnelsen $»$ Placer deposits $\ll$.

\section{Historisk oversigt.}

Den geologiske litteratur rummer kun sparsomme oplysninger om danske tungsandsaflejringer.

De første optegnelser findes hos J. G. Forсннамmer, der i artiklen »Klitterne på den jydske Halv $\varnothing$ (trykt f $\emptyset$ rste gang i 1842) anfører: $\gg$ I den nordlige Deel og navnlig ved Skagen indeholder Klitsandet meget Titanjern og Granat«.

I beskrivelsen til de geologiske kortblade Helsing $\varnothing \mathbf{r}$ og Hiller $\phi \mathbf{d}$ omtaler K. RøRDAm (1893), at strandsandet flere steder langs kysten er »rigt på Magnetjernsten, der undertiden ved Bølgeslaget udsorteres 
og aflægges i tommetykke Striber langs Kysten. En lignende Sortering foretages også undertiden ved Vindens Hjælp«.

A. Jessen (1897) meddeler i beskrivelsen til kortbladet Anholt, at alt strandsandet her er meget rigt på jernmineraler, især magnetjernsten.

I en betonteknologisk afhandling fra 1911 anf $\phi$ rer J. K. Dan $\varnothing$, at sandprøver undertiden kan indeholde meget magnetjernsten. Det kan bl. a. forekomme sammen med meget grove sandkorn.

I R. WEYL's arbejde fra 1937 om tungsandsaflejringer i Slesvig og Holsten findes f $\varnothing$ lgende analyse af en strandsandsprøve fra L $\phi$ nstrup Klint i Nordjylland:

Malme $\ldots \ldots \ldots \ldots \ldots \ldots \ldots \ldots \ldots \ldots \ldots$
Granat $\ldots \ldots \ldots \ldots \ldots \ldots \ldots$
Øvrige tungmineraler $\ldots \ldots \ldots \ldots$
Lette mineraler $\ldots \ldots \ldots \ldots \ldots$

Malmene består dels af magnetiske mineraler (magnetit), dels og overvejende af umagnetiske mineraler (sandsynligvis hovedsagelig ilmenit).

Disse spredte oplysninger repræsenterer stort set det kendskab, man i foråret 1956 havde til forekomster og sammensætning af tungsand i Danmark.

\section{Nærværende undersøgelser.}

Anledningen til tungsandsunders $\varnothing$ gelsernes påbegyndelse var som nævnt en forespørgsel fra firmaet A. Launsen, Odense, vedrørende forekomster af titanmalm. Førstnæunte forfatter sk $\phi$ nnede, at såanne malmforekomster muligvis kunne findes i vore strandsandsaflejringer og foretog derfor et par rekognosceringer ved Nordsjællands kyster. Det konstateredes herved, at strandsandet stedvis indeholdt betydelige forekomster af velkoncentreret tungsand. Analyser af hjembragte pr $\varnothing$ ver godtgjorde, at der fandtes et stort indhold af malmmineraler, både magnetit og ilmenit, i tungsandet.

Disse resultater medførte, at der iværksattes en mere omfattende unders $\emptyset$ gelse for at få klarlagt, hvorvidt malmholdigt tungsand fandtes i sådanne mængder og koncentrationer, at en industriel udnyttelse var mulig.

Opgaven har været inddelt i følgende unders $\phi g e l s e s g r u p p e r:$

1. Feltobservationer: undersøgelse af kystområder; skønsmæssig bed $\varnothing$ mmelse af forekomsternes art og størrelse; indsamling af prøver til analyse for mineralindhold. 
10 W. Christensen og G. Larsen: Tungsandsforekomster i Danmark.

2. Laboratorieunders $\emptyset$ gelse: kvantitativ bestemmelse af pr $\varnothing$ vematerialets mineralindhold ved hjælp af kemisk og petrografisk metodik.

Feltarbejdet er for en stor del udf $\phi$ rt lejlighedsvis i forbindelse med andre arbejder. Unders $\phi$ gelsesresultaterne er forel $\phi$ big rent orienterende, idet der ikke er udf $\phi$ rt en systematisk gennemgang og opmåling af tungsandsforekomster i alle kystområder og heller ikke en systematisk indsamling af pr $\varnothing$ ver i de unders $\varnothing$ gte forekomster. - Hovedparten af unders $\emptyset$ gelserne er udf $\emptyset$ rt i nord- og vestjydske kystområder, hvor de største mængder af velkoncentreret tungsand fandtes.

Under opgavens løsning har der været et vist samarbejde med firmaet A. Launsen, der arbejder med planer om en udvinding af malmene. Resultaterne af de sorterings- og oparbejdningsfors $\varnothing$ g, firmaet i denne forbindelse har ladet udf $\varnothing$ re i England og Sverige, er stillet til D. G.U.'s rådighed. 


\title{
TUNGSANDSFOREKOMSTER
}

Der er ikke foretaget en fuldstændig gennemgang af alle kystområder, og der kan derfor ikke gives en udtømmende beskrivelse af vore tungsandsforekomster.

\begin{abstract}
Almene karakterer.
Overalt, hvor man har en strandbred med sand, der lejlighedsvis overskylles af bølger af en vis styrke, vil der være mulighed for koncentrationer af tungsand. Også ved søbredder kan der dannes tungsandskoncentrater, og sådanne er iagttaget ved Arres $\emptyset$ og ved Moss $\varnothing$. Betragter vi forholdene på en strandbred med nogenlunde mængder af tungsand, da kan følgende tilstand anses for typisk efter en tids roligt vejr med normal vandstand på strandbred med overvejende sandaflejringer.

Ude i selve bølgeslagsområdet finder man på den skrå sandflade et ganske tyndt overtræk af tungsand, og er havet eller bølgerne faldende, ser man også det tynde lag noget højere oppe, hvor bølgerne ikke når på det tidspunkt.

På mellemstranden har overfladen ofte en mørk schattering på grund af, at det mørke, tunge sand aflejres som tynde overfladelag, der særlig lægger sig i lavningerne på den af vinden fremkaldte småbølgede overflade. På den høje strand kan overfladen have et lignende udseende helt ind til klinten, men ofte er der her et mørkt overfladelag. Hvor der er meget tungsand på kysten, vil klitter inde bag stranden også være mørke på overfladen, særlig i læsiden, på grund af et ganske tyndt overfladelag af tungsand.

Efter en storm, hvor bølgerne har været helt oppe ved klintfoden, finder man i tungsandsområder ofte, at en varierende del af mellemstrandens overflade er dækket af m $\varnothing r k t$, mere eller mindre r $\varnothing$ dligt tungsand, og at det mørke sand er endnu mere udbredt på den $\varnothing$ vre strand og går helt op på klintfoden, det vil sige, at tungsandet har samlet sig på den høje strand og mellemstranden.
\end{abstract}

Graver man nu et profil på tværs af strandbredden, helt ude fra 
vandet og ind i klintfoden i et sådant tungsandsområde, vil forholdene variere betydeligt fra sted til sted og indenfor samme område også fra tid til anden, men der synes dog at være en vis ensartethed.

Bortset fra det ganske tynde overfladelag, der vil være uden praktisk betydning, viser profilet sjældent tungsandslag på den ydre strandbred. På mellemstranden er der ofte betydelige områder med tungsand. Det findes i profilet dels i ensartede, m $\varnothing$ rke lag af varierende mægtighed (fra få $\mathrm{mm} \mathrm{og} \mathrm{op} \mathrm{til} 5 \mathrm{~cm}$ eller mere) (se tavle II, fig. 1) og med en tungsandskoncentration der ofte er over $90 \%$ og med et stort indhold af de tunge, sorte malmmineraler, dels i lagdelte tungsandskoncentrater, hvor tynde mørkere lag veksler med tynde lysere lag (se tavle IV, fig. 1). Sandet i disse lagdelte koncentrater har ofte et højt indhold af tungsand $(70-80 \%)$, men dette har et lavere indhold af de tunge sorte malmmineraler. På mellemstranden finder man sjældent tungsandskoncentrater til st $\varnothing$ rre dybde end $20-30 \mathrm{~cm}$ under overfladen, og da meget almindeligt med nogle mørke, sammenhængende bånd og derimellem det lagdelte tungsand.

På den høje strand er tungsandet ofte mest udbredt, og her finder man de sværeste lag af de gode, mørke koncentrater, i mange tilfælde aflejret helt op ad klintfoden, og hvor denne består af flyvesand da ofte overlejret af et betydeligt lag nedskredet flyvesand. Ind imellem de gode lag findes mindre koncentreret, lagdelt tungsand.

Hvor man har en bred strand, finder man ofte profiler, hvori man kan følge et eller to sorte koncentrerede lag helt fra klintfoden og ud på mellemstranden, og sådanne lag kan være sammenhængende i en bredde på 10-20 m eller mere ud fra klinten. I de fleste tilfælde har de koncentrerede mørke lag den største mægtighed inde ved klintfoden og aftager udefter. Under visse forhold kan man også på mellemstranden have ret brede bælter på langs ad kysten med koncentrerede lag af ensartet mægtighed og med mellemliggende lag af lagdelt tungsand.

Som det vil fremgå af de efterfølgende beskrivelser af tungsandsforekomster, optræder disse i mange variationer. Under visse forhold finder man flere $\mathrm{km}$ strand, hvor den фvre strand næsten overalt er mørk af tungsand, der mange steder breder sig ud på mellemstranden, og hvor man i profil finder op til 20-30 cm tungsand, for en stor del aflejret som tynde lag, så profilet optræder som meget fine striber, men også i mange tilfælde med et eller to gode lag af sort koncentreret tungsand i varierende dybde. På andre områder finder man overvejende kun den lagdelte type og mest i svage koncentrationer, og da næsten altid rødligt, undertiden grønligt på grund af et relativt stort indhold af granat og andre silikater.

Efter en periode med roligt vejr og uden høj vandstand udviskes det mørke præg i mange tilfælde, idet der ved sandfygning aflejres et lag 
lyst sand over det m $\phi$ rke tungsandskoncentrat, hvorfor man ved undersøgelse af kyster ikke ud fra overfladens udseende altid får at vide, om der findes koncentrater; der må foretages et meget stort antal prøvegravninger.

Foruden de større samlede forekomster af tungsand, hvor man næsten altid finder såvel sorte, stærkt koncentrerede og tunge lag som lysere, rødligt og da meget ofte lagdelt tungsand med betydeligt indhold, findes der lokalt mange steder mindre ansamlinger af tungsand.

\section{Recognosceringernes hovedresultater.}

Efter de hidtil foretagne undersøgelser er der ingen tvivl om, at de st $\varnothing$ rste og bedste tungsandsforekomster optræder i Vendsyssel, hvor de på østkysten findes fra Skagen i nord og til Hulsig i syd og på vestkysten særlig findes på strækningen Kandestederne-Skiveren, nord for den $\varnothing$ stlige del af Uggerby Plantage, og fra L $\varnothing$ nstrup i syd og til Liver $\AA$ i nord. Strækningen fra Hulsig på Kattegatskysten, rundt om Skagen og på Vesterhavskysten til Lønstrup i syd er gennemvandret, mange af strækningerne endda flere gange.

Af andre områder med tungsand i så store mængder, at det på nuværende tidspunkt vil være naturligt at tænke på udnyttelse, har man flere steder på strækningen Harboøre til et par km syd for Fjaltring, særlig fra det gamle digebrud syd for Mærsk kro og i nord omtrent til Fjaltring kirke. Endvidere er der på Holmsland Klit, særlig omkring Lyngvig og fra Hvide Sande og 3-4 km i syd flere områder med gode koneentrater og i sådanne mængder, at det vil kunne lade sig udnytte. Ved Liseleje findes under visse forhold ret store mængder af tungsand.

\section{Beskrivelse af forekomsterne.}

Den følgende redeg $\varnothing$ relse for forholdene på de undersøgte kyststrækninger behandler først forekomsterne på Jyllands vestkyst, derefter på $\phi$ stkysten og фerne. Ved omtalen af de store forekomster er sk $\phi$ n over tungsandsmængder og -kvalitet anf $\varnothing$ rt. På grund af, at der med ændringer i vejrforhold kan ske ændringer i forekomsternes st $\varnothing$ rrelse, koncentrationsgrad og sammensætning, kan de iagttagne forhold kun tillægges fuld gyldighed for observationstidspunktet, som derfor er anf $\phi r t$ i beskrivelserne.

Jyllands vestkyst.

Grenen-Redningsvejen.

Sammen med Gunnar Larsen d. 4/8 1956. I $\varnothing$ vrigt flere bes $\varnothing$ g og helt gennemgået d. 18/11 1958. Meget flad, bred strand nord for klitterne. På over- 
fladen ses spredt lidt tungsand. Profiler viser flere steder tynde, mørke sandlag, men disse er meget underordnede. Vil næppe kunne få praktisk betydning, da malmindholdet er meget lavt.

\section{Redningsvejen-Industribyen.}

Gennemgået 18/11 1958. I $\varnothing$ st nærmest som ovenfor nævnt. Midt på etapen findes ind imellem tynde overfladelag af tungsand. Lidt længere i SV ret betydelige mængder af tungsand $\mathrm{i}$ et bælte mellem stenvolde. Ret groft og hviler på grus. Længst i syd grus og stenvolde. Imellem gruset flere steder en del tungsand. Under gunstige forhold kan der sikkert i den sydlige del dannes koncentrater af tungsand, der kan udnyttes.

\section{Industribyen-Gl. Skagen.}

18/11 1958. Fra nedk $\varnothing$ rsel til stranden og til Højen fyr mindre mængder tungsand på den høje strand ind mod klinten; ligger ret varierende, blandet med sten. Ca. $1 \mathrm{~km} \mathrm{~N}$ for Gl. Skagen $\mathrm{i}$ en lille bugt mindre mængder af ret gode koncentrater af tungsand. Lagtykkelse op til 5-6 $\mathrm{cm}$. Ret stærkt eroderet og nogle steder overlejret af $25-30 \mathrm{~cm}$ lyst sand. Lige op mod klinten flere steder stærkt eroderet, grusblandet tungsandslag. Der skulle forventes muligheder for udnyttelse nogle steder på strækningen under gunstige forhold.

\section{Gl. Skagen-Kandestederne.}

Gennemvandret d. 17/11 1958. Ved Gl. Skagen og det første stykke i syd overvejende groft sand uden tungsand af betydning. Omkring midten af etapen (ved Gl. Redningsvej) ret gode koncentrater på høj strand. Der fandtes dels et stærkt koncentreret lag på nogle $\mathrm{cm}$, nogle steder overlejret af lyst sand, dels lagdelt tungsand af mellemkvalitet. Længere i syd kun svage koncentrater på høj strand af lagdelt tungsand. De to $\mathrm{km}$ nord for nedk $\varnothing$ rsel ved Kandestederne kun tungsand i ganske underordnede mængder.

Under gunstige forhold må der ventes udnyttelsesmuligheder omkring den gamle redningsvej.

\section{Kandestederne-Skiveren.}

Strækningen gennemk $\phi$ rt med bil august 1956 sammen med Gunnar Larsen. De nordligste $2-3 \mathrm{~km}$ bes $\varnothing$ gt flere gange. Hele strækningen gennemvandret april 1959 .

Lige syd for nedk $\varnothing$ rsel ved Kandestederne betydelige mængder af lagdelt tungsand på mellemstrand; magtighed mange steder $5-15 \mathrm{~cm}$. Indholdet af malmmineraler lavt.

Fra $1 \mathrm{~km}$ syd for nedkørsel ved Kandestederne til Ny Studeli Rende er der meget bred strand; $10-15 \mathrm{~m}$ ud fra den tilgroede klint delvis vegetationsdækket. Nedenfor et meget fugtigt bælte med r $\varnothing$ d, okkerholdig mudret overflade, og derefter tør, sandet mellemstrand. Tungsandsaflejringer meget udbredt $\mathrm{i}$ en bredde på op til $20 \mathrm{~m}$ begyndende i vegetationsbæltet neden for klinten og videre gennem det fugtige bælte. Sådanne forhold ret ensartet på en strækning af et par $\mathrm{km}$, idet det fugtige bælte dog ebber ud i den sydlige del. De $\phi$ verste $5-10 \mathrm{~cm}$ ret stærkt koncentreret tungsand, nedad svagere koncentreret, mere udpræget lagdelt. Samlet mægtighed op til $20 \mathrm{~cm}$ og mere. 
Fra Ny Studeli Rende og godt $1 \mathrm{~km}$ frem er der på stranden aflejret en ny, ret lav klit parallelt med klinten og ca. $50 \mathrm{~m}$ fra denne. Der findes her på den høje strand ind til den ny klit et meget udbredt lag af tungsand, der de fleste steder er overlejret af lyst sand. Syd herfor, ud for Raabjerg Stene, findes fint overfladelag af tungsand i en bredde af $6-10 \mathrm{~m}$. Det $\varnothing v e r s t e$ lag godt koncentreret, nedad den lagdelte type. Efter at Raabjerg Stene var passeret kun ganske lidt tungsand. Syd for Raabjerg Stene (Slaasbakke) ret kraftig nedbrydning i klinten.

Mængder: På strækningen 4-5 $\mathrm{km}$ med betydelige mængder tungsand. Mængden kan vel anslås til omkring 10.000 tons.

Kvalitet: Tungsandskoncentrationen ofte meget høj, 80-90\%. Kun ringe indhold af magnetit og moderat indhold af hæmatitholdig ilmenit. Zirkonindholdet (2 prøver) ca. $10 \%$.

Dannelsesmuligheder: Muligheder for tilf $\varnothing$ rsel af nyt materiale fra klintnedbrydning i syd.

\section{Skiveren-Tværsted.}

Strækningen gennemk $\phi r t$ med bil august 1956 sammen med Gunnar Larsen, og delvis kørt og gået $\mathrm{i}$ april 1959. Kun ganske lidt tungsand. Næppe muligheder for at der dannes koncentrater, der kan have praktisk betydning.

Omkring Uggerby Ås udløb findes store mængder af sand, men der er ikke iagttaget tungsand af betydning.

\section{Uggerby Å-Tolstrupvejen.}

Nord for østlige del af Uggerby Plantage fra et par hundrede meter vest for sogneskellet (Tværsted-Uggerby) og til et par hundrede $m$ øst for vejen Tolstrup-stranden ret god tungsandsforekomst på en strækning af ca. $1,5 \mathrm{~km}$. (April 1959). Særlig godt i det midterste parti, hvor der bag sandstranden findes et lavt, temmelig bredt forland. Tungsandet findes mest på overgangen mellem strand og forland med begyndende tilgroning $\mathrm{i}$ et bælte, der også er rigt på drivgods.

Mængder: Efter den ret hurtige gennemgang af arealet anslås mængden til omkring 2000 tons af ret gode koncentrater.

Kvalitet: Der foreligger ingen petrografisk analyse. Ved magnetsortering af en prøve fandtes i tungsandet ca. $40 \%$ malmsand, deraf $1 / 3$ magnetit.

Dannelsesmuligheder: Gode muligheder for tilførsler af tungsand fra nedbrydning $\mathrm{i}$ vest (sml. side 25 ).

\section{Tolstrupvejen-Hirtshals.}

April 1959. Nord for Uggerby Plantage intet tungsand af betydning. Kun antydning af tynde lag $\mathrm{i}$ det lyse sand. Ret stærk nedbrydning af lav klint (sml. side 25). Omkring Kjul §̊ antydning af overfladelag, men vil næppe få interesse. Nærmere ind mod Hirtshals bred tilsandingsstrand uden tungsand.

\section{Hirtshals-Tornby Klit-Liver Å.}

Nedenfor klinterne ved Hirtshals ganske lokalt mindre ansamlinger af tungsand. Uden interesse. Syd for Hirtshals ned mod Tornbyvejen overvejende groft sand, der er meget fattig på tungsand. Lidt antydning af tungsand omkring Tornbyvejen. I syd ned mod Liver Å tynde lag af tungsand på 
overfladen. Under gunstige forhold skulle der være muligheder for bedre koncentrater.

\section{Liver Å-Sфnderlevvejen.}

August 1956 gennemgået den sydligste del af området sammen med Gunnar Larsen. Senere bes $\varnothing \mathrm{gt}$ lokaliteten mange gange; sidste gang januar 1959. Det er den mest malmrige tungsandsforekomst, der er iagttaget. Den høje strand og mellemstranden er på den sydlige halvdel af strækningen altid mørk, og efter at være overskyllet af b $\varnothing$ lgerne er overfladen glinsende sort. I et gravet profil på stranden vil man da øverst finde et ensartet lag af sort, meget tungt tungsand. Mægtigheden af dette lag er ofte mellem 5 og $10 \mathrm{~cm}$, lige ind under klinten undertiden endnu mere. Derunder findes fint lagdelt tungsand, og i dette ofte endnu et eller to lag af varierende mægtighed af det ensartede mørke sand (se tavle VII, fig. $1 \& 2$ ). - Ved et bes $\phi g$ på stranden d. 25/1 1956 lige efter en storm var der et sådant meget fint sort glinsende overfladelag på mellem $1 \mathrm{og} 2 \mathrm{~km}$ strandbred og nogle steder med en bredde på op til $20 \mathrm{~m}$. Dette koncentrerede lag findes stadig flere steder, men er nu overdækket af nye lag i varierende koncentrationer. Man får indtryk af, at der her foregår en tilsanding, idet vegetationen breder sig fra den lave klint, der flere steder ser ud til at bestả af unge klitter, og ud på stranden. Klitterne lige bag klinten indeholder ret betydelige mængder tungsand, og ved særlig kraftigt højvande kan b $\varnothing$ lgerne udvaske dette allerede ret koncentrerede flyvesand. Når strandbredden har været $t \varnothing r$ i en periode, kan man konstatere, at der sker en omlejring og fjernelse af tungsand ved vindens hjælp. Flere steder aflejres der småsten (op til ægstore sten) sammen med tungsandet. Når tungsandet blæser bort, ser man disse spredte sten ligge på en sandkegle, hævet nogle $\mathrm{cm}$ op over sandoverfladen. Ved denne forekomst er det også meget iøjnefaldende, hvordan sandet i tørre perioder fanges af ris og andre hindringer på stranden. Ved et kortvarigt højvande koncentreres sådanne mindre ansamlinger, og derved kan man lokalt få sværere lag af tungsand.

Mængder: På den omtalte strækning må det anslås, at der på 2-3 km findes mellem 5 og 10.000 tons stærkt koncentreret tungsand.

Kvalitet: Meget store dele af tungsandet indeholder over $90 \%$ tungmineraler. Der findes lag på $5-10 \mathrm{~cm}$, hvor indholdet af tungmineraler praktisk taget er 100. Indholdet af malmmineraler ligger på over $50 \%$, omtrent ligeligt fordelt på magnetit og hæmatitholdigt ilmenit. Indholdet af zirkon synes at ligge omkring $5 \%$.

Dannelsesmuligheder: Fra nedbrydningsklinter i syd (eventuelt også helt nede fra Lønstrup klint) skulle der være ret gode muligheder for tilførsel af mere tungsand.

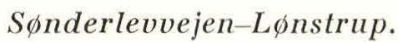

August 1956 sammen med Gunnar Larsen gjort iagttagelser på den nordligste og sydligste del. Siden flere bes $\emptyset \mathrm{g}$ på strækningen, mest på den nordlige del til Knolde Bæk og syd på ved Lønstrup by. Hele strækningen gennemvandret november 1958 og januar 1959. Mængde og udseende af tungsandskoncentrater varierer stærkt fra tid til anden. Under visse forhold findes der ind mod klinten gode koncentrater af tungsand, til andre tider findes på mellemstranden ret gode overfladelag over lagdelt tungsand, til andre tider kun lagdelt tungsand, ofte med ret god koncentration og flere steder 
overlejret af lyst sand. Særlig udbredt er tungsandet i den nordlige del i tilslutning til den ovenfor omtalte strækning, omkring Knolde Bæk og omkring Hunderup bæk. Der fandtes her gode overfladelag af tungsand, op til $5 \mathrm{~cm}$ og $\mathrm{i}$ en bredde af 5 til $15 \mathrm{~m}$. Nord for Lønstrup er enkelte gange nedenfor Lønstrup klint iagttaget gode koncentrater, ved andre bes $\emptyset \mathrm{g}$ har der ikke været noget. Sadanne koncentrater må skylles bort under stærkt højvande, og midlertidig bliver der også begravet en del under nedskridninger fra klinten.

Mængder: Ud fra de spredte iagttagelser og med de store variationer er det meget vanskeligt at skønne om mængder, men der må regnes med, at der, når de gunstige perioder udnyttes, kan fjernes mindst 5.000 tons gode koncentrater af tungsand på strækningen.

Kvalitet: Koncentrationen af tungsand vil knap være så stor som i tungsandet nord for Sønderlevvejen. Tungsandet indeholder godt $20 \%$ magnetit og omkring $25 \%$ hæmatitholdigt ilmenit. Der er ikke foretaget zirkonbestemmelser i prøver fra denne strækning, men det vil nok være omkring $5 \%$ som i sandet fra det tilgrænsende areal i nord.

Dannelsesmuligheder. Der skulle ventes gode muligheder for nydannelse ved sortering af nedbrydningsmateriale fra Lønstrup Klint, idet kyststrømmen her er nordlig.

\section{Lønstrup Klint.}

Det er allerede nævnt, at der ved Lønstrup Klint nord for Lønstrup under visse forhold findes mindre mængder af ret gode koncentrater af tungsand nedenfor klinten. Lige syd for »Havnen « har man Vildbækken, der har skåret sig ned gennem klinten. I denne og langs denne findes meget betydelige mængder tungsand. Når der her samler sig så store mængder, vil jeg mene, at hovedårsagen er, at bækvandet fanger en hel del flyvesand, og at det lette sand af bækvandet føres med ud $\mathrm{i}$ havet, mens det tunge sand bliver tilbage i bæklejet, der alt efter hindringerne ofte flytter sig noget.

I $\varnothing$ vrigt er der kun foretaget enkelte iagttagelser på stranden nedenfor Lønstrup Klint, således på et stykke syd for Vildbækken, omkring Rubjerg og ved Nørre Lyngby. Ved disse steder er der ikke iagttaget tungsand af betydning. Af lokalkendte folk er det oplyst, at der nedenfor klinten i forbindelse med væld og udsivende vand fra klinten fandtes ret betydelige mængder af sort, tungt sand som ved Vildbækken. Har endnu ikke haft lejlighed til at unders $\varnothing$ ge forholdet nærmere.

\section{Løkken-Blokhus.}

Gennemkørt stranden med bil sammen med Gunnar Larsen august 1956 og stedvis foretaget unders $\varnothing$ gelser uden at træffe tungsand af interesse.

\section{Blokhus-Tyborøn.}

På denne strækning er der kun foretaget afstikkere til kysten i august 1956 sammen med Gunnar Larsen og endvidere er der senere foretaget spredte iagttagelser. Ved Rødhus fandtes lidt tungsand, og der skulle være muligheder for dannelse af koncentrater. Fra Tranum og til Agger er der aflagt besøg på stranden en halv snes steder, og overalt har strandbredden overvejende bestået af sten og grus; der er ikke iagttaget koncentrater af tung- 
sand af betydning. Det kan dog ikke uden nærmere unders $\emptyset$ gelser fastslås, at der ikke findes tungsand på denne strækning. Ved Agger blev aflagt bes $\emptyset \mathrm{g}$ juli 1958. Der var flere steder tilløb til koncentrationer syd for Agger, men ikke i sådanne mængder, at det kunne udnyttes.

\section{Tyborøn-Langer Huse (Harboøre).}

Juli 1956 var der ved Tyborøn mindre mængder tungsand mellem høfderne. Næppe mulighed for udnyttelse. Ved Langer Huse overvejende grus og sten. Flere steder i mellemrummene mellem gruset meget tungsand. Enkelte steder var der mindre ansamlinger af tungsand ovenpå grus og i lavninger mellem grusvolde. Tungsandet var her ret groft. Senere bes $\emptyset \mathrm{g}$ har vist nærmest samme forhold. Under gunstige forhold skulle der være muligheder for, at der dannes større forekomster af tungsand. Mængder vil det ikke være muligt at udtale sig om på foreliggende grundlag.

Kvalitet: Det grove sand vil næppe give så rene koncentrater. Sandet indeholder en del magnetit og ret betydelige mængder af hæmatitholdigt ilmenit.

Dannelsesmuligheder: Under gunstige forhold muligheder for bedre koncentrering af tungsandet. Man kan vel ved opkastningen af de store strandvolde af sten og grus regne med, at der sker nogen formaling af materialet og derved også tilførsel af tungt mineralsand.

\section{Langer Huse-nordenden af Ferring S $\phi$.}

Samlet gennemgang januar 1959. Tidligere spredte iagttagelser. I nord ud for Harboøre sten og grusvolde som omtalt ovenfor. Sydligere overvejende sandstrand. Omkring Nr. Vrist en del tungsand dog mest i tynde lag (2-3 $\mathrm{cm})$. Længere mod syd mere spredt tungsand på overfladen og nogle steder lagdelt tungsand med svage koncentrationer. Under gunstige forhold sikkert mulighed for udnyttelse.

\section{Ferring $S \phi-F$ jaltring.}

Enkelte iagttagelser juli 1956. Nedenfor klinten ved fyret fandtes ikke nævneværdigt tungsand, ligesom der heller ikke ved Trans kirke var tungsand af betydning, og det samme var tilfældet på stranden indtil Fjaltring kirke.

\section{Fjaltring-Fjordshule.}

Juni og oktober 1956 og flere gange senere, sidste gang januar 1959. Der findes her på stranden fra lidt syd for Fjaltring kirke og til Fjordshule betydelige forekomster af koncentreret tungsand. Forholdene varierer stærkt fra tid til anden, men på den midterste del af den ca. $2 \mathrm{~km}$ lange strækning findes der altid på den $\varnothing$ vre strandbred gode koncentrater og i mange tilfælde også på mellemstranden. For at hindre flyvesandet fra stranden i at trænge ind på det lave bagland er der bag strandbredden sat et par rækker fyrreris op til at fange sandet. Op mod disse fyrreris findes efter en storm omtrent rent tungsand, og gode koncentrater kan også findes nogle steder inde mellem risene. Ved særligt højvande må havet gå op og skylle det lette sand ud mellem risene og lade tungsandet tilbage, for på de tider, da der er nyaflejret flyvesand mellem risene, har sandet kun et lavt indhold af tungsand. 
Mængder: Ved udnyttelse under gunstige forhold vil der på den ca. $2 \mathrm{~km}$ lange strækning sikkert findes over 5.000 tons tungsand af $h \varnothing \mathrm{j}$ koncentration.

Kvalitet: Gode lag af tungsand ofte med $90 \%$ tungmineraler og i disse omkring $20 \%$ magnetit og 30-40\% hæmatitholdigt ilmenit.

Dannelsesmuligheder: Der synes her at foregå en ret betydelig nedbrydning af kysten.

\section{Bøvlingklit.}

Oktober 1956 spredte iagttagelser. Indtil Thorsminde langt overvejende sten og grusvolde på strandbredden. Imellem gruset mange steder en del tungsand, og under visse forhold findes tungsand i tynde lag over gruset og på mellemstranden. Under gunstige forhold muligvis udnyttelsesmuligheder. På tangen fra Thorsminde til Fjande kun iagttaget sten og grusvolde uden tungsand af betydning.

\section{Fjande-Søndervig.}

Oktober 1956 spredte iagttagelser langs kysten. Ved Fjande mindre forekomster af tungsand. Vest for Husby kirke en del tungsand på grusrig strand, dog i tynde lag eller svage koncentrationer. Ved Sundshuse svage koncentrationer, spredt. $2 \mathrm{~km}$ syd for Sundshuse på den høje strand 3-20 $\mathrm{cm}$ lag af nogenlunde koncentreret tungsand. $3 \mathrm{~km}$ syd for Sundshuse tynde lag af tungsand mellem sand og grus. Et par steder ud for nordenden af Nr. Stadil fjord fandtes grus og intet tungsand. Ved Kryle en del spredt tungsand, ingen steder samlet i koncentrater. Ved Hovvig lignende forhold 1956. I juli 1958 mindre mængder af nogenlunde koncentrater. Ved Søndervig kun lidt og spredt tungsand. Under gunstige forhold vil der sikkert på strækningen findes gode koncentrater i sådanne mængder, at det kan have interesse til udnyttelse.

\section{Søndervig-Hvide Sande.}

April 1956 første gang iagttagelser ved Søndervig og Nr. Lyngvig fyr. Siden jævnlige bes $\emptyset$ g ved Lyngvig. Hele strækningen samlet gennemvandret januar 1959. Omkring Søndervig kun lidt tungsand. Ca. $1 \mathrm{~km}$ syd for S $\varnothing \mathrm{n}-$ dervig på en strækning af $1 \mathrm{~km}$ ret meget tungsand af god mellemkvalitet, dels som overfladelag, dels dækket af lyst sand. Derpá fandtes en strækning, hvor stranden var ret rig på grus og uden tungsand. Syd for Trenatbjerg atter mindre forekomster af tungsand. På stranden nedenfor Nr. Lyngvig fyr har forholdene varieret meget. I perioder har der været ret betydelige mængder af gode tungsandskoncentrater, i andre perioder har tungsandet været spredt på den brede strand og i klitter ind under klinten. De bedste koncentrater har snart været det ene sted, snart det andet, men der har altid været tungsand at finde på stranden nedenfor Lyngvig fyr og et par $\mathrm{km}$ i syd. I januar 1959 gode forekomster fra omkring $1 \mathrm{~km}$ syd for fyret og et par km i syd. Der fandtes således på mellemstranden nogle områder med helt frisk aflejret tungsand med lag på op til $5-10 \mathrm{~cm}$, $\emptyset$ verst ret ensartet og godt koncentreret, nedad af den lagdelte, mindre koncentrerede type. På de sidste par $\mathrm{km}$ ned mod Hvide Sande fandtes ingen koncentrater af tungsand, selv om det var tydeligt at se på sandoverfladen, at der var lidt tungsand til stede. På denne strækning er der (vel nok siden udbygningen 
af havnen) sket en tilsanding. Strandbredden bliver bredere i syd, og der opbygges nye klitrækker uden for den gamle klitrække.

Mængder: Der fandtes til forskellige tider meget varierende mængder af gode tungsandskoncentrater, men noget var der altid. Udnyttes de gunstigste perioder, vil det sikkert være muligt på denne strækning at tage nogle tusinde tons tungsand.

Kvalitet: Der kan til tider findes betydelige mængder af tungsand med omkring $90 \%$ tungmineraler og langt mere med mindre koncentration. Magnetitindholdet er ganske ringe. Indholdet af hæmatitholdigt ilmenit (magnetsortering) 20-25\%. Indholdet af zirkon i tungsand var i to prøver henholdsvis 3 og $11 \%$, altså meget varierende.

Dannelsesmuligheder: Sandsynligvis ved nedbrydning af kysten.

\section{Hvide Sande-Nymindegab.}

Kun foretaget spredte iagttagelser 1956-1958. Lige syd for Hvide Sande er ved et par bes $\varnothing$ g ikke iagttaget tungsand af betydning. Stranden nedenfor Aargab mejeri er besøgt flere gange, første gang oktober 1956. Der fandtes da gode koncentrater af tungsand, der på det tidspunkt tydeligt var under nedbrydning, idet havvand, der havde overskyllet en ret høj sandrevle pả den ydre strand, når det strømmede tilbage, på en strækning løb langs klinten og skar sig igennem aflejringer af tungsand. Denne "afløbsrende « skar sig $1 / 4 \mathrm{~m}$ ned i sandet, og $i$ et profil på flere hundrede meter kunne man følge et tungsandslag af en mægtighed på op til $15 \mathrm{~cm}$. Det nedbrudte tungsand blev spredt på strandbredden, når vandet skyllede tilbage $\mathrm{i}$ havet. Senere besøg i dette område viste meget varierende forhold; i almindelighed fandtes der en del tungsandskoncentrater i området. Spredte iagttagelser syd på til Nymindegab viste ikke tungsand af betydning.

\section{Nymindegab-Blåvand.}

Der er på denne strækning kun foretaget spredte undersøgelser af strandbredden ved Henne, Vejers og omkring Blåvand samt enkelte mellemstationer. Som overalt ved kysterne er der iagttaget tungsand, men i de undersøgte områder var der ingen steder på de tidspunkter, hvor besøgene fandt sted, tungsand i sådanne mængder og koncentrater, at det kunne anses for at have praktisk betydning.

Syd for Blåvand er der heller ikke bemærket tungsand i mængder, der har praktisk interesse.

Jy llands $\phi$ st ky st.

Grenen-Skagen.

Overvejende sten- og grusvolde. Lokalt lidt tungsand, men uden praktisk betydning.

\section{Skagen-Hulsig.}

Området første gang iagttaget sammen med Gunnar Larsen august 1956. Fra Klitgaarden og ca. $1 \mathrm{~km}$ i syd betydelige mængder af tungsand. Sandet lå som ret svære lag dels af ensartet, sort, koncentreret tungsand, dels af lagdelt tungsand. Ind under klinten fandtes klitter, der lagvis var rige på tungsand. Sydligere, udfor Sandmilen, også betydelige mængder tungsand. Lige nord for Hulsig også tungsand, dog mindre mængder. 
Senere er forekomsten besøgt mange gange ved forskellige årstider, særlig den nordlige del af området. Altid store mængder af tungsand, ofte som gode overfladelag og med stor mægtighed. De mørke ensartede koncentrater sjældne; overvejende rødlig og grønlig farve. Selv ved ret lav vandstand tungsandslag helt ud til vandet. Lige efter at bølgerne har overskyllet strandbredden, er dennes overflade overalt helt mørk. Efter længere tids lav vandstand og blæst kan den overvejende del af strandbredden være ret lys, idet det mørke sand er overlejret af lyst, let strandsand.

7/11 1958 gennemvandret stranden fra Klitgaarden til Hulsig (Tranesteder). Fra Klitgaarden i nord og til Stokrenden mørk, r $\varnothing$ dlig strandbred. I nord de fineste koncentrationer af tungsand, mange steder med lagtykkelse på $20 \mathrm{~cm}$, undertiden mere. Det gode tungsandslag udgik fra klitfoden og havde en bredde på 5-10 m, undertiden mere. I bølgeslagsområdet (ret lav vandstand) kun svage koncentrationer af tungsand. Det $\varnothing$ verste lag det mørkeste og mest koncentrerede, og ved gravning fandtes flere steder i forskellig dybde gode koncentrater. Ved foden af klinten flere steder klitter med ret god koncentration af tungsand, der ved højvande vil udvaskes og danne nye tungsandslag.

Syd for Stokrenden, ud for Sandmilen, var stranden mere lys, og der fandtes ikke konstante, gode lag af tungsand. Nogle steder i 10-15 cm dybde fine koncentrater. Store mængder af lagdelt tungsand af mellemkvalitet. Under gunstige forhold må der dannes betydelige mængder af gode koncentrater på overfladen. Stranden blev gennemgået til Tranestederne, og der var stadig en del tungsand, dog ikke som et sammenhæengende lag som i nord.

Mængder: Forekomstens længde ca. $6 \mathrm{~km}$. I nord 2-3 tons tungsand pr. lǿbende $\mathrm{m}$ strand, i syd mindre. Mængden blev der anslået til ca. 10.000 tons.

Kvalitet: Tungsandet meget fattigt på magnetit og med moderat indhold af hæmatitholdigt ilmenit. Zirkonindholdet omkring $5 \%$. Stort indhold af granater og grønne silikater.

Dannelsesmuligheder: Syd for Klitgaarden kraftig nedbrydning af overvejende flyvesand, ret rigt på tungsand. Med vestlig vind tilføres der sand inde fra land. I vindbrud i klitterne ses, at flyvesandet er relativt rigt på tungsand.

\section{Hulsig-Limfjorden.}

August 1956, ca 10 iagttagelser sammen med Gunnar Larsen. Overvejende sandstrand, mange steder meget lavvandet. Ganske underordnede mængder af tungsand.

\section{Fra Limfjorden til Mariager Fjord.}

August 1956, ca 10 iagttagelser sammen med Gunnar Larsen. Overvejende lavvandet kyst, flere steder med tendens til tilgroning. Intet tungsand.

\section{Helgenæs.}

August 1956, Gunnar Larsen. Små ansamlinger i sandflader mellem stenene.

Rude Strand.

Som Helgenæs. 
Saksild Strand.

August 1956, Gunnar Larsen. Tynde striber med høj koncentration i bølgeslagslinien, se tavle II, fig. 2.

Ved Hov og Gyllingnæs.

August 1957. Intet tungsand.

Snaptun og Juelsminde.

Januar 1959, Kun ganske underordnede mængder af tungsand.

Hejlsminde og Felsbæk.

Januar 1959. Intet tungsand.

F y n.

Lillebæltkysten.

Ved Strib og Røgle små ansamlinger af godt koncentreret tungsand.

Odense Fjord.

Ved Lang $\varnothing$ ret gode tungsandskoncentrater, men kun i mindre mængde.

Helnæs og Falsled.

Ikke tungsand af betydning.

Båring Vig.

Tungsand ganske underordnet.

Storebæltskysten.

På Hindsholm, i Kertemindebugten, ved Risinge og Nordenhuse små ansamlinger af tungsand, der næppe har praktisk betydning.

$\mathrm{S} \mathrm{j} æ 11$ a n d.

Liseleje-Tisvildeleje.

Bes $\varnothing$ gtes første gang april 1956 på den første efters $\varnothing$ gning efter tungsand. Gode koncentrater på den høje strand nedenfor byen og omkring havnen. I sommeren 1956 var tungsandet mere spredt. December 1958 var den høje strand nærmest sort af tungsand på en strækning af $2-3 \mathrm{~km}$ fra klinten i vest nedenfor Liseleje og Asserbo plantage. De fleste steder havde tungsandslaget kun en mægtighed på omkring $1 \mathrm{~cm}$, enkelte steder lokale ansamlinger med $5 \mathrm{~cm}$ eller mere. Maj 1959 gennemvandret stranden fra Liseleje til Tisvildeleje. På grund af sandfygning var der da næsten overalt et ensartet, gråligt overfladelag med lidt tungsand. Ved gravning fandtes mange steder øst for Liseleje på den høje strand og på skråflade op mod lav nedbrydningsklint et ret koncentreret lag tungsand med en mægtighed, der sjældent var over ca. $5 \mathrm{~cm}$. I klinten sås tynde vandrette striber af tungsand.

Forekomsten ebbede ud omtrent halvvejs mellem Liseleje og Tisvildeleje, og videre frem var der heller ikke nedbrydning i klinten, den var snarere under tilgroning. Iagttagelserne her tyder på, at tungsandet på dette sted kommer fra nedbrydning af den gamle, marine aflejring (V. Milthens, 1935) og hovedsagelig aflejres på stranden umiddelbart neden for denne. Det 
synes, som om de dannede koncentrater af tungsand ret hurtigt eroderes og spredes.

Mængde: Under gunstige forhold, d. v. s. lige efter en storm, der har ført til dannelse af gode koncentrater, skulle der vel være mulighed for opsamling af 1000 à 2000 tons godt koncentreret tungsand.

Kvalitet: Friske overfladelag vil let indeholde $90 \%$ tungsand med omkring $60 \%$ malmsand, deraf omtrent halvdelen god magnetit, resten hæmatitholdigt ilmenit. De petrografiske analyser viser, at sandet her har et relativt lavt indhold af zirkon, idet dette kun ligger på omkring $2 \%$.

\section{Rågeleje.}

Mindre forekomster af tungsand, der er nærmere undersøgt af Gunnar Larsen.

Spredte undersøgelser andre steder på Nordsjællands kyst har ikke afsløret tungsand i større mængder, men lokalt kan der findes mindre, ret gode koncentrerede ansamlinger. Dette gælder også Nordvestsjællands Kattegatkyst (Nykøbing Nordstrand-Klintebjerg).

$L \mathscr{L} \phi$.

April 1959. Den sydlige kyst meget lavvandet, og der vil næppe der være muligheder for dannelse af tungsandskoncentrater i mængder, der har nogen interesse.

Kysten blev gennemvandret fra Bløden Hale i $\varnothing$ st nord om $\emptyset$ en til syd for Vester $\varnothing$ kirke i sydvest. Der findes flere steder lidt tungsand, men næppe i sådanne mængder og koncentrationer, at det vil fă interesse i første omgang. Omkring Syrodde således nogle steder lagdelt tungsand og tynde mørke overfladelag. Øst for Østerby redningsstation lidt bedre koncentrater, men kun i mindre mængder. Mellem Kridemands Dal og Horneks Odde findes lagdelt tungsand i nogenlunde koncentrationer på stranden. Forekomstens længde 1 à $2 \mathrm{~km}$, bredde op til 4-5 m, tykkelse op til 5-6 $\mathrm{cm}$, den $\phi$ verste $\mathrm{cm}$ med ret god koncentration. Klitterne bag stranden bærer præg af tungsand. SV for Horneks Odde og til Storedal flere steder lignende forhold, men ikke så konstant og med noget sværere koncentration af tungsand. Endvidere fandtes lige nord for Vester $\varnothing$ havn og kirke enkelte steder tilløb til lagdelt tungsand, men uden praktisk betydning.

Mængder: Vanskeligt at bedømme. Godt tungsand findes egentlig slet ikke.

Kvalitet: Indholdet af tungmineraler i prøver af de bedste lag lå på mellem 40 og $50 \%$. Tungsandet indeholdt kun spor af magnetit og havde et lavt indhold af ilmenit. Der er ikke undersøgt for indhold af zirkon.

Andre om råder.

Foruden de i det foregående nævnte lokaliteter, der er besøgt for at skaffe en orientering om tungsandets udbredelse, ved vi på grundlag af prøver i D. G. U.'s samling og mere tilfældige iagttagelser fra forskellige af D. G. U.'s medarbejdere m. m., at der findes tungsand ved Karrebæksminde, ved Rødbyhavn, på Falsters NV kyst ved Vaalse Vesterskov og på østkysten, og ved Bøstrup Strand på Langeland, men efter de foreliggende oplysninger drejer det sig kun om mindre mængder. Fra Bornholm kender vi tungsand fra Dueodde, og desuden er der af fiskeribiolog dr. phil. Aage Jensen indleveret en mindre prøve tungsand fra Bornholms sydkyst ved Arnager. 
Af foranstảende oversigt over iagttagelser af tungsand ved vore kyster fremgår, at der endnu er lange kyststrækninger, der ikke er gennemgået, og der vil således være muligheder for, at der kan findes flere områder med koncentrationer af tungsand. De helt store forekomster er der dog næppe stor sandsynlighed for at finde uden for de gennemgående områder, men kun en systematisk unders $\varnothing$ gelse af kysten kan give sikre oplysninger. Man må desuden regne med, at ekstreme storme i forbindelse med h $\varnothing$ jvande kan give anledning til nydannelser. Endvidere har erfaringen lært os, at sommeren er en meget dårlig tid for unders $\emptyset$ gelser, idet sandflugten i den tørre tid ofte giver det mørke sand et overtræk af lyst sand, således at en unders $\emptyset$ gelse kræver langt st $\varnothing$ rre gravearbejde. Dertil kommer, at man meget vanskeligt i tørre sandlag kan konstatere lagenes mægtighed; det hele skrider sammen, når man graver et profil.

En systematisk efters $\varnothing$ gning af tungsand ved vore kyster vil dog ikke kræve en gennemgang af alle kyster, idet der dels findes betydelige kyststrækninger med en meget bred forstrand med lavt vand, der hindrer b $\varnothing$ lgerne $\mathrm{i}$ at nå ind til kysten og sortere sandet, og dels findes der lange kyststrækninger uden udpræget sandstrand. 


\section{TUNGSANDSAFLEJRINGERNES DANNELSE}

Ud fra det kendskab man har fået til tungsandet og dets udbredelse gennem de indtil nu foretagne unders $\emptyset$ gelser, har man mulighed for at drage visse slutninger om tungsandets dannelse. En nøje vurdering af de geologiske forhold har en betydelig praktisk værdi, da den vil være af betydning for en bedømmelse af, 1) hvilke muligheder man har for tilførsel af nyt tungsand på stranden, 2) hvilke sandsynligheder der er for, at det tungsand, der findes i svagere koncentrationer på stranden, ved omlejring samles i bedre koncentrationer, 3) i hvor stor udstrækning tungsandet ved naturens indgreb fjernes fra de allerede bestående koncentrater, og 4) hvorvidt der regionalt er en udpræget forskel på forholdet mellem de enkelte tungmineraler i tungsandet.

\section{Koncentrationsprocessen på stranden.}

Der kan næppe være tvivl om, at en betydelig del af det tungsand, som man finder på stranden, stammer fra koncentrering af tungsandet i de nedbrudte kystaflejringer. Iagttagelser tyder imidlertid på, at tungsandskoncentrater i større mængde ikke altid dannes på selve nedbrydningsstedet, og i det mindste ikke på steder, hvor der går en strøm langs kysten som ved Vesterhavet. Under sådanne forhold ser det ud til, at det tunge sand fra nedbrydningsområdet føres langs kysten og aflejres længere fremme, hvor bølger og strøm betinger en opbygning af kysten.

Særlig tydeligt træder dette forhold frem på stranden nord for Uggerby klitplantage. Man har her i den vestlige del, og det vil i hovedsagen sige vest for vejen, der fra Tolstrup fører ud på stranden, en udpræget nedbrydningskyst (april 1959), med en ret lav klint af marint sand. Der findes i klinten små væltede bjærgfyr, enebuske, udskredne lyngbuske og rødder. Havstokken går helt op til klintfoden, og der findes ikke i havstokken nogle helt lǿsrevne rester af vegetationen fra den nedbrudte kyst og heller intet drivgods. Graver man profiler i sandet på den høje strand og mellemstranden, finder man kun antydninger af tungsand som spredte, tynde mørke striber i profilet. Når man 
kommer et par hundrede meter $\phi$ st for den $\mathbf{f} \phi \mathbf{r}$ omtalte vej, er der ikke mere nogen nedbrydning. Der findes her bag sandstranden en meget bred, tilgroet, flad slette. På overgangen mellem sandstrand og det tilgroede findes et bælte fuldt af stærkt forrevne trærødder, rester af småtræer, lyngbuske, rødder af klitgræs, drivgods o. s. v., og i kanten af denne »lådne« strand og ind imellem de sammenskyllede træ- og buskrester findes ret betydelige mængder af tungsand i gode koncentrater på en strækning af over $1 \mathrm{~km}$. Den naturlige forklaring på disse forhold må være, at kyststrømmen og den overvejende vestlige vindretning fører materialet langs stranden fra vest mod $\emptyset$ st og aflejrer såvel planteresterne som det tunge sand på en kyststrækning længere fremme, hvor strømmen af en eller anden grund ikke fører til nedbrydning, men til opbygning.

Lignende forhold har man på stranden på strækningen fra L $\emptyset$ nstrup Klint og til Liver Å, hvor det er særlig tydeligt omkring Skallerup Klit. Kører man her ad vejen fra Sønderlev ud på stranden nedenfor Vesterhavsgaarden, da kører man ud i det efter min mening bedste tungsandsområde, der er iagttaget. Det er særlig lige neden for nedkørslen og 2-3 km i nord, at kysten er meget rig på tungsand, og her sker tilsyneladende også en opbygning på den høje strand. Alt efter årstiden kan stranden have et meget varierende udseende, men man finder næsten altid her store områder, hvor overfladen er meget sort og med betydelige mængder af drivgods og r $\varnothing$ dder fra klitvegetationen på den høje strand sammen med tungsandet. Går man syd på fra nedkørslen, da kommer man til et tydeligt nedbrydningsområde. Man har her en ret lav klint, der overvejende består af sand, og man ser tydeligt, hvordan klinten undermineres af bølgeslaget, således at de $\phi$ vre sandlag, der er gennemvævede af rødder, fra klitvegetationen hænger ud som et tag, der tid efter anden skrider ned. Selve havstokken er her overvejende fri for eller fattig på drivgods og planterester. Under visse forhold finder man gode tungsandskoncentrater ved klitfoden, delvis dækket af nedskredet sand, men efter en meget voldsom storm, hvor havet når ind og æder af klitten, synes disse tungsandslag også at skylle med. På denne nedbrydningskyst kan man, særlig i den sydlige del, på mellemstranden finde en del lagdelt tungsand, der ikke er særlig rig på malmsand.

På grundlag af de gjorte iagttagelser må man slutte, at langt den overvejende del af tungsandet fra nedbrydningsområdet syd for vejen af strømmen f $\varnothing$ res nogle $\mathrm{km}$ nord på og aflejres nord for nedk $\emptyset$ rslen, hvor bølger og strømforhold tillader en afsætning af det udvaskede materiale.

Når man på strækningen nord for L $\phi$ nstrup klint og i nord til Liver $\AA$ finder de meget betydelige mængder af tungsand, ligger det nær at 
antage, at en del udsorteres af de meget betydelige mængder sand, der igennem tiden skrider ud fra klinten og udvaskes, idet man på denne kyst har en kyststrøm i nordlig retning.

Også på strækningen Kandestederne-Skiveren er der gjort lignende iagttagelser. Nord for nedkørslen ved Kandestederne optræder tungsandet meget sparsomt. Lige ved nedkørslen og sydpå findes betydelige mængder af tungsand. På de første par $\mathrm{km}$ af stranden syd for nedkørslen har man en overvejende tilgroet klint, og desuden er de $\phi$ vre

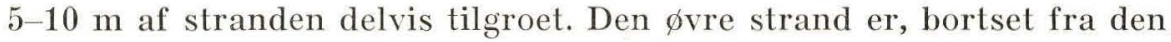
tørreste tid, delvis vanddækket i et bælte lige uden for den tilgroede фve strandbred, og dette vand er ferskvand, der siver til gennem klinten. Man har en meget bred strand, og der findes betydelige mængder af lagdelt tungsand, mest aflejret i det fugtige bælte og ind i den $\emptyset$ vre strandbred, der er under tilgroning. Tungsandet er relativt fattigt på malm, især i den nordlige del. Den her beskrevne tilstand er særlig karakteristisk for midterområdet af strækningen fra nedkørslen ved Kandestederne til Ny Studeli Rende, idet der dog i den sydlige del findes tungsand også på mellemstranden, og dette har et højere malmindhold. Området er rigt på drivgods.

Syd for Ny Studeli Mile skifter strandbredden karakter, idet der her på langs af stranden i godt $50 \mathrm{~m}$ afstand fra den gamle klint opbygges en ny lav klit. Overfladen af stranden var lys, men ved gravning fandt man, at der fra den ny klit og udefter fandtes et meget udbredt koncentreret tungsandslag, men dækket af 20-30 cm lyst sand. Tungsandslaget strakte sig flere steder $15-20 \mathrm{~m}$ ud fra den og med en mægtighed på op til $5 \mathrm{~cm}$ og mere. Den ny klit når i syd til den nordlige del af Råbjerg Stene, hvorpå den ebber ud. Ud for Råbjerg Stene fandtes på den høje strand et overfladelag af tungsand i en bredde på omkring $10 \mathrm{~m}$. Dette tungsand havde gennemgående et højere indhold af malm end de nordligere tungsandsforekomster på strækningen, idet især de $\emptyset$ verste $\mathrm{cm}$ var rige på sorte mineraler.

Syd herfor igen kom man til høje klinter med tydelige tegn på nedbrydning og uden tungsand af betydning på stranden. Også på denne strækning må udviklingen være den, at der fra nedbrydningskysten i syd mellem Skiveren og Råbjerg Stene sker en materialetransport langs kysten i nord $\phi$ stlig retning, og at der samtidig sker en sortering, der resulterer $i$, at det tunge sang aflejres på stranden længere fremme, hvor stranden ikke er udsat for en så kraftig påvirkning af strøm og bølger.

De her beskrevne 3 tungsandsområder, der så absolut er de rigeste, vi kender på Vestkysten i det nordlige Jylland, ligger efter de gjorte iagttagelser nogle $\mathrm{km}$ nord- $\phi$ st for nedbrydningskysten, aflejret på en strandbred, der er mindre udsat for strøm og bølger, hvilket fremgår 
af, at vegetationen vokser ud på strandbredden, og at der ofte i forbindelse med aflejringerne af tungsand findes betydelige mængder af drivgods og planterester, der for de sidstes vedkommende efter de gjorte iagttagelser må stamme fra nedbrydningskysten i syd-vest. Det tyder på, at tungsandet i disse aflejringer stammer fra nedbrudte kystområder.

I forbindelse med det foran anførte, der tyder på en transport i nordlig retning af nedbrydningsmaterialet fra klinterne ved Vesterhavet i Vendsyssel, skal også anf $\not$ res en iagttagelse, som jeg har gjort gentagne gange ved min færden på disse kyster. Tager man en spadefuld sand bestående af en blanding af tungsand og let sand og anbringer den i bølgeslagsområdet, da ser man, hvorledes der finder en sortering sted, når dette sand overskylles af bølgerne. Når bølgen skyller indad, tager den sand med sig fremad, og når den går tilbage, ser man, hvorledes den fjerner det lette lyse sand, således at det udkastede sand får en mørkere overflade. Efter at nogle få b $\phi$ lger har overskyllet en sådan sandblanding, har man en mørk, udtværet plet af mørkt tungsand; det lyse sand er forsvundet ud i havet. Men man ser også, at bølgeslagets kraft ikke virker vinkelret på kysten, idet de enkelte sandskorn, når bølgerne går indad, samtidig bevæges i nordlig retning.

Iagttagelser foretaget på kysten ved Liseleje tyder på, at tungsandet her i hovedsagen aflejres på stranden nedenfor nedbrydningsstedet. Efter en storm var der tydelige tegn på frisk nedbrydning af den marine, de fleste steder ret lave klint $\phi$ st for Liseleje, og der var gode koncentrater af tungsand på stranden nedenfor. Det nedbrudte marine materiale bestod af lagdelt sand med tynde lag af mørke mineraler. Længere фst på var der ingen tegn på nedbrydning af klinten, men her fandtes også kun ringe mængder af tungsand på strandbredden.

Der er i det foregående i hovedsagen kun omtalt de processer, der fører til koncentration af tungsand på kysten. Under forskellige forhold vil såvel havets som vindens kræfter føre til nedbrydning og spredning af de dannede koncentrater. Andetsteds omtales, hvorledes en betydelig mængde tungsand af vinden spredes på stranden eller føres ind i klitterne bag kysten. Men også bølgeslaget f $\emptyset$ rer under visse forhold til nedbrydning og spredning af de gode tungsandslag. Dette synes særlig at være tilfældet, når bølgerne når et stykke op på stranden uden at nå klintfoden. Under sådanne forhold kan de gode tungsandskoncentrater nedbrydes, og tungsandet kan spredes på mellemstranden. Under gunstige forhold vil der igen foregå en koncentrering af tungsandet.

Tilbage har man også spørgsmålet, om der vaskes tungmineral ud i havet under visse forhold. Da vi ikke har iagttagelser, der kan sige noget herom, må dette spørgsmål indtil videre stå åbent. 


\section{Vindens virkning.}

Som følge af vindens virkning danner der sig under visse forhold småklitter ind under klinten. Disse ansamlinger kan dels stamme fra vindtransporteret sand fra strandbredden, dels fra udblæst sand fra klinten, når denne består af flyvesand, hvad meget ofte er tilfældet. Sådanne ansamlinger af flyvesand er ofte rige på tungsand, og dette kan skyldes, at sandet på stranden er rigt på tungsand, men der vil sikkert også foregå en koncentration af tungsand her på grund af, at det lettere kvartssand har bedre betingelser for ved vindens hjælp at transporteres op over klinten. Man ser da også, at flyvesandet ved klintfoden og på stranden i det hele taget er mere rigt på tungsand end det nyaflejrede flyvesand inde bag klinten. Det er, som om vinden er i stand til at løfte kvartssandet, medens tungsandet mere transporteres ved rulning. Det er da også meget almindeligt, at det sorte tungsand har en vis tilbøjelighed til at samle sig ved klintfoden, det ser ud, som om det på grund af den højere vægt ruller ned ad den skrå klitflade. Sådanne klitter med meget tungsand på den høje strand er et meget fint udgangsmateriale for gode tungsandskoncentrater, når bølgerne ved stormflod kommer op og udvasker disse.

På Kattegatskysten syd for Skagen g $\phi r$ der sig iøvrigt særlige forhold gældende, idet der af vinden f $\phi$ res betydelige mængder flyvesand ud i Kattegat, ikke alene fra Sandmilen, men også fra fremkomne vindbrud i de mange klitter, der for en stor del dækker Vendsyssel nord for en linie Råbjerg-Hulsig. Læsiden af de åbne klitter og vindbrud viser næsten altid mørke skygger på grund af et overfladelag af tungsand. Når sandet med de overvejende vestlige vinde føres fra land og ud i Kattegat, da er der gode betingelser for en frasortering af tungsandet på kysten.

Selv om man ikke ud fra de hidtil foretagne noget spredte og tilfældige unders $\emptyset$ gelser kan give en udtǿmmende forklaring på dannelsen af de gode tungsandskoncentrater, så er der dog enkelte iagttagelser, der kan være grund til at fremhæe. De store tungsandsforekomster synes at være knyttet til kyster med gamle, marine sandaflejringer. Det må også anses for sandsynligt, at der i sådanne aflejringer, der tidligere har været kystaflejringer, er foregået en forkoncentration af tungsand.

Andeledes stiller det sig, hvor de marine (og andre) aflejringer er rige på sten og ral, idet der her ved nedbrydningen fremkommer kraftige strandvolde af sten og grus. Sådanne aflejringer er meget almindelige på store strækninger af Vesterhavskysten. På sådanne kyststrækninger er der meget dårlige betingelser for afsætning af tungsand. Undertiden ser man, at strandvolde af grus har et ret betydeligt ind- 
hold af tungsand, der udfylder hulrummene mellem stenene, men under sådanne forhold er der ingen produktionsmuligheder. Ganske vist finder man lokalt overfladiske sandaflejringer på sådanne strandvolde af grus og ral, men disse er da i reglen af ringe mægtighed og hviler på grus, hvorfra det ikke lader sig adskille. Sådanne forhold er bl.a. konstateret på stranden ved Bøvling Klit og ved Harboøre.

På kysten ud for Harboøre er der opkastet kolossale strandvolde af sten og grus, og på en lang strækning ligger der et par flere meter høje parallelle volde med en lavning imellem. Nogle steder består overfladen i lavningen af sand, og i forbindelse med dette kan der en del steder findes ret gode koncentrater af tungsand. Dette tungsand afviger imidlertid betydeligt fra tungsandet på de tilstødende sandstrande. Det er langt mere groft og mere rødt på grund af stort granatindhold. Den tanke ligger efter min mening nær, at dette grove tungsand delvis er af ny oprindelse, dannet ved afslidning af stenene i de omliggende strandvolde, der kastes rundt og slides mod hinanden af de kraftige bølger. Dette grove tungsand i tilknytning til strandvolde lader sig vanskeligere sortere i rene mineraler, idet mange af de store sandskorn ikke består af et enkelt mineral, men af flere sammenvoksede mineraler. 


\section{TUNGSANDETS MINERALINDHOLD}

Undersøgelserne af tungsandets mineralindhold er udf $\phi$ rt dels for at klarlægge, hvorvidt der forekommer mineraler, som kan være af $\phi$ konomisk betydning, dels for at belyse almene træk vedrørende tungsandets petrografi og geologi.

\section{Unders $\varnothing$ gelsesmaterialet.}

Unders $\emptyset$ gelserne er udf $\varnothing \mathbf{r t}$ på de ved terrænobservationerne indsamlede prøver. På nuværende tidspunkt er ca. 50 prøver analyseret. Ca. halvdelen af disse stammer fra de store tungsandsforekomster (se p. 13), medens de $\phi$ vrige er udtaget i små forekomster, som indtil videre ikke kan tillægges $\varnothing$ konomisk betydning.

Materialet er ikke indsamlet systematisk. Der foreligger således ikke gennemsnitspr $\varnothing$ ver fra de enkelte forekomster. Repræsentativiteten af materialet og dermed af analyseresultaterne kendes derfor ikke. I nogle tilfælde, hvor der foreligger flere pr $\phi$ ver fra samme forekomst, kan analyserne imidlertid give et indtryk af mineralindholdets variationer inden for samme forekomst.

\section{Undersøgelsesmetoder.}

Ved unders $\emptyset$ gelsernes tilrettelæggelse blev det under hensyntagen til opgavens formål og det forhåndenværende apparatur fundet hensigtsmæssigt at kombinere kemisk og petrografisk metodik. Med polarisationsmikroskop var det muligt at bestemme de gennemskinnelige (non-opake) mineraler. De uigennemskinnelige (opake) mineraler kunne imidlertid ikke bestemmes med tilfredsstillende sikkerhed på denne måde. Da disse mineraler måtte antages væsentligst at bestå af magnetit og ilmenit, skønnedes, at sammensætningen af disse mineraler med god tilnærmelse kunne bestemmes på basis af kvantitativ kemisk analyse af $\mathrm{Fe}$ - og Ti-indholdet.

Fremgangsmåden ved unders $\varnothing$ gelsen har været $\mathbf{f} \phi$ lgende: 
En repræsentativ del af hver prøve adskiltes i en let og en tung fraktion ved hjælp af bromoform (Vf. 2,9). Fraktionerne blev vejet, og procentmængden af let og tungt materiale beregnedes. De videre unders $\varnothing$ gelser har udelukkende omfattet den tunge fraktion.

Petrografisk an aly se.

Materialet til petrografisk analyse indlejredes i canadabalsam på objektglas. Disse præparaters mineralindhold unders $\varnothing$ gtes ved hjælp af polarisationsmikroskop. Unders $\varnothing$ gelsen udf $\varnothing$ rtes kvantitativt ved optælling af korn. Herved bestemtes følgende:

1. Procentmængden af opake (uigennemskinnelige) mineraler i den tunge fraktion ved optælling af 100 tungmineraler.

2. Den procentiske sammensætning af den non-opake (gennemskinnelige) tungmineralfraktion ved optælling af 100 non-opake tungmineraler.

Disse undersøgelser er i enkelte tilfælde suppleret med malmmikroskopiske observationer udført af dr. phil. H. PAuly.

$\mathrm{K}$ e $\mathrm{m}$ i s k an a l y s e.

Materialet til kemisk analyse blev pulveriseret og derefter smeltet med kaliumpyrosulfat. Smelten opløstes i ca. $10 \%$ (vol.) $\mathrm{H}_{2} \mathrm{SO}_{4}$. I den svovlsure opl $\varnothing$ sning reduceredes $\mathrm{Fe}+3$ og $\mathrm{Ti}+4$ til $\mathrm{Fe}^{+2}$ og $\mathrm{Ti}+3$ ved, at opløsningen ledtes gennem en Jones reduktor med $\mathrm{Zn}$-amalgam. Vædsken opfangedes $\mathrm{i}$ en kolbe under $\mathrm{CO}_{2}$-atmosfære, hvorefter $\mathrm{Fe}+$ Ti-indholdet bestemtes ved titrering med $\mathrm{KMnO}_{4}$. Ti-indholdet bestemtes dernæst ved titrering af en på lignende måde reduceret opløsning med ferriammoniumsulfat med kaliumrhodanid som indikator. Endelig bestemtes Fe-indholdet ved subtraktion.

På grund af vanskeligheder med at fremskaffe egnet zink til reduktoren er analysemetoden senere (efter prøve 72, se side 52) ændret således, at jernet bestemtes direkte ved reduktion med stannoklorid i saltsur opl $\varnothing$ sning, idet unders $\emptyset$ gelser har vist, at titanindholdet var uden indflydelse på jernbestemmelsen. Titan bestemtes efter reduktion med $\mathrm{Zn}$ i $\mathrm{CO}_{2}$-atmosfære og under opvarmning. Derefter titreredes titan med ferriammoniumsulfat og med kaliumrhodanid som indikator. - Denne metode er betydelig enklere og hurtigere og kræver kun zink af kvalitet, som nemt kan fremskaffes. Desuden er direkte analyser altid at foretrække for differensanalyser.

Ud fra det fundne indhold af $\mathrm{Ti}$ og $\mathrm{Fe}$ beregnedes indholdet af $\mathrm{FeTiO}_{3}$ og $\mathrm{Fe}_{3} \mathrm{O}_{4}$ i procent af den tunge fraktion, idet man forud- 
satte, at det fundne Ti-indhold var til stede som $\mathrm{FeTiO}_{3}$, og at et eventuelt overskud af $\mathrm{Fe}$ var til stede som $\mathrm{Fe}_{3} \mathrm{O}_{4}$.

\section{Mineralerne.}

De observerede mineraler og mineralgrupper omtales i det f $\phi$ lgende. Af hensyn til vurderingen af mineralernes $\phi$ konomiske muligheder er den kemiske formel anført for hvert mineral (efter A. N. og H. WinCHELL, 1951).

Opake mineraler er ikke specificeret ved petrograferingen. If $\varnothing l g e$ de kemiske unders $\varnothing$ gelser er gruppen repræsenteret ved magnetit $\left(\mathrm{Fe}_{3} \mathrm{O}_{4}\right)$ og ilmenit $\left(\mathrm{FeTiO}_{3}\right)$. Malmmikroskopiske undersøgelser har givet følgende resultat: Magnetit er et rent mineral. Det kan dog undertiden indeholde få \% ilmenit $\mathrm{i}$ form af lameller, samt spor af $\mathrm{Fe}_{2} \mathrm{O}_{3}$-mineraler, repræsenterende martitisering af magnetiten. Ilmenit er derimod sjældent ren, idet den indeholder lameller af hæmatit $\left(\mathrm{Fe}_{2} \mathrm{O}_{3}\right)$ i betydelig mængde. Ilmenitkornenes hæmatitindhold varierer fra ca. 0 til ca. $100 \%$ med en gennemsnitsværdi på skønsmæssigt $50 \%$. Disse mineralstrukturer er illustreret i fig. 1 .

Zirkon $\left(\mathrm{ZrSiO}_{4}\right.$; kan indeholde $\mathrm{Fe}_{2} \mathrm{O}_{3}, \mathrm{ThO}_{2}, \mathrm{Y}_{2} \mathrm{O}_{3}, \mathrm{HfO}_{2}, \mathrm{U}_{2} \mathrm{O}_{3}, \mathrm{H}_{2} \mathrm{O}$ etc). Kornene er undertiden idiomorfe, men ofte delvis begrænsede af brudflader; helt afrundede korn forekommer, men ikke i større mængder. Farven varierende: svagt rødligbrun, grålig, farveløs, undertiden med svagt grønlig eller gullig tone. Hovedparten er klare og fuldstændig gennemskinnelige, medens kun en mindre del er grumsede af minutiøse indeslutninger. Et betydeligt antal krystaller har veludviklet zonar struktur. Undertiden ses kraftige revnesystemer i kornene, hvilket tyder på, at radioaktive grundstoffer (U og/eller Th) forekommer i mineralet. Ved den radioaktive stråling nedbrydes $\mathrm{ZrSiO}_{4}$ nemlig til $\mathrm{ZrO}_{2}$ og $\mathrm{SiO}_{2}$ under rumfangsforøgelse. Spændingen forårsaget af rumfangsfor $\varnothing$ gelsen kan udløses gennem revnedannelser. Fig. 2 viser sådanne revner udgående fra et isotopt centralparti i mineralet. If $\varnothing$ lge kornenes magnetiske egenskaber (se p. 56) må en del af zirkonen antages at indeholde $\mathrm{Fe}_{2} \mathrm{O}_{3}$, medens en del, øjesynlig hovedparten, ikke er jernholdig.
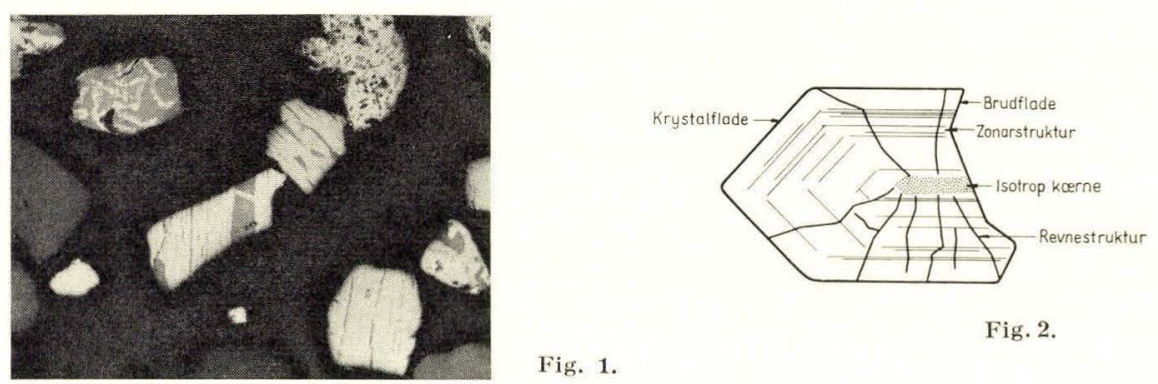

Fig. 2.

Fig. 1.

Fig. 1. Sammenvoksningsstrukturer i opake malmkorn bestående af magnetit, ilmenit (grả) samt hæmatit (hvid). Malmmikroskopisk optagelse udlånt af firmaet A. Laursen. Forstørrelse $70 \times$. Fig. 2. Strukturer i zirkonkorn; principskitse. 
Rutil $\left(\mathrm{TiO}_{2}\right.$; kan indeholde indtil $36 \% \mathrm{Ta}_{2} \mathrm{O}_{5}, 32 \% \mathrm{Nb}_{2} \mathrm{O}_{5}, 16 \% \mathrm{FeO}$; også mindre mængder af $\mathrm{Fe}_{2} \mathrm{O}_{3}, \mathrm{MnO}, \mathrm{SnO}_{2}$ kan forekomme). Idiomorfe til afrundede korn. Farven varierende: ræver $\varnothing$, brun, gråligbrun med gylden tone. Oftest tydelig pleocroisme.

Titanit $\left(\mathrm{CaTiOSiO}_{4}\right.$; kan indeholde $\mathrm{Fe}+++, \mathrm{Al}, \mathrm{Y}, \mathrm{Ce}, \mathrm{Cb}, \mathrm{Na}$; visse varieteter kan indeholde indtil $\left.12 \%(\mathrm{Y}, \mathrm{Ce}){ }_{2} \mathrm{O}_{3}\right)$. Overvejende afrundede korn; farveløs til grålig. Undertiden spores svag pleocroisme.

Monazit $\left(\mathrm{CePO}_{4}\right.$; Ce ofte erstattet af La, Nd, Pr, Er, etc.; Th og Si ofte til stede). Enkelte korn er henført til monazit på basis af følgende egenskaber: aflang ægformig, kantslidt korn; høj lysbrydning og dobbeltbrydning (ca som zirkon); svag gullig farve; skæv udslukning

Turmalin ( $(\mathrm{Na}, \mathrm{Ca})_{5}(\mathrm{Al}, \mathrm{Fe}, \mathrm{Mg}, \mathrm{Mn}, \mathrm{Ti})_{27}(\mathrm{Si}, \mathrm{B})_{27} \mathrm{O}_{86}(\mathrm{OH})_{4}$ (?); visse varieteter indeholder Ce og $\mathrm{Cr}$ ). Oftest kantslidte brudstykker; enkelte idiomorfe krystaller. Farven overvejende brun, sjældnere grønliggrå, kraftig pleocroisme.

Staurolit ( $\mathrm{HFe}_{2} \mathrm{Al}_{9} \mathrm{O}_{8} \mathrm{Si}_{4} \mathrm{O}_{16} ; \mathrm{Fe}$ kan erstattes af $\mathrm{Mg}, \mathrm{Mn}$, Co, Ni). Oftest uregelmæssige brudstykker med varierende afrundingsgrad.

Cyanit $\left(\mathrm{Al}_{2} \mathrm{OSiO}_{4}\right.$; lidt $\mathrm{Na}_{2} \mathrm{O}, \mathrm{K}_{2} \mathrm{O}$ og $\mathrm{H}_{2} \mathrm{O}$ ofte til stede; desuden $\mathrm{Fe}+++$ og Ca). Spaltestykker, ofte kantrundede.

Sillimanit $\left(\mathrm{Al}_{2} \mathrm{OSiO}_{4}\right)$. Spaltestykker; tværenderne undertiden svagt tandede.

Granat-gruppen. (Generel formel; $\mathrm{A}_{3} \mathrm{~B}_{2}\left(\mathrm{SiO}_{4}\right)_{3} ; \mathrm{A}$ kan være $\mathrm{Ca}, \mathrm{Fe}+2$, $\mathrm{Mn}+2 ; \mathrm{B}$ kan være $\mathrm{Al}, \mathrm{Cr}, \mathrm{Fe}+3 ; \mathrm{SiO}_{4}$ kan partielt erstattes med $\mathrm{PO}_{4}$ ). Overvejende brudstykker, oftest noget afrundede, enkelte med spor af oprindelig krystalbegrænsning. Ætsningsmærker (bl. a. terningformige) ses undertiden. Farven varierende: farvel $\varnothing$, lys r $\varnothing \mathrm{dviolet,} \mathrm{mørk} \mathrm{r} \phi \mathrm{d}$, brunr $\varnothing \mathrm{d}$; sjældent gr $\varnothing$ nlig.

Epidot-gruppen omfatter pistacit $\left(\mathrm{Ca}_{2}(\mathrm{Al}, \mathrm{Fe})_{2} \mathrm{OHSi}_{3} \mathrm{AlO}_{12}\right)$, clinozoisit og zoisit $\left(\mathrm{Ca}_{2} \mathrm{Al}_{2} \mathrm{OHSi} \mathrm{AlO}_{32}\right)$. Spaltestykker, til dels med uregelmæssig begrænsning, undertiden afrundede. Kornene overvejende klare og gennemsigtige, sjældnere grumsede af indeslutninger og omdannelsesprodukter. Pistacit er gruppernes dominerende mineral.

Amfibol-gruppen omfatter hornblende $\left(\mathrm{Ca}_{2}(\mathrm{Mg}, \mathrm{Fe})_{3} \mathrm{Al}_{2}(\mathrm{OH})_{2} \mathrm{Si}_{6} \mathrm{Al}_{2} \mathrm{O}_{22}\right.$; eller $\mathrm{NaCa}_{2}(\mathrm{Mg}, \mathrm{Fe})_{5}(\mathrm{OH})_{2} \mathrm{Si}_{7} \mathrm{AlO}_{22}$; eller $\left.\mathrm{NaCa}_{2}(\mathrm{Mg}, \mathrm{Fe})_{4} \mathrm{Al}(\mathrm{OH})_{2} \mathrm{Si}_{6} \mathrm{Al}_{2} \mathrm{O}_{22}\right)$, aktinolit $\left(\mathrm{Ca}_{2}(\mathrm{Mg}, \mathrm{Fe})_{5}(\mathrm{OH})_{2} \mathrm{Si}_{8} \mathrm{O}_{22}\right)$ og tremolit $\left(\mathrm{Ca}_{2} \mathrm{Mg}_{5}(\mathrm{OH})_{2} \mathrm{Si}_{8} \mathrm{O}_{22}\right)$. Spaltestykker, undertiden med tandede tværender. Større korn sædvanligvis kantslidte. Hornblende, der er gruppens dominerende mineral, er væsentligt repræsenteret ved den blågrønne type.

Pyroxen-gruppen omfatter augit $\left(\mathrm{Ca}(\mathrm{Mg}, \mathrm{Fe}) \mathrm{Si}_{2} \mathrm{O}_{6}\right.$; med $\mathrm{Mg}_{2} \mathrm{Si}_{2} \mathrm{O}_{6}$ og $\mathrm{Al}_{2}$ $\mathrm{Al}_{2} \mathrm{O}_{6}$ ), diopsid ( $\left.\mathrm{CaMgSi}_{2} \mathrm{O}_{6}\right)$ og hypersten ( $\left.(\mathrm{Mg}, \mathrm{Fe}) \mathrm{SiO}_{3}\right)$. Spaltestykker, undertiden kantrunding. 
Alterit-gruppen omfatter forskellige grumsede, aggregatpolariserede korn af ubekendt sammensætning.

\section{Mineralfordelingen.}

Resultaterne af de kvantitative kemiske og petrografiske analyser er anf $\varnothing$ rt i tabellen p. 36 og gengivet grafisk i tavle I. Heraf ses, at der kan være betydelige variationer i mineralfordelingen fra pr $\phi$ ve til pr $\phi v e$. Systemet i disse variationer skal søges belyst i det f $\varnothing$ lgende.

Sammenligning mellem petrografiskogkemisk a n a 1 y se.

Det kunne ventes, at indholdet af opake mineraler fundet ved petrograferingen ville svare ret nøje til indholdet af $\mathrm{Fe}_{3} \mathrm{O}_{4}+\mathrm{Fe}^{\prime} \mathrm{TiO}_{3}$ (»malm《) fundet ved kemisk analyse. Af tabel I ses imidlertid, at dette ikke altid er tilfældet. Årsagen hertil skal søges belyst i det følgende.

En faktor, der må tillægges betydning, er den statistiske usikkerhed på analyseresultaterne. Til nærmere bed $\varnothing$ mmelse heraf er der i fig. 3 vist en sammenstilling af de petrografiske og kemiske analyser med angivelse af $95 \%$-konfidensintervaller (se E. Poulsen, 1958; G. LARSEN, 1959, p. 82) for de ved petrograferingen fundne mineralhyppigheder. Et $95 \%$-konfidensinterval er et interval, som med en sandsynlighed på $95 \%$ omslutter hyppighedens middelværdi. Af fig. 3 ses følgende.

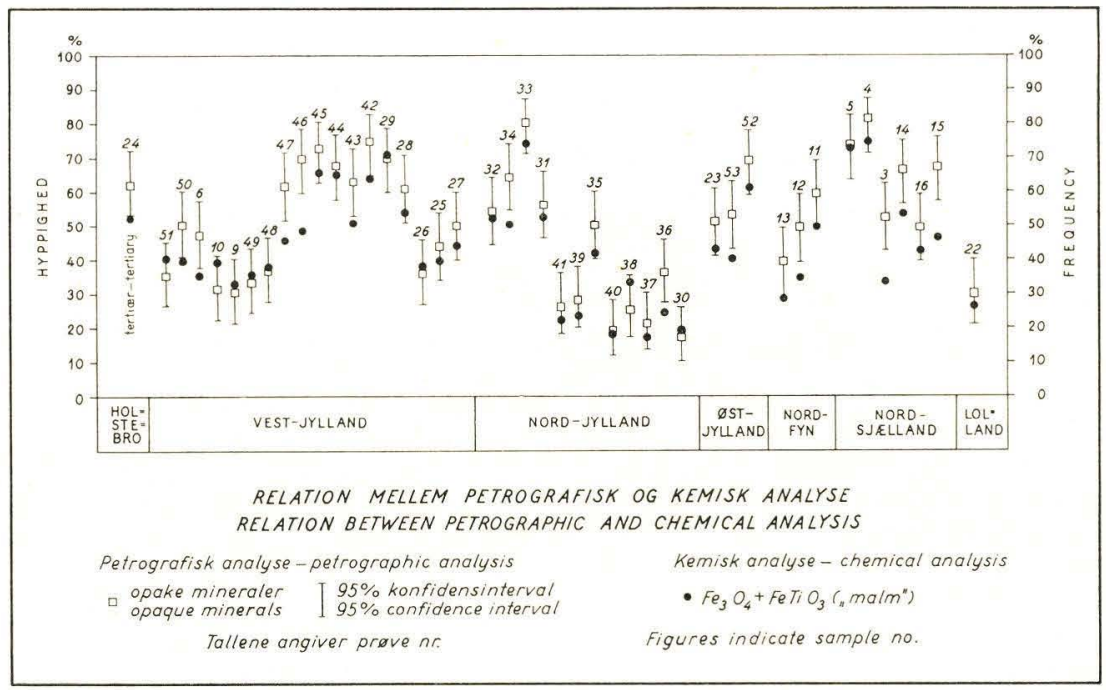

Fig. 3. 
MiNerALFordelingen I TUNGSANDET.

\begin{tabular}{|c|c|c|c|c|c|c|c|c|c|c|c|c|c|c|c|c|c|c|c|c|c|}
\hline \multirow[b]{3}{*}{$\begin{array}{l}\dot{\Xi} \\
\vdots \\
\vdots \\
\vdots \\
\vdots\end{array}$} & \multirow{3}{*}{ Lokalitet } & \multirow{3}{*}{ 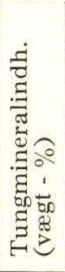 } & \multicolumn{5}{|c|}{$\begin{array}{c}\text { Vægt \% af tung fraktion } \\
\text { Kemisk analyse }\end{array}$} & \multicolumn{14}{|c|}{ Petrografisk analyse (antal - \%) } \\
\hline & & & \multirow[b]{2}{*}{$\ddot{H}$} & \multirow[b]{2}{*}{ 记 } & \multicolumn{3}{|c|}{$\begin{array}{l}\mathrm{Ti} \text { og } \mathrm{Fe} \\
\text { beregnet som: }\end{array}$} & \multirow{2}{*}{ 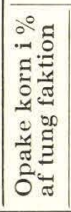 } & \multicolumn{13}{|c|}{$\begin{array}{l}\text { Procentisk fordeling af non-opake } \\
\text { mineraler }\end{array}$} \\
\hline & & & & & 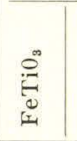 & 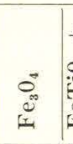 & 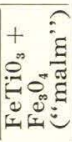 & & 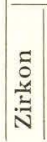 & $\underset{\Xi}{\Xi}$ & $\stackrel{\vec{\Xi}}{\stackrel{\vec{\Xi}}{*}}$ & 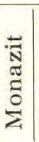 & 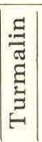 & 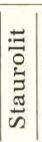 & 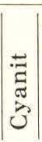 & 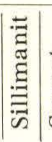 & 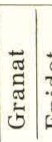 & $\begin{array}{l}\overrightarrow{0} \\
\stackrel{0}{\vec{a}} \\
\text { âl }\end{array}$ & & 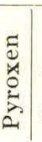 & \\
\hline 24 & Holstebro (tertiær) & 43 & 25.7 & 19.3 & 52.4 & - & 52.4 & 62 & 23 & 15 & 1 & - & 1 & + & 10 & & 49 & & 1 & - & - \\
\hline 20 & $\mathrm{~S}$ for Blåvan & 4,5 & & inger & $n$ anal & lyse & & 60 & 14 & + & 1 & - & 1 & 1 & 2 & - & & $33: 3$ & 36 & 3 & - \\
\hline 18 & $\mathrm{~N}$ for Blåvands Huk. & 3,7 & & inger & $\mathrm{n}$ anal & lyse & & 42 & 1 & 2 & - & - & - & 1 & $\overline{4}$ & 3 & & 254 & 49 & 5 & 6 \\
\hline 19 & $\mathrm{~N}$ for Blåvands Huk. . & 5.2 & & inger & $\mathrm{n}$ anal & lyse & & 54 & 9 & 2 & 1 & - & + & + & 4 & & & 224 & 44 & 1 & 2 \\
\hline 21 & Vejrs ........ & 6,7 & & inger & $\mathrm{n}$ ana & lyse & & 61 & 16 & 2 & 2 & - & - & - & 2 & 1 & & 253 & 36 & 5 & 2 \\
\hline 6 & Lyngvig. . & 72 & 11,6 & 13,2 & 35,8 & -1 & 35,8 & 48 & 7 & 5 & 1 & - & - & 2 & - & & & 13 & 4 & 2 & 1 \\
\hline 50 & Lyngvig. & 71 & 12,7 & 14,8 & 40,1 & - & 40,1 & 51 & 22 & 6 & $\hat{1}$ & - & 2 & 1 & - & & 431 & 131 & 11 & - & \\
\hline 51 & & 39 & 11,8 & 16,4 & 37,4 & 3,6 & 41,0 & 36 & 8 & 1 & - & - & 1 & - & 3 & & 491 & 141 & 16 & 4 & 4 \\
\hline 9 & Sø & 33 & 9,9 & 11 , & 31,4 & 0,3 & 31,7 & 31 & 5 & 1 & - & - & 1 & 2 & 4 & & 482 & 231 & 11 & 3 & 1 \\
\hline 10 & Søndervig . & 41 & 10,7 & 16,5 & 33,7 & 5,7 & 39,4 & 32 & 10 & 2 & - & - & 1 & 4 & 4 & & 591 & 12 & 5 & 2 & 1 \\
\hline 48 & $S$ for Sundhus & 66 & 11,7 & 14,3 & 37,2 & 0,9 & 38,1 & 37 & 2 & 2 & - & - & 1 & 3 & 3 & & 611 & 131 & 10 & 2 & 2 \\
\hline 49 & $S$ for Sundhus & 84 & 11,0 & 13,2 & 35,0 & 0,5 & 35,5 & 34 & 11 & 1 & - & - & - & 2 & 1 & & 70 & 9 & 2 & 2 & 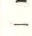 \\
\hline 47 & $\mathrm{~N}$ for Bjerghus & 90 & 11,4 & 20,7 & 36,0 & 10,3 & 46,3 & 62 & 31 & 1 & - & - & - & - & - & & 62 & 6 & - & - & - \\
\hline 46 & Bøv & 91 & 10,8 & 23,6 & 34,1 & 15,3 & 49,4 & 70 & 36 & 4 & + & - & - & 1 & 2 & & 52 & 2 & 1 & 1 & 1 \\
\hline 45 & & 97 & 11,3 & 34,6 & 35,9 & 29,6 & 65,5 & 73 & 41 & 4 & - & - & - & 1 & 1 & & 49 & - & 3 & - & 1 \\
\hline 44 & SV $\mathrm{f}$ & 91 & 7,4 & 38,5 & 23,6 & 41,2 & 64,8 & 68 & 30 & 4 & - & - & - & 1 & 1 & & 50 & 6 & 3 & 3 & 2 \\
\hline 29 & & 92 & 10,1 & 40,0 & 32,0 & 38,9 & 70,9 & 70 & 31 & 2 & - & - & - & 2 & 1 & & 55 & 4 & - & 3 & \\
\hline 42 & $\mathrm{Fja}$ & 97 & 11,4 & & 36,1 & 28,1 & 64,2 & 75 & 38 & 2 & - & - & - & - & 1 & & 43 & 7 & 6 & 3 & \\
\hline 43 & Fja & 92 & 9,6 & 26,5 & 30,3 & 21,2 & 57,5 & 63 & 18 & 1 & - & - & 1 & 2 & - & & 69 & 4 & 4 & 1 & - \\
\hline 28 & S. V & 84 & 10,9 & 27,0 & 34,5 & 19,7 & 54,2 & 61 & 13 & 6 & - & - & 1 & 2 & 1 & & 62 & 1 & 6 & 3 & 5 \\
\hline 25 & Har & 68 & 9,7 & 17,9 & 30,7 & 9,1 & 39,8 & 44 & 5 & 1 & + & 1 & 1 & 3 & 1 & & 601 & 14 & 9 & 3 & 2 \\
\hline 26 & Har & 63 & 9,3 & 15,9 & 29,4 & 7,1 & 36,5 & 36 & 8 & 2 & - & - & - & 1 & 2 & & 561 & 151 & 10 & 5 & 1 \\
\hline 27 & Tybs & 42 & 10,2 & 20,2 & 32,2 & 11,6 & 43,8 & 50 & 13 & 7 & - & - & - & 1 & 3 & & 58 & 6 & 8 & 2 & 1 \\
\hline 32 & & 88 & 8,9 & 27,8 & 28,3 & 24,0 & 52,3 & 54 & 15 & 1 & 3 & 1 & - & 2 & - & & 68 & 5 & 6 & - & - \\
\hline 31 & $\mathrm{Sk}$ & 82 & 9,7 & 25,8 & 30,7 & 21,5 & 52,2 & 56 & 15 & 6 & 2 & - & - & 2 & - & & 57 & 9 & 7 & 1 & 1 \\
\hline 33 & & 93 & 8,6 & 43,6 & 27,5 & 46,3 & 73,8 & 80 & 19 & 3 & 2 & - & 1 & + & 4 & & \begin{tabular}{l|l}
39 & 1
\end{tabular} & 151 & 12 & 1 & 3 \\
\hline 34 & & 80 & 9,1 & 26,0 & 28,9 & 21,3 & 50,2 & 64 & 17 & 3 & - & - & - & - & - & & 571 & 11 & 9 & 2 & 1 \\
\hline 35 & & 94 & 11,3 & 17,2 & 35,9 & 5,5 & 41,4 & 50 & 17 & 2 & 3 & - & - & 1 & - & & 65 & 8 & 1 & 2 & 1 \\
\hline 39 & & 78 & 7,5 & 8 & 22,9 & - & 23,3 & 28 & 18 & 1 & 2 & - & 1 & 1 & - & & 52 & & 13 & 2 & 2 \\
\hline 41 & Kal & 64 & 6,9 & 8,3 & 21,9 & 0,4 & 22,3 & 26 & 8 & 1 & 2 & - & 1 & - & - & & \begin{tabular}{l|l}
48 & 2
\end{tabular} & 211 & 15 & 3 & 1 \\
\hline 40 & Ska & 72 & 5,8 & 7,0 & 18,4 & 0,3 & 18,7 & 19 & 3 & 3 & 1 & - & - & 1 & 1 & & \begin{tabular}{l|l}
30 & 2 \\
-
\end{tabular} & 252 & 28 & 6 & 2 \\
\hline 30 & f. Klitgården & 25 & 5,1 & 7,9 & 16,2 & 2,7 & 18,9 & 17 & 7 & 2 & 1 & - & - & - & 2 & & 301 & 183 & 30 & 9 & - \\
\hline 37 & f. Klitgården. & 73 & 4,3 & 6,9 & 13,7 & 2,6 & 16,3 & 21 & 8 & 1 & 3 & - & - & 1 & - & & 511 & 151 & 17 & 3 & - \\
\hline 38 & Klitgården. & 95 & 6,6 & 16,7 & 20,9 & 12,4 & 33,3 & 25 & 13 & 2 & - & - & - & & 2 & & \begin{tabular}{l|l}
591 & 1
\end{tabular} & 12 & 5 & 5 & 2 \\
\hline 36 & & 77 & 6,1 & 10,6 & 19,5 & 4,7 & 24,2 & 36 & 9 & + & 2 & - & - & 1 & 1 & & \begin{tabular}{l|l}
51 & 1
\end{tabular} & 151 & 15 & 4 & 2 \\
\hline 23 & egtrup Vig. & 48 & 7,7 & 22,2 & 24,5 & 18,2 & 42,7 & 51 & 3 & 2 & - & - & 1 & 1 & 1 & & 47 & & 32 & 2 & 4 \\
\hline 53 & & 42 & 9,2 & 18,2 & 29,1 & 10,3 & 39,4 & 53 & 7 & 3 & - & - & - & 1 & 1 & & 60 & & 13 & 3 & 3 \\
\hline 52 & & 64 & 15,5 & 26 , & 49,1 & 11,8 & 60 , & 69 & 26 & 2 & - & - & - & - & 1 & & 55 & 6 & 6 & 2 & 2 \\
\hline 11 & $\mathrm{R}$ & 73 & 9,0 & 24,9 & 28,5 & 19,9 & 48,4 & 59 & 7 & 2 & - & - & - & 3 & 3 & & \begin{tabular}{l|l}
57 & 1
\end{tabular} & & 10 & 4 & - \\
\hline 13 & se.... & 40 & 6,4 & 13,1 & 20,3 & 7,8 & 28,1 & 39 & 4 & - & 1 & - & + & + & - & & 57 & & 25 & 2 & 1 \\
\hline 12 & & 73 & 8,1 & 15,6 & 25,8 & 8,4 & 34,2 & 49 & - & 3 & 1 & - & 1 & 2 & - & & 77 & 6 & 7 & 3 & - \\
\hline 3 & Liseleje . . . . & 40 & 5,4 & 17,7 & 17,2 & 15,7 & 32,9 & 52 & 7 & + & 2 & - & 1 & - & - & & 56 & & 20 & 6 & 1 \\
\hline 4 & Liseleje. & 96 & 9,5 & 42,6 & 30,0 & 43,5 & 73,5 & 81 & 12 & 6 & 1 & - & 2 & + & - & & \begin{tabular}{l|l}
63 & 1 \\
\end{tabular} & 10 & 4 & + & - \\
\hline 5 & & 96 & 9,0 & 41,9 & 28,6 & 43,4 & 72,0 & 73 & 8 & 3 & 1 & - & & 1 & - & & 72 & & 10 & 2 & - \\
\hline 14 & & 60 & 8,6 & 28,8 & 27,1 & 26,0 & 53,1 & 66 & 4 & 2 & 1 & - & 1 & 1 & - & & 661 & 111 & 12 & 2 & - \\
\hline 15 & & 55 & 6,9 & 25,5 & 21,8 & 24,2 & 46,0 & 67 & 6 & 2 & 2 & - & 1 & - & - & & 53 & & 29 & 2 & \\
\hline 16 & Råg & 45 & 6,7 & 22,8 & $21,2 \mid$ & 20,7 & 41,9 & 49 & 3 & - & 2 & - & - & - & - & & 55 & & 32 & 4 & - \\
\hline 17 & & 11 & & ingen & analy & yse & & 23 & 3 & 1 & - & - & - & - & - & & 181 & 145 & 59 & 3 & 2 \\
\hline 22 & Rødby Havn ... & 79 & 7,4 & 10,5 & 23,6 & 2,5 & 26,1 & 30 & 1 & 4 & - & - & 2 & 1 & - & & 81 & 5 & 5 & 1 & - \\
\hline B.A. & $\begin{array}{l}\text { Bornholm; stranden } \\
\text { ved Arnager }\end{array}$ & 90 & & ingen & analy & & & 78 & 67 & 3 & - & - & - & - & 1 & & 26 & - & 2 & - & 1 \\
\hline
\end{tabular}


1. Der er en generel tendens til, at de kemiske analyser ligger lavere end de petrografiske (ca $70 \%$ lavere; ca $20 \%$ næsten lig med: ca $10 \%$ højere).

2. Ca $2 / 3$ af de kemiske analyser falder inden for $95 \%$-konfidensintervallerne, medens ca $1 / 3$ falder udenfor.

De større afvigelser kan således ikke skyldes den statistiske usikkerhed, men må tilskrives andre årsager.

Ved senere kemiske analyser har det vist sig, at en del af malmmineralerne vanskeligt spaltedes ved en enkelt smeltning med kaliumpyrosulfat. Dette kan være en af grundene til at analysernes værdier for Fe og Ti ligger lidt for lavt. De senere analyser (tabellen p. 52) er fremkommet efter to smeltninger med kaliumpyrosulfat.

Forklaringen på de registrerede forskelle kan endvidere være den, at nogle af de opake mineraler har en anden sammensætning end forudsat ved den kemiske analyse, hvilket er vist ved hjælp af malmmikroskopisk unders $\emptyset$ gelse (se p. 33). Dette forhold har medf $\phi \mathbf{r t}$, at der senere er foretaget en række magnetiske fraktionsanalyser (se p. 51).

En anden faktor, som kan spille en rolle, er en eventuel uensartethed i materiale udtaget til henholdsvis kemisk og petrografisk unders $\varnothing$ gelse. Da materialet imidlertid blev blandet omhyggeligt f $\varnothing \mathrm{r}$ pr $\varnothing v e-$ udtagningen, kan denne usikkerhed næppe forklare de st $\phi$ rre afvigelser.

Det forhold, at de kemiske analyser angiver vægt-\%, medens de petrografiske analyser angiver antal- $\%$ af mineralhyppighed, kan forklare en del af de registrerede forskelle. Da det har vist sig, at de opake mineraler generelt set har mindre kornstørrelse end hovedparten af de $\phi$ vrige tungmineraler (se p. 39), kunne det forventes, at vægt- $\%$ angivelserne ville være mindre end antal-\%, hvilket netop ofte er tilfældet.

De forskelle, der er konstateret mellem de kemiske og petrografiske analyser, må således næppe tilskrives en enkelt årsag, men et sammenspil af flere faktorer.

Mineralfordelingens relation til kon centrationsgraden.

Af tabel 1 ses, at tungsandets mineralsammensætning viser iøjnefaldende relationer til koncentrationsgraden. Granat er således almindeligvis stærkt fremtrædende i prøver med stort tungmineralindhold, medens epidot og hornblende fremhersker i svagt koncentrerede prøver. Årsagen må sandsynligvis til dels søges i mineralernes forskellige vagtfylde. 


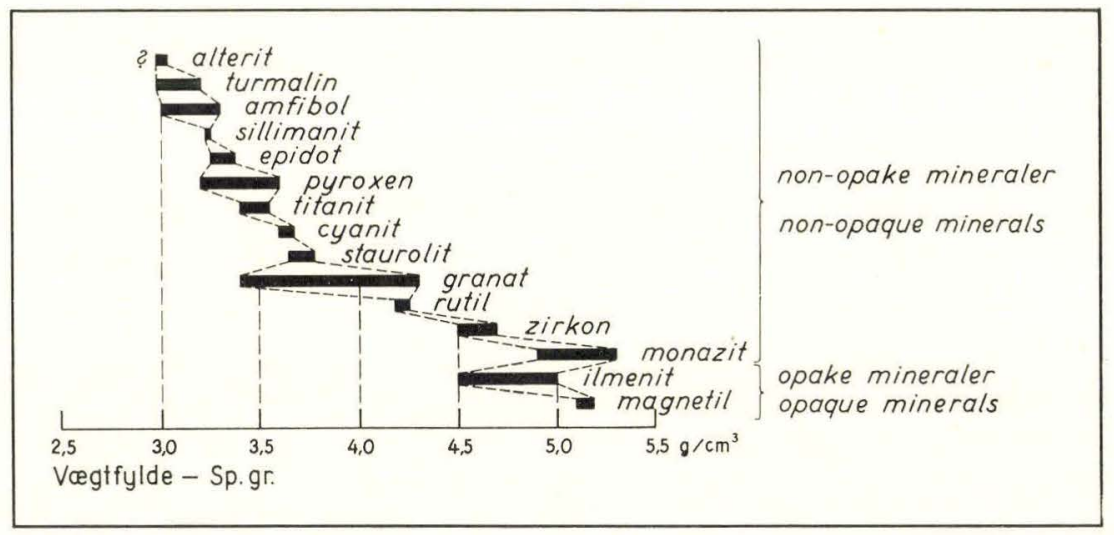

Fig. 4. Oversigt over tungmineralernes vægtfylde.

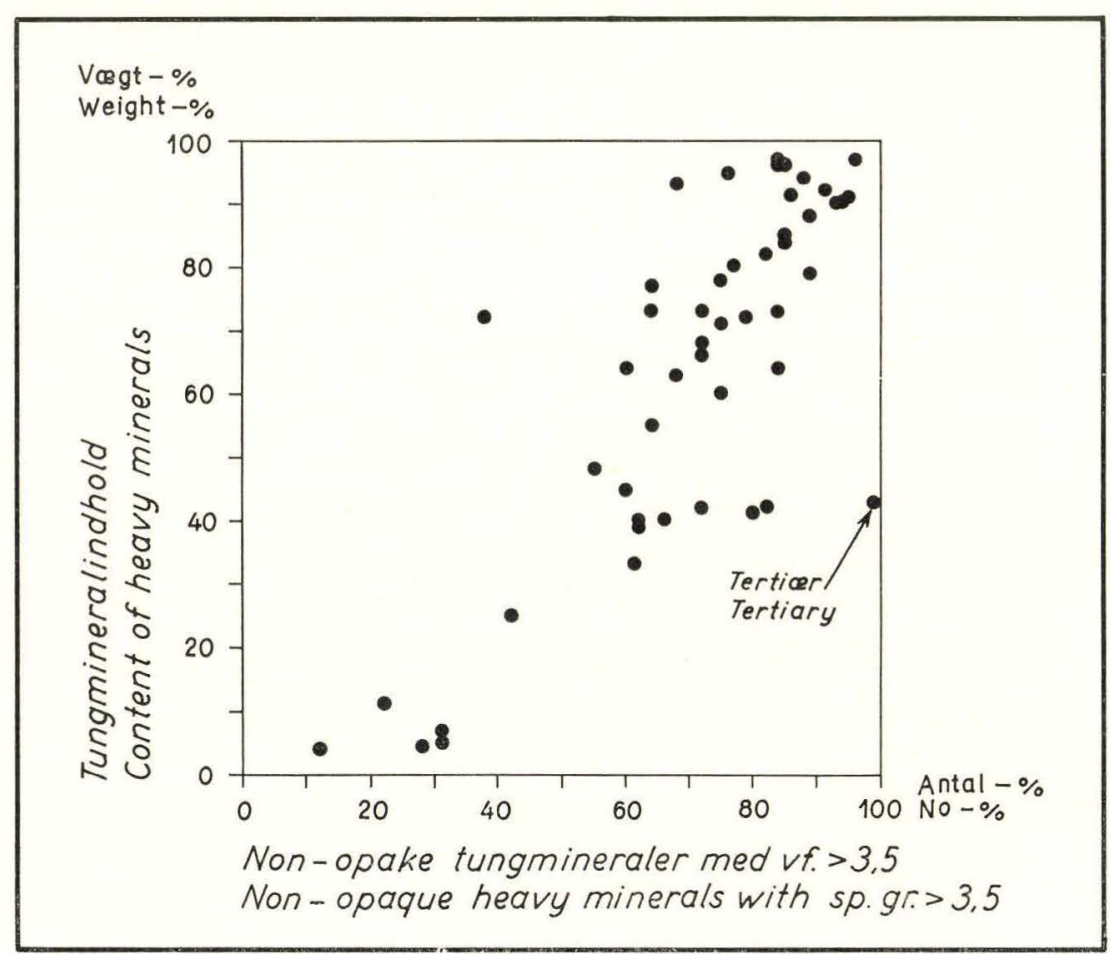

Fig. 5. Hyppigheden af de tungeste mineraler i relation til tungmineralkoncentrationen.

I fig. 4 er de registrerede tungmineralers vægtfylde indtegnet (efter H. B. Milner, 1952). I diagrammet fig. 5 er tungmineralprocenten sammenstillet med den non-opake tungmineralfraktions procentmængde af mineraler med st $\phi$ rre vægtfylde end 3,5 , d.v. s. mineralerne titanit-monazit i fig. 4. Diagrammet illustrerer, at mængden af 
de tungeste gennemskinnelige mineraler tiltager med stigning i tungmineralprocenten. Heraf udledes, at vægtfylden er en af de kornegenskaber, som er bestemmende for mineralfordelingen under tungsandsaflejringernes dannelse.

Mineralfordelingen s

relation tilkornst $\varnothing$ rrelsen.

For nærmere at belyse hvilke egenskaber ved mineralerne, der er bestemmende for tungsandets mineralfordeling, er der foretaget mineralogiske fraktionsanalyser. Fremgangsmåden har været følgende. 14 prøver af tungsand fra forskellige lokaliteter og af forskellig koncentrationsgrad er ved sigtning opdelt i kornstørrelsesfraktioner uden forudgående separation i bromoform. De enkelte fraktioner blev derefter unders $\emptyset$ gt mikroskopisk, hvorved den procentiske hyppighed af f $\phi$ lgende mineralgrupper bestemtes: 1) opake mineraler, 2) zirkon, 3) фvrige tungmineraler og 4) lette mineraler. Resultaterne er sammenstillet i fig. 6, hvor de enkelte analyseresultater samt gennemsnitsværdierne er indtegnet.

Af figuren ses, at der i kornfraktionerne større end $0.063 \mathrm{~mm}$ træffes en jævn ændring i mineralfordelingen med stigning i kornst $\varnothing$ rrelsen, idet

1. de tungeste mineraler, d. v. s. opake korn og zirkon, hvis vf. er ca. 4,5-5, dominerer i de finkornede fraktioner

2. de lette mineraler, der har en vægtfylde på ca. 2,7, dominerer i de grove fraktioner

3. de $\phi$ vrige tungmineraler, hvis vf. væsentligst ligger i området 3-4, fremhersker i de mellemste kornfraktioner.

Tilsvarende fordelingskurver for mineralerne er tidligere registreret i slesvig-holstenske »Erz-Granatseifen« (R. WEyL, 1937).

Fordelingen viser, at kornvægten (størrelse $X$ vægtfylde) tenderer imod at være ens fra fraktion til fraktion. Det kan derfor antages, at kornvægten, altså kombinationen kornstørrelse-vægtfylde, er en egenskab ved materialet af afg $\phi$ rende betydning for mineralfordelingen ved tungsandsaflejringernes dannelse. Denne opfattelse er i overensstemmelse med C. W. Conrens (1949, p. 222, fig. 366), der anfører at mineralerne i tunge sandlag er udsorteret efter vægt.

Kornfraktionen $<0.063 \mathrm{~mm}$ afviger fra de $\phi$ vrige fine fraktioner ved ofte at indeholde betydelige mængder af lette mineraler. Årsagen hertil er muligvis den, at de fineste partikler er aflejret i læ mellem de større korn og således repræsenterer andre aflejringsbetingelser end det $\varnothing$ vrige materiale. 


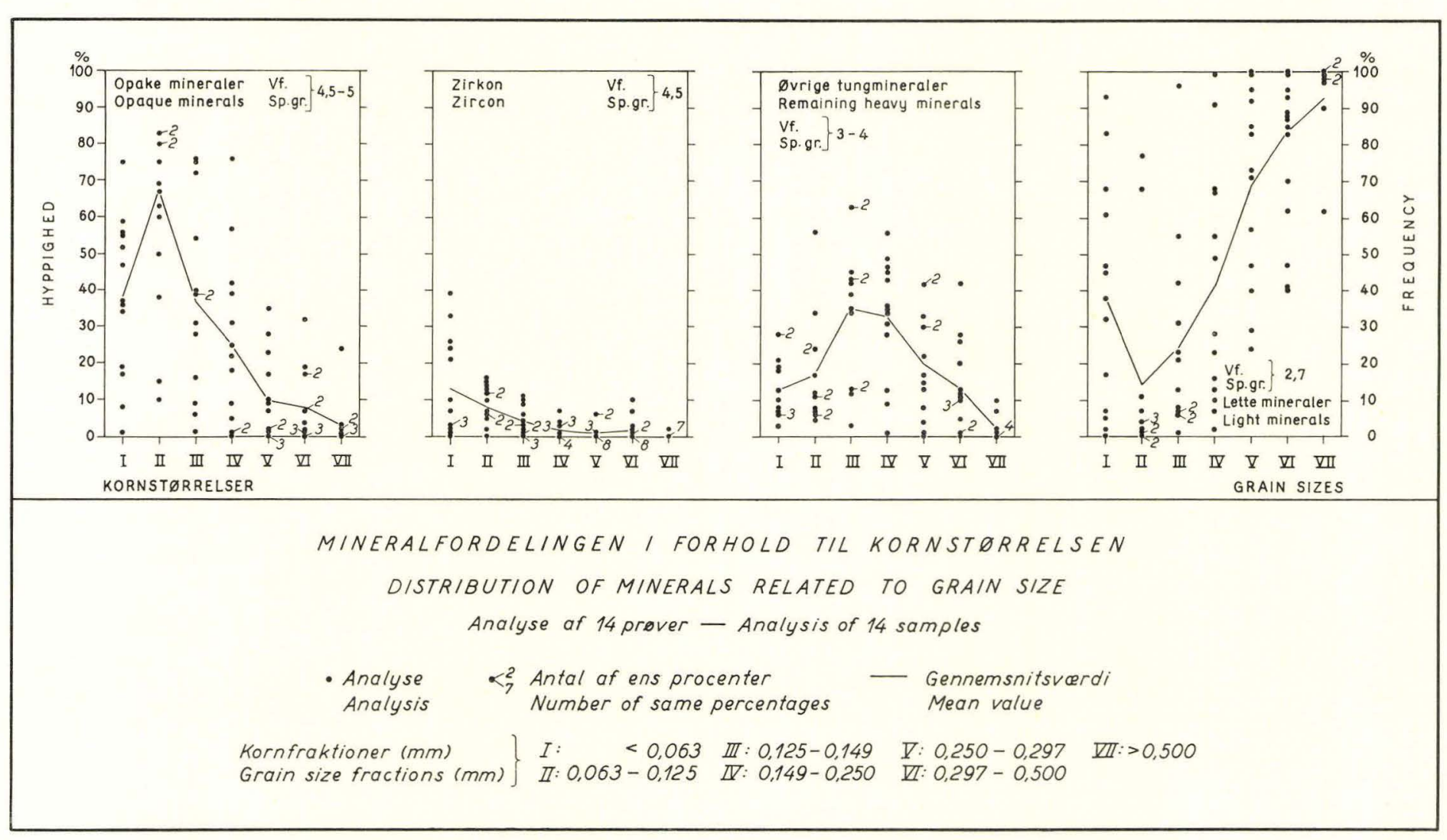




\section{GEOLOGISK VURDERING AF MINERAL- INDHOLDET}

De geologiske processer, som fører til tungsandsaflejringernes dannelse, har Werner Christensen redegjort for andetsted i afhandlingen (p. 25). De geologiske forhold, som afspejles i mineralernes fordeling, skal belyses i det følgende.

\section{Regionale variationer i tungmineralselskabet.}

B e d $\phi \mathrm{mm}$ e l s e s b a s is.

De forskellige forekomster indeholder i hovedsagen samme slags mineraler, men mineralernes mængdeforhold er underkastet betydelige variationer. Disse variationer er delvis betinget af forskelle i tungmineralkoncentrationen (se fig. 5, p. 38). Ved vurdering af mineralselskabernes regionale variationer er derfor af hensyn til overskueligheden kun de bedst koncentrerede materialer, d. v. s. prøver med tungmineralindhold $>50 \%$, anvendt som bed $\varnothing$ mmelsesbasis.

Diagrammet fig. 7 viser tungmineralfraktionens sammensætning med hensyn til 1) magnetit, 2) ilmenit og 3) non-opake mineraler. Fig. 8 viser den non-opake fraktions sammensætning med hensyn til 1) zirkon, rutil, titanit, monazit, turmalin, 2) granat, staurolit, cyanit, sillimanit og 3) epidot, amfibol, pyroxen, alterit. I diagrammerne er tungmineralprocentens størrelsesorden angivet med signatur for hver analyse.

Diagrammerne afspejler følgende generelle træk.

1. Næsten samtlige analyser falder inden for et velafgrænset område i diagrammerne.

2. Hvor der er flere prøver fra samme forekomst er der som regel nogen spredning i analyseresultaterne; men spredningen synes ofte betinget af forskelle i tungmineralprocenten, idet der med stigning i denne er tendens til

a) stigning $i$ indholdet af opak malm samt stigning $i$ forholdet magnetit: ilmenit (fig. 7) b) stigning i såvel summen af som forholdet mellem 1) zirkon m.m. og 2) granat m.m. (fig. 8; se også fig. 5, p. 38). 
De regionale variationer.

Idet ovennævnte forhold tages i betragtning, kan mineralselskaberne inddeles i følgende udbredelsesområder

\begin{tabular}{|c|c|c|}
\hline \multicolumn{2}{|c|}{ Karakteristik af mineralselskab } & \multirow{2}{*}{ Område } \\
\hline Non-opak & Opak & \\
\hline Zirkon helt dominerende & Stort indhold & Bornholm (ved Arnager) \\
\hline \multirow{3}{*}{ Zirkon stærkt fremtrædende } & $\begin{array}{l}\text { Stort indhold; ilmenit } \\
\text { dominerende }\end{array}$ & Tertiæret ved Holstebro \\
\hline & $\begin{array}{l}\text { Stort indhold; ilmenit } \\
\text { dominerende }\end{array}$ & Ostjylland (ved Saksild) \\
\hline & $\begin{array}{l}\text { Stort indhold; næsten lige dele } \\
\text { ilmenit og magnetit }\end{array}$ & $\begin{array}{l}\text { Jyllands vestkyst ved Fjal- } \\
\text { tring og ud for Nissum Fjord }\end{array}$ \\
\hline Granat helt dominerende & $\begin{array}{l}\text { Lille indhold; ilmenit } \\
\text { dominerende }\end{array}$ & Sydlolland (ved Rødbyhavn) \\
\hline \multirow[t]{2}{*}{ Granat stærkt fremtrædende } & $\begin{array}{l}\text { Stort indhold; næsten lige dele } \\
\text { ilmenit og magnetit }\end{array}$ & $\begin{array}{l}\text { Nordsjælland samt Røgle- } \\
\text { området på Nordfyn }\end{array}$ \\
\hline & $\begin{array}{l}\text { Ret lille indhold; ilmenit } \\
\text { næsten eneherskende }\end{array}$ & $\begin{array}{l}\text { Jyllands vestkyst fra Sund- } \\
\text { huse til Lyngvig }\end{array}$ \\
\hline $\begin{array}{l}\text { Epidot og hornblende ret } \\
\text { stærkt fremtrædende }\end{array}$ & $\begin{array}{l}\text { Lille indhold; ilmenit næsten } \\
\text { eneherskende }\end{array}$ & Skagen og Kandestederne \\
\hline $\begin{array}{l}\text { Intermediær m.h.t. zirkon, } \\
\text { granat og epidot-hornblende }\end{array}$ & $\begin{array}{l}\text { Stort indhold; næsten lige dele } \\
\text { ilmenit og magnetit }\end{array}$ & Skallerup-Lønstrup \\
\hline
\end{tabular}

Dertil kommer mineralselskabet i Thyborøn-Vrist området. Dette synes nærmest at kunne betragtes som et overgangsled mellem selskabet i Fjaltring- og det i Sundhuse-Lyngvig-området.

Tavle VIII viser udsnit af mineralselskabet i forskellige forekomster.

Holdbarheden af denne opdeling i mineralprovinser er f $\varnothing$ rst og fremmest afhængig af det unders $\varnothing$ gte materiales repræsentativitet. Som tidligere nævnt (p. 31) har vi ikke på forhånd kendskab hertil, på grund af at materialet ikke er indsamlet systematisk. - I de tilfælde, hvor der foreligger flere prøver fra samme forekomst, er mineralfordelingen imidlertid i hovedsagen ens i materialer med samme tungmineralkoncentration (se bl. a. fig. 7 og 8). Dertil kommer, at ForcHHAMMER's angivelse af, at ilmenit var stærkt fremtrædende i sandet ved Skagen for ca. 120 år siden, samt RøврAм's konstatering, at magnetit var rigeligt til stede i sandet på Nordsjællands kyst i 1890’erne, er udmærket overensstemmende med de foreliggende unders $\emptyset$ gelser. De her nævnte forhold tyder på, at hovedtrækkene i den ovenfor skitserede mineralfordeling er rigtig. Fortsatte studier må imidlertid påregnes at ville medføre revisioner med hensyn til provinsernes udbredelse og indbyrdes grænseforhold. 
Variation ernes års g.

Det kan være nærliggende at søge årsagen til mineralselskabernes regionale variationer i udgangsmaterialets sammensætning i de forskellige områder. Der g $\phi \mathrm{r}$ sig imidlertid også andre forhold gældende, hvilket skal belyses i det følgende.

Ved Fjaltring og Lønstrup-Skallerup findes tungsandsaflejringer i nær tilknytning til nedbrydningsområder, henholdsvis Bovbjerg og Lønstrup klint. Forekomsternes mineraler må antages overvejende at stamme fra materialet i disse nedbrydningsområder. Disse mineralforekomster kan derfor betegnes »proximale«. Fælles for begge tungsandsaflejringers mineralselskab er det store indhold af malmkorn, repræsenteret ved næsten lige dele magnetit og ilmenit. Tilsvarende forhold mellem magnetit og ilmenit træffes endvidere i tungsandet i Nordsjælland samt ved Røjle Klint på Nordfyn. På begge disse kyster findes klinter med istidsaflejringer ved eller i nærheden af tungsandsforekomsterne.

De store forekomster ved Skagen og Kandestederne samt ved Lyngvig på Holmslands klit findes derimod på marine sandtanger, opbygget af materiale, som strøm og bølger har tilf $\phi$ rt fra henholdsvis syd og nord. Tungsandets mineraler må derfor være transporteret betydelige strækninger, før de blev koncentreret i de nuværende forekomster, som derfor kan betegnes »distale«. Fælles for mineralindholdet i de nævnte forekomster er, at magnetit kun findes i ganske ringe mængde.

Disse forhold tyder på, at der ved mineralkornenes transport langs kysten foregår en selektiv sortering, således at de tungeste korn (magnetit) overvejende ophobes nærmest oprindelsesstedet, medens de lettere korn kan transporteres længere bort. - Principielt tilsvarende forhold omtaler GARDNER (1952) fra Australien.

Skagenområdets extremt ringe indhold af malme og ret store indhold af de lette tungmineraler epidot og hornblende er sandsynligvis et resultat af en vidtgående mineralseparation under materialvandringen.

Udgangsmaterialets sammensæțing må imidlertid også influere på de regionale variationer. Dette fremgår tydeligst ved sammenligning af forskellige »proximale« forekomster, f. eks. forekomsterne i Fjaltringområdet og i Nordsjælland. Førstnævnte område er karakteriseret ved et stort indhold af zirkon, medens dette mineral kun findes i ringe mængde i Nordsjælland.

Det principielle i de her nævnte forhold kan sammenfattes på f $\varnothing \mathrm{l}$ gende måde: 


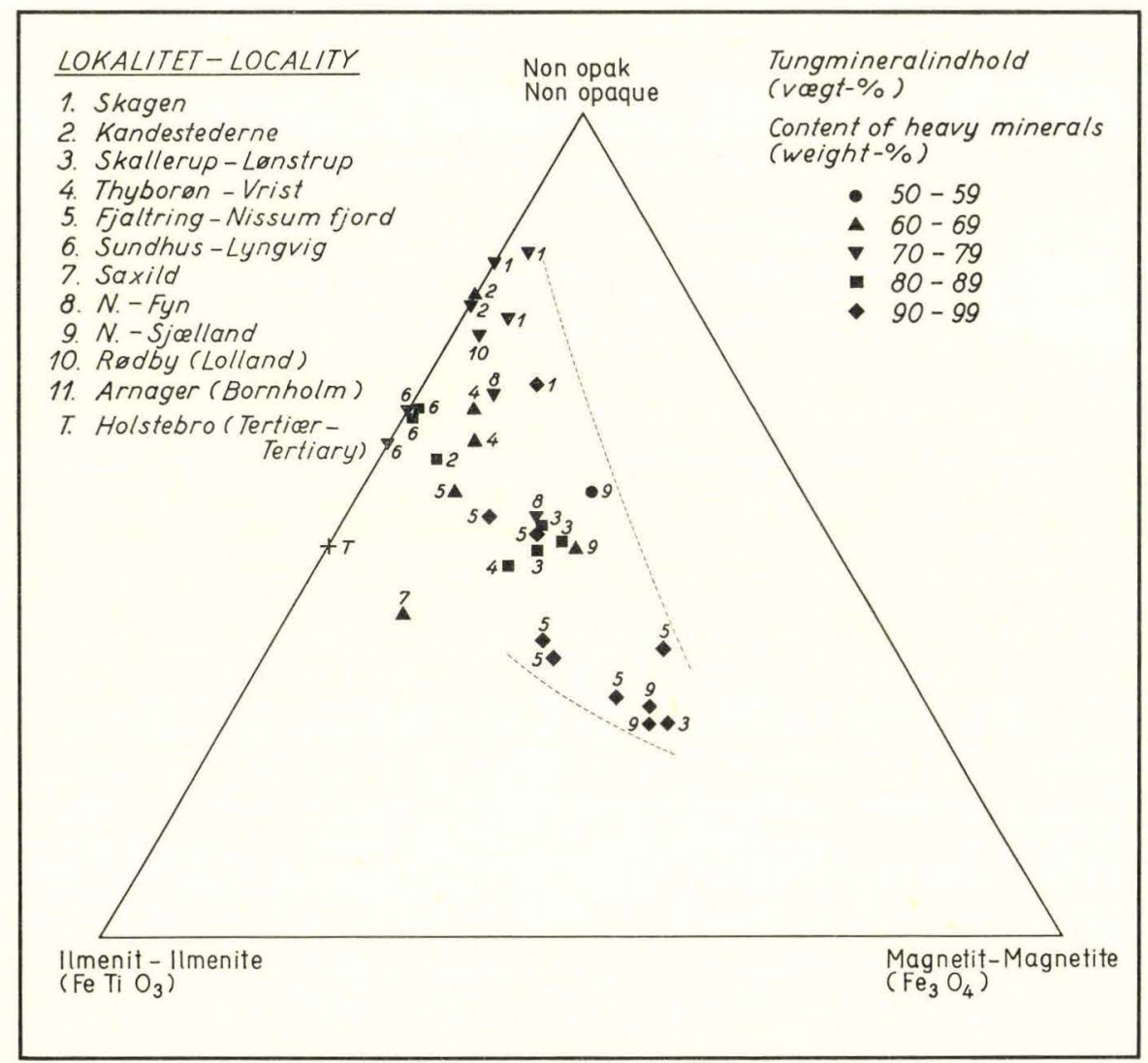

Fig. 7. Tungmineralfraktionens sammensætning med hensyn til magnetit, ilmenit og non-opake mineraler i højtkoncentrerede prøver.

1. De »proximale« forekomsters sammensætning er betinget af a) udgangsmaterialets sammensætning og b) separationen under koncentrationsprocessen.

2. De »distale« forekomsters sammensætning er betinget af a) udgangsmaterialets sammensætning, b) separationen under materialvandringen og c) separationen under koncentrationsprocessen.

Praktiske resultater.

Kendskabet til mineralselskabernes regionale variationer og disses årsager er af indlysende grunde betydningsfuldt for en vurdering af tungsandsforekomsternes udnyttelsesmuligheder.

De mineraler, der primært anses for økonomisk vigtige er malmene magnetit og ilmenit samt mineralet zirkon (se p. 55). For de store tungsandsforekomster, hvis mineralindhold er unders $\varnothing$ gt, er der i f $\varnothing$ l- 


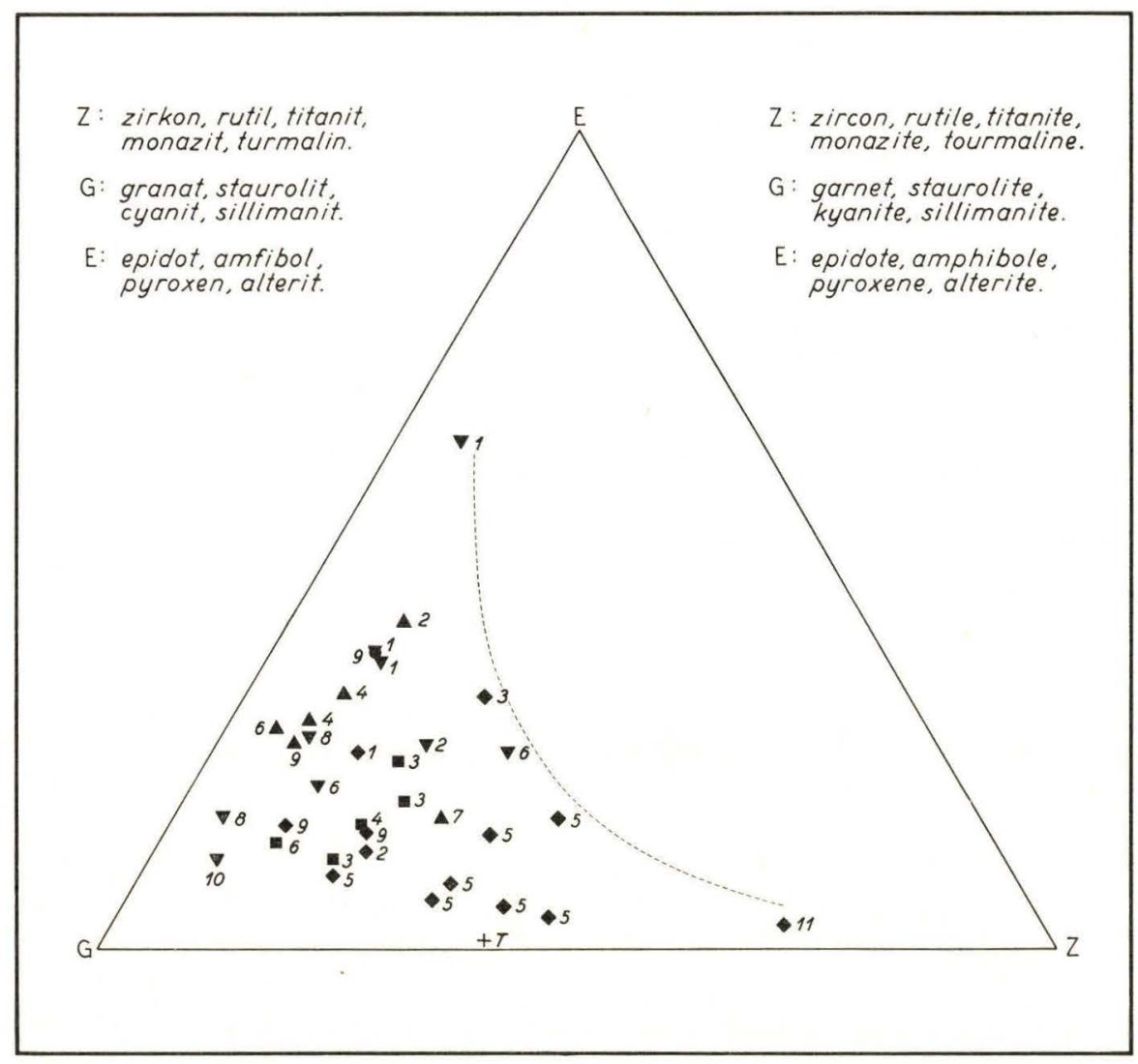

Fig. 8. Den non-opake tungmineralfraktions sammensætning med hensyn til $Z$, G og E (se forklaringen i figuren) i højtkoncentrerede prøver. Signaturer og talbetegnelser som i fig.7.

gende tabel angivet det gennemsnitlige indhold af disse mineraler i den tunge fraktion i højtkoncentrerede materialer, d. v. s. prøver med mere end $50 \%$ tungmineraler. I tabellen er forekomsternes karakter af proximale eller distale dannelser angivet.

Denne sammenstilling viser, at de proximale forekomster generelt set repræsenterer de med hensyn til sammensætning bedst egnede udgangsmaterialer for en mineralproduktion, idet koncentrationen af værdistoffer er størst her. Det, der især er udslagsgivende i denne forbindelse, er magnetitindholdet. Som magnetitmalme er proximalforekomsterne langt bedre egnede end distalforekomsterne, medens de to typer står nogenlunde lige, som ilmenitmalme betragtet. Med hensyn til zirkon er forholdene noget anderledes, idet samtlige her nævnte jyske forekomster må anses for gode udgangsmaterialer for udvinding af dette mineral, medens forekomsterne i Nordsjælland er betydelig ringere. 


\begin{tabular}{|c|c|c|c|c|c|}
\hline \multirow{2}{*}{ Forekomst } & \multirow{2}{*}{ Karakter } & \multicolumn{4}{|c|}{$\begin{array}{l}\text { Gennemsnitlig hyppighed af okonomiske mineraler } \mathrm{i} \\
\text { højtkoncentrerede provers tungmineralfraktion }\end{array}$} \\
\hline & & Magnetit & Ilmenit & Zirkon & Sum \\
\hline Fjaltring........ & proximal & $29 \%$ & $32 \%$ & $9 \%$ & $70 \%$ \\
\hline Skallerup-Løn- & & & & & \\
\hline strup $\ldots \ldots \ldots$ & proximal & $28 \%$ & $29 \%$ & $6 \%$ & $63 \%$ \\
\hline Nordsjælland ... & proximal & $34 \%$ & $27 \%$ & $2 \%$ & $63 \%$ \\
\hline Lyngvig . . . . . . . & distal & $0 \%$ & $38 \%$ & $7 \%$ & $45 \%$ \\
\hline Kandestederne .. & distal & $2 \%$ & $27 \%$ & $10 \%$ & $39 \%$ \\
\hline Skagen........ & distal & $5 \%$ & $18 \%$ & $6 \%$ & $29 \%$ \\
\hline
\end{tabular}

Såfremt de her nævnte relationer er udtryk for geologiske lovmæssigheder, må det være muligt ud fra kendskabet til en given forekomsts geologiske beliggenhed og beliggenhed i forhold til nedbrydningsområdet, at skønne nogenlunde sikkert om dens indhold af $\varnothing$ konomiske mineraler.

Tungsandsforekomsten ved Uggerby $\varnothing$ st for Hirtshals er et eksempel på en større aflejring, som endnu ikke er undersøgt mineralogisk. Dens sammensætning kan imidlertid skønnes således. På grund af at forekomsten er beliggende i det nordjyske område kan zirkonindholdet antages at være ret stort. Forekomsten er ifølge feltobservationerne (se p. 15) nærmest af proximal type. Den må derfor antages at indeholde betydelige mængder af både magnetit og ilmenit. - Det skal i denne forbindelse nævnes, at de p. 52 angivne kemiske analyser af magnetseparerede pr $\phi$ ver viser, at en prøve fra Uggerby indeholdt $14,2 \%$ stærkt magnetisk materiale med et $\mathrm{Fe}_{3} \mathrm{O}_{4}$-indhold på 93,8 \% .

\section{Materialets oprindelse.}

Ved koncentrationsprocessen er det oprindelige mængdeforhold mellem de forskellige mineraler ændret (se p. 38). Da tungsandets sammensætning således ikke afspejler enkeltheder i udgangsmaterialets sammensætning, skal der i det følgende kun fremsættes generelle betragtninger vedrørende dette materiales oprindelse.

For størstedelen af tungsandsforekomsterne må udgangsmaterialet antages at repræsentere kvartære aflejringer, som for en stor del er tilf $\varnothing$ rt fra Skandinavien af istidens gletschere. If $\varnothing$ lge den gældende opfattelse er det nordlige Danmark stærkt præget af is fra Norge, medens Midt- og Syddanmark væsentligst har fået tilf $\emptyset \mathrm{rt}$ materiale fra Mellem- og Sydsverige samt det baltiske område.

Mineralerne i forekomsterne ved Skagen, Kandestederne og Lønstrup-Skallerup må derfor antages væsentligst at stamme fra Norge. 
Det er dog muligt, at nedre kridt- og juraaflejringer, som $\emptyset$ jensynlig har været blotlagt i Skagerrak og det nordligste Jylland i kvartærtiden, (se Skeat \& Madsen, 1898; Gregersen \& Sorgenfrei, 1951) har leveret en del af materialet.

Tungsandets mineraler i det фvrige Jylland og på фerne må sandsynligvis overvejende hidrøre fra Sverige og Balticum. En del af det jyske materiale indeholder dog sikkert mineraler fra de tertiære sandaflejringer, oparbejdet i istidsaflejringerne ved gletschernes passage over Jylland. Ligheden mellem tertiærforekomsten ved Holstebro og de recente dannelser ved Fjaltring på Jyllands vestkyst og ved Saxild på østkysten tyder herpå. De tertiære sandaflejringer stammer imidlertid også oprindelig fra Skandinavien (se G. Larsen og A. Dinesen, 1959). Materialet i forekomsterne på Fyn, Sjælland og Lolland skal sikkert afledes direkte fra Skandinavien. Disse aflejringer afviger da også, især i zirkonindholdet, en del fra de jyske.

Det meget zirkonrige sand på Bornholms sydkyst er sandsynligvis overvejende af lokal oprindelse. Denne antagelse grunder sig på det forhold, at tungmineralerne i en del af Bornholms ældre sedimenter, bl. a. Nex $\varnothing$ sandstenen, næsten udelukkende består af zirkon (se H. Gry, 1936). 


\section{TUNGSANDETS \\ UDNYTTELSESMULIGHEDER}

Forudsætningen for udnyttelsen af de danske tungsandsforekomster vil være afhængig af

1. Mængde og koncentration.

2. Indhold af værdistoffer og disses kvalitet.

\section{Mrengde og koncentration.}

I forhold til de oversøiske forekomster af tungsand må man erkende, at de kendte danske forekomster er forsvindende små.

På den anden side findes en betydelig del af tungsandet ved vore kyster i meget fine koncentrationer, idet store mængder af tungsandet ved en omhyggelig opsamling kan fås med et indhold på omkring $90 \%$ tungmineral. (Dette er vist i praksis, da en vognmand leverede en vognladning på 20 tons med et indhold på $95 \%$ tungmineraler). Set på baggrund af de koncentrationer, man finder opgivet for oversøiske tungsandsforekomster, er det meget. I en meget udførlig rapport om omfattende unders $\emptyset$ gelser i $\emptyset$ st-Australien (GARDNER 1955) skelnes der mellem sand, der indeholder $300 \mathrm{lbs} / \mathrm{cubic}$ yard (ca. 180 $\mathrm{kg} / \mathrm{m}^{3}$ ) tungmineraler, 120-300 lbs/cubic yard og under $120 \mathrm{lbs} /$ cubic yard (ca. $70 \mathrm{~kg} / \mathrm{m}^{3}$ ). Da $1 \mathrm{~m}^{3}$. sand vejer over 2 tons, vil man se, at man her overvejende arbejder med koncentrater med under $10 \%$ tungmineral. Ved beregninger over mineralreserver medtages forekomster med under $5 \%$ tungmineral.

I en oversigt (Wessel 1958) over zirkonforekomster i U.S. A.'s syd $\varnothing$ stlige del anf $\varnothing$ res forekomster med 1.5 til $4.5 \%$ tunge mineraler og ca. $0.5 \%$ zirkon.

Ved de foretagne unders $\varnothing$ gelser over vort hjemlige tungsand er der ikke foretaget systematiske opmålinger af mængder, og sådanne kan derfor kun opgives efter et meget løseligt sk $\phi$ n.

Går man ud fra de større, samlede forekomster, da strækker de sig vel over 20 à $25 \mathrm{~km}$ strandbred. Vil man i f $\phi$ rste række kun interessere sig for det tungsand, der indeholder over $50 \%$ tungmineraler, da kan man vel i gennemsnit regne med ca. $2 \mathrm{~m}^{3}$ sand pr. løbende meter strandbred, svarende til ca. 5 tons pr. løbende meter eller ialt 
noget over 100.000 tons tungsand med omkring 70.000 tons tungmineral. Går man ud fra koncentrater med mindst $70 \%$ tungmineral, bliver det næppe mere end det halve. Dertil kommer alle de spredte, mindre forekomster langs kysterne, hvor man ofte kan finde gode koncentrater samt de store mængder af tungsand i tynde lag og svage koncentrater, der har mulighed for under gunstige forhold at koncentreres. Hertil kommer eventuel tilførsel af nyt materiale.

\section{Indhold af værdistoffer og disses kvalitet.}

Ved udnyttelsen af det danske tungsand må interessen i f $\phi$ rste række samle sig om malmmineralerne samt zirkon og granat. Af omtalen af de første undersøgelser fremgår det, at malmmineralernes (de opake mineralers) sammensætning blev beregnet ud fra en kemisk analyse af tungsandet. For at få malmmineralerne i opløsning blev det fint pulveriserede tungsand smeltet med kaliumpyrosulfat, og i smeltemassen blev der foretaget bestemmelser af jern og titan. Da en mikroskopisk undersøgelse af smeltemassen ikke tydede på, at granater $\mathrm{m}$. m. blev angrebet ved smeltningen, blev der foretaget en beregning af indholdet af ilmenit $\left(\mathrm{FeTiO}_{3}\right)$ og magnetit $\left(\mathrm{Fe}_{3} \mathrm{O}_{4}\right)$, hvad der svarede til at Ti fandtes i ilmenit og overskuddet af jern var til stede i form af magnetit (se tabellen side 36). Selv om vi var klare over, at de enkelte sandskorn ikke altid var rene mineraler, regnede vi ikke med at indholdet af de på den måde beregnede mineralindhold ville ligge langt fra det virkelige.

Nogle op arbejdningsfors $\phi$ g.

Selve fraktioneringen af tungsandet er et teknisk spørgsmål, og når denne $\mathrm{i}$ det følgende diskuteres sammen med analyser af fraktioneringsprodukterne, er det kun fordi man derigennem kan få kendskab til mineralsammensætningen og variationen af denne i de enkelte fraktioner ved forskellig separeringsmetode og fra forskellige lokaliteter og derved også til de enkelte mineralers renhed. Som det vil fremgå af det følgende støtter vurderingen sig også til nogle fore. tagne mikroskopiske unders $\varnothing$ gelser af pelerpr $\varnothing$ ver af malmsandet.

I foråret 1958 fik firmaet A. LAUnSEN foretaget fraktioneringsfors $\varnothing \mathrm{g}$ af tungsandsprøver udtaget af et parti på ca. 20 tons fra stranden ved Skallerup. Den første undersøgelse blev foretaget af Sturtevant Engineering Company Ltd., London, der om fraktioneringen skriver, at de først lod hele prøven passere en elektrostatisk separator. Derefter blev fraktionen med magnetit og ilmenit delt ved magnetisk separation.

Den svagtmagnetiske fraktion, der bl. a. indeholdt zirkon, blev opdelt i flere fraktioner ved at passere en magnetisk separator. 
Det procentiske indhold af de enkelte ved opdelingen fremkomne fraktioner var opgivet som nedenfor anf $\varnothing$ rt.

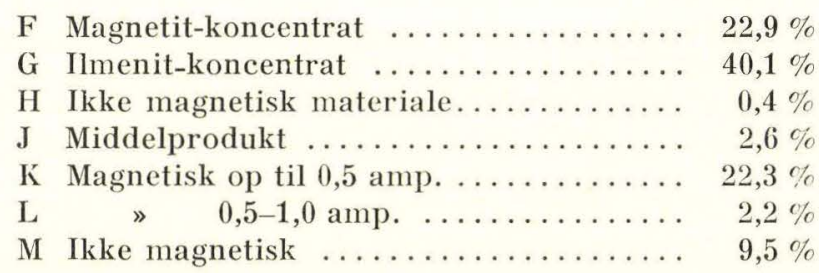

Gunnar Larsen udførte petrografiske analyser på de enkelte fraktioner, og på kemisk laboratorium blev der udført kemiske analyser på fraktionerne F og G. Ud fra disse unders $\varnothing$ gelser kan man danne sig en mening om koncentration og renhed af de $\emptyset$ konomiske mineraler i hovedfraktionerne.

Fraktion F: ca. $100 \%$ opak mineral med $68,6 \% \mathrm{Fe}$

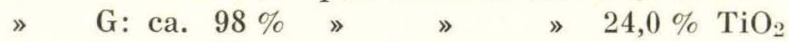

» $\mathrm{K}:$ ca. $86 \%$ granat, ca. $8 \%$ opak

» $\quad$ : ca. $27 \%$ zirkon, ca. $6 \%$ opak (53\% kvarts, $6 \%$ feldspat)

Da magnetit indeholder $72,4 \% \mathrm{Fe}$, er renheden i $\mathrm{F}$ ret god; men da rent ilmenit indeholder $53,4 \% \mathrm{TiO}_{2}$ kan man se, at fraktion med sine $24 \% \mathrm{TiO}_{2}$ er et meget dårligt ilmenit-koncentrat.

Senere på året fik vi overladt en rapport udarbejdet af Institutionen för Anrikning, Kung. Tekniska Högskolan, Stockholm, om undersøgelse af tilsvarende tungsandsprøve. Ved denne undersøgelse blev der også udført mikroskopisk strukturunders $\varnothing$ gelse på polerpr $\varnothing v e r$, og af disse fremgik det, at malmmineralerne bestod af hæmatit, ilmenit og magnetit, og at ilmenit og hæmatit for en stor del optrådte sammen som indeslutninger i de respektive mineraler, og at dette også var tilfældet for hæmatit respektiv magnetit.

Ved magnetisk separation var der opnået følgende:

\begin{tabular}{|c|c|}
\hline Magnetit-fraktion & $20,6 \% \operatorname{med} 67,8 \% \mathrm{Fe} ; 3,3 \% \mathrm{TiO}_{2}$ \\
\hline Ilmenit-hæmatit ....... & $37,0 \% \quad 24,9 \% \mathrm{TiO}_{2}$ \\
\hline Granat m. m. ........ & $31,7 \%$ \\
\hline Umagnetisk $\ldots \ldots \ldots$ & $10,7 \%$ med $34 \%$ zirkon \\
\hline
\end{tabular}

I foråret 1959 er der på kryolitselskabet Øresund under dr. phil. H. PAULYs ledelse foretaget fors $\phi$ g med separering af nogle tungsandspr $\phi$ ver, deriblandt også af det samme parti fra Skallerup som anvendt til ovennævnte fors $\phi \mathrm{g}$. Der blev dels foretaget sortering af større pr $\varnothing$ ver med elektromagneter, som de anvendes i driften, dels ved laboratoriefors $\emptyset$ g.

Til sammenligning med ovenstående angives resultaterne af sorteringen af den store prøve tungsand, udtaget af samme parti. De kemiske analyser af malmsandet er foretaget på D. G. U.'s kemiske laboratorium.

\begin{tabular}{|c|c|}
\hline Magnetit $\ldots \ldots \ldots \ldots$ & $22,2 \%$ med $67,0 \% \mathrm{Fe}, 1,3 \% \mathrm{TiO}_{2}$ \\
\hline Ilmenit-hæmatit & $32,1 \% \quad 21,1 \% \mathrm{TiO}_{2}$ \\
\hline Granat m.m. ........ & $36,1 \%$ \\
\hline Umagnetisk ......... & $9,3 \%$ med ca. $34 \%$ zirkon. \\
\hline
\end{tabular}


Sammenligner man resultaterne fra de forskellige fraktionsfors $\emptyset$, er der nogen variation såvel $\mathrm{i}$ det samlede indhold af malmmineraler (London $63 \%$, Stockholm $58 \%$, Kryolitselskabet $54 \%$ ) som i indholdet af $\mathrm{TiO}_{2}$ i ilmenit-hæmatit-fraktionen, og det synes, som om den sortering, der giver st $\varnothing$ rste malmudbytte, også har det højeste indhold af $\mathrm{TiO}_{2}$.

I forbindelse med undersøgelesrne af prøverne på Kryolitselskabet »Øresund « foretog dr. H. PAUly også mikroskopiske undersøgelser af malmsandet, og af disse fremgik det, at de enkelte korn, særlig i det svagtmagnetiske malmsand, består af en blanding af ilmenit, hæmatit og magnetit, svarende til resultaterne ved unders $\emptyset$ gelserne i Stockholm. Det samme var tilfældet for malmsandet i prøver fra forskellige andre lokaliteter, og bl. a. også i to prøver henholdsvis fra stranden syd for Klitgaarden ved Skagen og fra Fjaltring, der blev underkastet samme fraktioneringsfors $\phi \mathrm{g}$ som pr $\varnothing \mathrm{ven}$ fra Skallerup. Pauly anslog ud fra de mikroskopiske undersøgelser, at indholdet af $\mathrm{TiO}_{2}$ i ilmenit-hæmatit-fraktionen lå på mellem 20 og $25 \%$, altså betydeligt under halvdelen af indholdet i rent ilmenit, der indeholder 53,4 \% $\mathrm{TiO}_{2}$.

Kemisk analyse af magnetsepareret materiale.

Efter at have stiftet bekendtskab med disse udefra foretagne undersøgelser stod det klart, at de ved de tidligere unders $\phi$ gelser foretagne beregninger af indhold af magnetit og ilmenit ikke gav nogen vejledning for, hvad der kunne opnås ved magnetisk sortering af tungsandet, idet en meget stor del af kornene var en blanding af flere mineraler. Da forholdet mellem indholdet af jern og titan varierede meget stærkt i sandet fra lokalitet til lokalitet, fandt jeg, at det måtle have en vis interesse at få fremstillet fraktioner af stærkt mag-

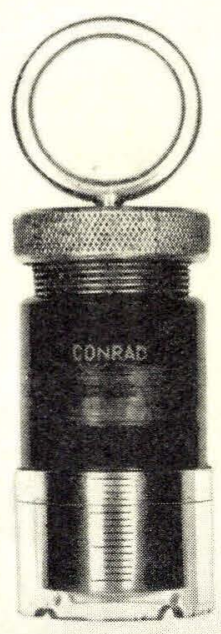
netisk og svagt magnetisk malm og at få foretaget kemiske analyser af sådanne fraktioner i prøver fra forskellige lokaliteter.

Resultaterne af en sådan undersøgelse fremgår af tabellen p. 52. Den magnetiske fraktionering er foretaget ved hjælp af en speciel permanent håndmagnet, der let kunne indstilles til forskellig afstand fra sandet, der spredtes ud på et underlag. Selve magneten hvilede i bundstilling på en tynd messingplade, hvorpå de magnetiske partikler hæftede sig. Ved at løfte magneten, slap messingbunden de magnetiske partikler. Ved hjælp af denne

Fig. 9. Magnet anvendt ved sortering af materiale til kemisk analyse. 
52 W. Christensen og G. Larsen: Tungsandsforekomster i Danmark.

\begin{tabular}{|c|c|c|c|c|c|c|c|c|c|c|c|c|}
\hline \multirow{2}{*}{ Forekomst } & \multirow{2}{*}{\begin{tabular}{l|}
$\dot{a}$ \\
0 \\
$\vdots$ \\
0 \\
$\vdots$ \\
2
\end{tabular}} & \multirow{2}{*}{ 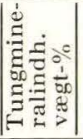 } & \multirow{2}{*}{\multicolumn{2}{|c|}{$\begin{array}{l}\text { Magnetiske frak- } \\
\text { tioner vægt-\% af } \\
\text { tung fraktion }\end{array}$}} & \multicolumn{8}{|c|}{ Kemisk sammensætning . Vægt-\% } \\
\hline & & & & & $\mathrm{FeTiO}_{3}$ & $\mathrm{Fe}_{3} \mathrm{O}_{4}$ & $\mathrm{Fe}_{2} \mathrm{O}_{0}$ & $\begin{array}{l}\text { Uopl. } \\
\text { rest }\end{array}$ & Sum & $\mathrm{Ti} 0_{2}$ & $\mathrm{Fe}$ & $\mathrm{Ti}$ \\
\hline $\begin{array}{l}\text { Skagen- } \\
\text { Hulsig }\end{array}$ & 87 & 93 & $\begin{array}{l}\text { st. m. } \\
\text { sv. m. } \\
\text { rest }\end{array}$ & $\begin{array}{r}0.7 \\
26.0 \\
73.3\end{array}$ & 48.1 & $\begin{array}{l}\text { ing } \\
- \\
\text { ing }\end{array}$ & $\begin{array}{l}\text { en anal } \\
47.5 \\
\text { en anal }\end{array}$ & $\begin{array}{l}\text { yse } \\
\text { yse } \\
\text { yse }\end{array}$ & 97.3 & 25.2 & 50.9 & 15.2 \\
\hline - & 88 & 84 & $\begin{array}{l}\text { st. m. } \\
\text { sv. m. } \\
\text { rest }\end{array}$ & $\begin{array}{r}2.0 \\
39.3 \\
58.7\end{array}$ & 46.1 & $\begin{array}{l}\text { ing } \\
\text { ing }\end{array}$ & $\begin{array}{c}\text { en anal } \\
51.1 \\
\text { en anal }\end{array}$ & $\begin{array}{l}\text { yse } \\
\text { yse }\end{array}$ & 98.8 & 24.3 & 52.7 & 14.6 \\
\hline 一 & K 10 & - & $\begin{array}{l}\text { magnetit } \\
\text { ilmenit- } \\
\text { hæmatit } \\
\text { granat }\end{array}$ & $\begin{array}{r}0.6 \\
8.1 \\
66.0\end{array}$ & $\begin{array}{l}12.1 \\
45.6 \\
16.0\end{array}$ & $\begin{array}{c}80.2 \\
- \\
-\end{array}$ & $\begin{array}{r}- \\
47.5 \\
11.4\end{array}$ & $\begin{array}{r}2.4 \\
4.3 \\
65.9\end{array}$ & $\begin{array}{l}94.7 \\
97.4 \\
\\
93.3\end{array}$ & $\begin{array}{r}6.4 \\
24.0 \\
\\
8.4\end{array}$ & $\begin{array}{l}62.5 \\
50.0 \\
\\
13.8\end{array}$ & $\begin{array}{r}3.8 \\
14.4\end{array}$ \\
\hline 一 & 99 & 99 & $\begin{array}{l}\text { st. } \mathrm{m} . \\
\text { sv. m. } \\
\text { rest }\end{array}$ & $\begin{array}{r}0.6 \\
8.9 \\
90.5\end{array}$ & 56.8 & $\begin{array}{l}\text { ing } \\
\overline{\text { ing }}\end{array}$ & $\begin{array}{c}\text { en anal } \\
28.2 \\
\text { en ana }\end{array}$ & $\begin{array}{l}\text { yse } \\
\text { yse } \\
\text { ys. }\end{array}$ & 90.8 & 29.9 & 40.7 & 17.9 \\
\hline $\begin{array}{l}\text { Kande- } \\
\text { stederne- } \\
\text { Råbjerg }\end{array}$ & 39 & 80 & $\begin{array}{l}\text { st. m. } \\
\text { sv. m. } \\
\text { rest }\end{array}$ & $\begin{array}{r}0.8 \\
13.0 \\
86.2\end{array}$ & 69.9 & $\begin{array}{l}\text { ing } \\
- \\
\text { ing }\end{array}$ & $\begin{array}{c}\text { en anal } \\
17.3 \\
\text { en anal }\end{array}$ & $\begin{array}{l}\text { yse } \\
\text { yse }\end{array}$ & 92.0 & 36.8 & 38.0 & 22.1 \\
\hline - & 84 & 71 & $\begin{array}{l}\text { st. m. } \\
\text { sv. m. } \\
\text { rest }\end{array}$ & $\begin{array}{r}0.6 \\
9.8 \\
89.6\end{array}$ & $\begin{array}{l}69.4 \\
13.9\end{array}$ & $\begin{array}{l}\text { ing } \\
- \\
-\end{array}$ & $\begin{array}{r}\text { en anal } \\
15.8 \\
3.6\end{array}$ & $\begin{array}{r}\text { yse } \\
6.9 \\
67.8\end{array}$ & $\begin{array}{l}92.1 \\
85.3\end{array}$ & $\begin{array}{r}36.6 \\
7.4\end{array}$ & $\begin{array}{r}36.6 \\
9.4\end{array}$ & $\begin{array}{r}21.9 \\
1.8\end{array}$ \\
\hline 一 & 86 & 79 & $\begin{array}{l}\text { st. } m . \\
\text { sv. m. } \\
\text { rest }\end{array}$ & $\begin{array}{r}0.6 \\
18.0 \\
81.4\end{array}$ & 71.6 & $\begin{array}{l}\text { ing } \\
\overline{\text { ing }}\end{array}$ & $\begin{array}{c}\text { en anal } \\
18.5 \\
\text { en anal }\end{array}$ & $\begin{array}{l}\text { yse } \\
\text { yse }\end{array}$ & 94.1 & 37.7 & 39.3 & 17.8 \\
\hline - & 97 & 76 & $\begin{array}{l}\text { st. m. } \\
\text { sv. m. } \\
\text { vest }\end{array}$ & $\begin{array}{r}0.7 \\
18.5 \\
80.8\end{array}$ & 64.1 & $\begin{array}{l}\text { ing } \\
\text { ing }\end{array}$ & $\begin{array}{l}\text { en anal } \\
25.0 \\
\text { en anal }\end{array}$ & $\begin{array}{l}\text { yse } \\
\text { yse }\end{array}$ & 92.8 & 33.7 & 41.1 & 20.2 \\
\hline Uggerby & 83 & 79 & $\begin{array}{l}\text { st. } \mathrm{m} . \\
\text { sv. m. } \\
\text { rest }\end{array}$ & $\begin{array}{l}14.2 \\
27.2 \\
58.6\end{array}$ & $\begin{array}{r}4.9 \\
49.8 \\
16.8\end{array}$ & $\begin{array}{c}93.8 \\
- \\
-\end{array}$ & $\begin{array}{r}- \\
42.1 \\
5.3\end{array}$ & $\begin{array}{r}0.8 \\
3.6 \\
68.6\end{array}$ & $\begin{array}{l}99.7 \\
95.5 \\
90.7\end{array}$ & $\begin{array}{r}2.6 \\
26.2 \\
8.8\end{array}$ & $\begin{array}{r}69.7 \\
47.8 \\
9.8\end{array}$ & $\begin{array}{r}1.5 \\
15.7 \\
5.3\end{array}$ \\
\hline $\begin{array}{l}\text { Skallerup- } \\
\text { Lønstrup }\end{array}$ & 69 & 97 & $\begin{array}{l}\text { st. m. } \\
\text { sv. m. I } \\
\text { sv. m. II } \\
\text { rest }\end{array}$ & $\begin{array}{l}27.3 \\
18.2 \\
18.4 \\
36.1\end{array}$ & $\begin{array}{r}4.6 \\
28.4 \\
54.4\end{array}$ & $\begin{array}{c}90.8 \\
- \\
- \\
\text { ing }\end{array}$ & $\begin{array}{r}- \\
64.9 \\
37.2 \\
\text { en ana }\end{array}$ & $\begin{array}{r}0.6 \\
1.1 \\
1.9 \\
\text { yse }\end{array}$ & $\begin{array}{l}96.0 \\
94.9 \\
93.5\end{array}$ & $\begin{array}{r}2.4 \\
15.0 \\
28.6\end{array}$ & $\begin{array}{l}67.5 \\
55.8 \\
46.0\end{array}$ & $\begin{array}{r}1.5 \\
9.0 \\
17.2\end{array}$ \\
\hline - & 79 & 99 & $\begin{array}{l}\text { st. m. } \\
\text { sv. m. } \\
\text { rest }\end{array}$ & $\begin{array}{l}37.8 \\
40.5 \\
21.7\end{array}$ & $\begin{array}{r}4.9 \\
37.9 \\
15.5\end{array}$ & $\begin{array}{c}93.2 \\
- \\
-\end{array}$ & $\begin{array}{c}- \\
58.0 \\
20.5\end{array}$ & $\begin{array}{r}0.4 \\
2.3 \\
58.7\end{array}$ & $\begin{array}{l}98.5 \\
98.2 \\
94.7\end{array}$ & $\begin{array}{r}2.6 \\
20.0 \\
8.2\end{array}$ & $\begin{array}{l}69.2 \\
54.5 \\
20.0\end{array}$ & $\begin{array}{r}1.5 \\
11.9 \\
4.9\end{array}$ \\
\hline 一 & 92 & 82 & $\begin{array}{l}\text { st. } m . \\
\text { sv. } m \text {. } \\
\text { rest }\end{array}$ & $\begin{array}{l}22.6 \\
30.6 \\
46.8\end{array}$ & $\begin{array}{r}5.3 \\
47.8\end{array}$ & $\begin{array}{c}93.0 \\
\overline{\text { ing }}\end{array}$ & $\begin{array}{r}- \\
46.4 \\
\text { en anal }\end{array}$ & $\begin{array}{r}0.5 \\
y^{2.0}\end{array}$ & $\begin{array}{l}98.8 \\
96.2\end{array}$ & $\begin{array}{r}2.8 \\
25.2\end{array}$ & $\begin{array}{l}69.2 \\
50.0\end{array}$ & $\begin{array}{r}1.7 \\
15.1\end{array}$ \\
\hline- & 95 & 86 & $\begin{array}{l}\text { st. m. } \\
\text { sv. m. } \\
\text { rest }\end{array}$ & $\begin{array}{l}21.9 \\
31.3 \\
46.8\end{array}$ & $\begin{array}{r}7.3 \\
46.4\end{array}$ & $\begin{array}{c}91.4 \\
- \\
\text { ing }\end{array}$ & $\begin{array}{c}- \\
45.9 \\
\text { en anal }\end{array}$ & $\begin{array}{r}0.6 \\
2.6 \\
\text { yse }\end{array}$ & $\begin{array}{l}99.3 \\
94.9\end{array}$ & $\begin{array}{r}3.8 \\
24.4\end{array}$ & $\begin{array}{l}68.8 \\
49.1\end{array}$ & $\begin{array}{r}2.3 \\
14.6\end{array}$ \\
\hline - & 98 & 97 & $\begin{array}{l}\text { st. } \mathrm{m} . \\
\text { sv. m. } \\
\text { rest }\end{array}$ & $\begin{array}{l}24.3 \\
34.6 \\
41.1\end{array}$ & $\begin{array}{r}4.1 \\
43.9\end{array}$ & $\begin{array}{c}95.4 \\
- \\
\text { ing }\end{array}$ & $\begin{array}{c}-\overline{-} \\
49.7 \\
\text { en anal }\end{array}$ & $\begin{array}{r}0.6 \\
y e^{1.4}\end{array}$ & $\begin{array}{r}100.1 \\
95.0\end{array}$ & $\begin{array}{r}2.2 \\
23.1\end{array}$ & $\begin{array}{l}70.6 \\
50.9\end{array}$ & $\begin{array}{r}1.3 \\
13.6\end{array}$ \\
\hline- & K 8 & - & $\begin{array}{l}\text { magnetit } \\
\text { ilmenit- } \\
\text { hæmatit } \\
\text { granat }\end{array}$ & $\begin{array}{l}22.2 \\
32.1\end{array}$ & $\begin{array}{r}4.1 \\
40.1 \\
6.1\end{array}$ & $\begin{array}{c}90.4 \\
-\end{array}$ & $5 \overline{3.0}$ & $\begin{array}{l}2.6 \\
3.4\end{array}$ & $\begin{array}{l}97.1 \\
96.5\end{array}$ & $\begin{array}{r}2.2 \\
21.1 \\
\\
3.2\end{array}$ & $\begin{array}{l}67.0 \\
51.8\end{array}$ & $\begin{array}{r}1.3 \\
12.6\end{array}$ \\
\hline
\end{tabular}




\begin{tabular}{|c|c|c|c|c|c|c|c|c|c|c|c|c|}
\hline \multirow{2}{*}{ Forekomst } & \multirow{2}{*}{$\begin{array}{l}\dot{a} \\
0 \\
0 \\
\overrightarrow{0} \\
\dot{\Delta} \\
\end{array}$} & \multirow{2}{*}{ 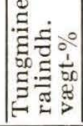 } & \multirow{2}{*}{\multicolumn{2}{|c|}{$\begin{array}{l}\text { Magnetiske frak- } \\
\text { tioner vægt-\% af } \\
\text { tung fraktion }\end{array}$}} & \multicolumn{8}{|c|}{ Kemisk sammensætning . Vægt - \% } \\
\hline & & & & & $\mathrm{FeTiO}_{3}$ & $\mathrm{Fe}_{3} \mathrm{O}_{4}$ & $\mathrm{Fe}_{2} \mathrm{O}_{3}$ & $\begin{array}{l}\text { Uopl. } \\
\text { rest }\end{array}$ & Sum & $\mathrm{Ti} 0_{2}$ & $\mathrm{Fe}$ & $\mathrm{Ti}$ \\
\hline Harboøre & 28 & 77 & $\begin{array}{l}\text { st. } m . \\
\text { sv. m. } \\
\text { rest }\end{array}$ & $\begin{array}{l}10.6 \\
31.7 \\
57.7\end{array}$ & $\begin{array}{l}10.6 \\
53.4\end{array}$ & $\begin{array}{c}84.7 \\
- \\
\text { ing }\end{array}$ & $\begin{array}{c}-\bar{c} \\
41.5 \\
\text { n anal }\end{array}$ & $\begin{array}{l}1.5 \\
2.7 \\
\text { yse }\end{array}$ & $\begin{array}{l}99.8 \\
97.8\end{array}$ & $\begin{array}{r}5.6 \\
28.1\end{array}$ & $\begin{array}{l}65.2 \\
48.7\end{array}$ & $\begin{array}{r}3.3 \\
16.9\end{array}$ \\
\hline 一 & 96 & 98 & $\begin{array}{l}\text { st. } m . \\
\text { sv. m. } \\
\text { rest }\end{array}$ & $\begin{array}{l}18.9 \\
41.7 \\
39.4\end{array}$ & $\begin{array}{r}9.7 \\
34.7\end{array}$ & $\begin{array}{c}88.3 \\
- \\
\text { ing }\end{array}$ & $\begin{array}{c}- \\
5 \overline{9} .0 \\
\text { anal }\end{array}$ & $\begin{array}{r}0.4 \\
y^{1.3}\end{array}$ & $\begin{array}{l}98.4 \\
94.2\end{array}$ & $\begin{array}{r}5.1 \\
18.3\end{array}$ & $\begin{array}{l}67.5 \\
54.1\end{array}$ & $\begin{array}{r}3.1 \\
11.0\end{array}$ \\
\hline Fjaltring & 80 & 99 & $\begin{array}{l}\text { st. } m . \\
\text { sv. m. } \\
\text { rest }\end{array}$ & $\begin{array}{l}30.0 \\
48.5 \\
21.5\end{array}$ & $\begin{array}{r}5.6 \\
29.4 \\
15.8\end{array}$ & $\begin{array}{c}91.0 \\
- \\
-\end{array}$ & $\begin{array}{c}- \\
64.7 \\
24.4\end{array}$ & $\begin{array}{r}1.6 \\
4.5 \\
54.6\end{array}$ & $\begin{array}{l}98.2 \\
98.6 \\
94.8\end{array}$ & $\begin{array}{r}2.9 \\
15.5 \\
8.3\end{array}$ & $\begin{array}{l}67.9 \\
56.1 \\
22.9\end{array}$ & $\begin{array}{l}1.8 \\
9.3 \\
5.0\end{array}$ \\
\hline - & 89 & 89 & $\begin{array}{l}\text { st. m. } \\
\text { mell. m. } \\
\text { sv. m. } \\
\text { rest }\end{array}$ & $\begin{array}{l}20.2 \\
16.0 \\
25.9 \\
37.9\end{array}$ & $\begin{array}{r}7.8 \\
8.5 \\
43.7\end{array}$ & $\begin{array}{c}89.9 \\
87.0 \\
- \\
\text { ing }\end{array}$ & $\begin{array}{c}- \\
(90.1) \\
52.4 \\
\text { en anal }\end{array}$ & $\begin{array}{r}0.4 \\
2.7 \\
3.7 \\
\text { yse }\end{array}$ & $\begin{array}{l}99.6 \\
98.2 \\
99.8\end{array}$ & $\begin{array}{r}4.1 \\
4.5 \\
23.8\end{array}$ & $\begin{array}{l}67.9 \\
66.1 \\
52.7\end{array}$ & $\begin{array}{r}2.4 \\
2.7 \\
13.8\end{array}$ \\
\hline - & 93 & 56 & $\begin{array}{l}\text { st. } m \text {. } \\
\text { sv. m. } \\
\text { rest }\end{array}$ & $\begin{array}{l}19.3 \\
31.8 \\
48.9\end{array}$ & $\begin{array}{l}15.8 \\
40.3\end{array}$ & $\begin{array}{c}79.6 \\
- \\
\text { ing }\end{array}$ & $\begin{array}{c}- \\
49.1 \\
\text { anal }\end{array}$ & $\begin{array}{r}0.8 \\
3.1 \\
\text { yse }\end{array}$ & $\begin{array}{l}96.2 \\
92.5\end{array}$ & $\begin{array}{r}8.3 \\
21.2\end{array}$ & $\begin{array}{l}63.4 \\
49.1\end{array}$ & $\begin{array}{r}5.0 \\
12.7\end{array}$ \\
\hline 一 & K 9 & - & $\begin{array}{l}\text { magnetit } \\
\text { ilmenit- } \\
\text { hæmatit } \\
\text { granat }\end{array}$ & $\begin{array}{l}22.6 \\
45.7 \\
24.7\end{array}$ & $\begin{array}{r}9.7 \\
34.2 \\
17.2\end{array}$ & $\begin{array}{c}90.1 \\
- \\
-\end{array}$ & $\begin{array}{c}\overline{-} \\
59.3 \\
19.0\end{array}$ & $\begin{array}{r}0.5 \\
4.8 \\
55.6\end{array}$ & $\begin{array}{r}100.3 \\
98.3 \\
91.8\end{array}$ & $\begin{array}{r}5.1 \\
18.0 \\
9.1\end{array}$ & $\begin{array}{l}67.0 \\
54.1 \\
\\
19.7\end{array}$ & $\begin{array}{r}3.1 \\
10.8\end{array}$ \\
\hline Fjande & 47 & 89 & $\begin{array}{l}\text { st. m. } \\
\text { sv. m. } \\
\text { rest }\end{array}$ & $\begin{array}{r}2.2 \\
29.5 \\
68.3\end{array}$ & 56.8 & $\begin{array}{c}\text { ing } \\
\overline{\text { ing }}\end{array}$ & $\begin{array}{c}\text { n anal } \\
36.5 \\
\text { n anal }\end{array}$ & $\begin{array}{l}\text { yse } \\
\text { yse } \\
\text { yse }\end{array}$ & 95.6 & 29.9 & 46.5 & 17.9 \\
\hline $\begin{array}{l}\text { Holmsland } \\
\text { Klit }\end{array}$ & 6 & 77 & $\begin{array}{l}\text { st. m. } \\
\text { sv. m. } \\
\text { rest }\end{array}$ & $\begin{array}{r}1.3 \\
18.0 \\
80.7\end{array}$ & 75.0 & $\begin{array}{l}\text { ing } \\
- \\
\text { ing }\end{array}$ & $\begin{array}{l}\text { n anal } \\
14.2 \\
\text { n anal }\end{array}$ & $\begin{array}{l}\text { yse } \\
\text { yse }\end{array}$ & 92.0 & 39.5 & 37.5 & 23.7 \\
\hline 一 & 54 & 66 & $\begin{array}{l}\text { st. } m \text {. } \\
\text { sv. m. } \\
\text { rest }\end{array}$ & $\begin{array}{r}1.5 \\
23.0 \\
75.5\end{array}$ & 70.4 & $\begin{array}{l}\text { ing } \\
\overline{\text { ing }}\end{array}$ & $\begin{array}{l}\text { n anal } \\
17.9 \\
\text { en anal }\end{array}$ & $\begin{array}{l}\text { yse } \\
\text { yse } \\
\text { ys. }\end{array}$ & 87.8 & 37.1 & 38.4 & 22.2 \\
\hline 一 & 61 & 95 & $\begin{array}{l}\text { st. m. } \\
\text { sv. m. I } \\
\text { sv. m. II } \\
\text { rest }\end{array}$ & $\begin{array}{r}2.6 \\
11.4 \\
23.0 \\
63.0\end{array}$ & $\begin{array}{l}54.9 \\
78.9\end{array}$ & $\begin{array}{l}\text { ing } \\
- \\
\text { ing }\end{array}$ & $\begin{array}{c}\text { en anal } \\
36.9 \\
11.5 \\
\text { anal }\end{array}$ & $\begin{array}{l}\text { yse } \\
0.9 \\
1.9 \\
\text { yse }\end{array}$ & $\begin{array}{l}92.7 \\
92.3\end{array}$ & $\begin{array}{l}28.9 \\
41.5\end{array}$ & $\begin{array}{l}46.0 \\
37.1\end{array}$ & $\begin{array}{l}17.3 \\
24.9\end{array}$ \\
\hline - & 90 & 84 & $\begin{array}{l}\text { st. } m \text {. } \\
\text { sv. m. } \\
\text { rest }\end{array}$ & $\begin{array}{r}3.8 \\
24.4 \\
71.8\end{array}$ & 68.2 & $\begin{array}{l}\text { ing } \\
\overline{\text { ing }}\end{array}$ & $\begin{array}{l}\text { n anal } \\
23.5 \\
\text { anal }\end{array}$ & $\begin{array}{l}\text { yse } \\
\text { yse } \\
\text { yse }\end{array}$ & 93.5 & 35.9 & 41.5 & 21.5 \\
\hline - & 91 & 78 & $\begin{array}{l}\text { st. } m \text {. } \\
\text { sv. m. } \\
\text { rest }\end{array}$ & $\begin{array}{r}1.6 \\
23.1 \\
75.3\end{array}$ & 75.5 & $\begin{array}{l}\text { ing } \\
\overline{\text { ing }}\end{array}$ & $\begin{array}{l}\text { n anal } \\
16.5 \\
\text { n anal }\end{array}$ & $\begin{array}{l}\text { yse } \\
\text { yse } \\
\text { ys. }\end{array}$ & 93.7 & 39.8 & 39.3 & 23.8 \\
\hline - & 94 & 28 & $\begin{array}{l}\text { st. m. } \\
\text { sv. m. } \\
\text { rest }\end{array}$ & $\begin{array}{r}1.2 \\
16.0 \\
82.8\end{array}$ & 68.5 & $\begin{array}{l}\text { ing } \\
\overline{\text { ing }}\end{array}$ & $\begin{array}{c}\text { n anal } \\
16.4 \\
n \text { anal }\end{array}$ & $\begin{array}{l}\text { yse } \\
\text { yse }\end{array}$ & 89.6 & 36.1 & 36.6 & 21.6 \\
\hline - & 100 & 71 & $\begin{array}{l}\text { st. m. } \\
\text { sv. m. } \\
\text { rest }\end{array}$ & $\begin{array}{r}1.1 \\
18.6 \\
80.3\end{array}$ & 74.4 & $\begin{array}{l}\text { ing } \\
\overline{\text { ing }}\end{array}$ & $\begin{array}{l}\text { n anal } \\
12.0 \\
n \text { anal }\end{array}$ & $\begin{array}{l}\text { yse } \\
\text { yse } \\
\text { ys. }\end{array}$ & 89.7 & 39.2 & 35.7 & 23.4 \\
\hline Liseleje & 5 & 94 & $\begin{array}{l}\text { st. m. } \\
\text { mell. m. } \\
\text { sv. m. } \\
\text { rest }\end{array}$ & $\begin{array}{l}27.0 \\
24.5 \\
14.3 \\
34.2\end{array}$ & $\begin{array}{r}7.5 \\
43.9 \\
57.8\end{array}$ & $\begin{array}{c}91.2 \\
(49.9) \\
- \\
\text { ing }\end{array}$ & $\begin{array}{c}- \\
51.6 \\
33.5 \\
\text { en anal }\end{array}$ & $\begin{array}{c}0.8 \\
1.7 \\
2.3 \\
\text { yse }\end{array}$ & $\begin{array}{c}99.5 \\
97.2 \\
93.6\end{array}$ & $\begin{array}{l}4.0 \\
23.1 \\
30.4\end{array}$ & $\begin{array}{c}68.8 \\
52.3 \\
44.7\end{array}$ & $\begin{array}{l}2.4 \\
13.9 \\
18.2\end{array}$ \\
\hline
\end{tabular}


54 W. Christensen og G. Larsen: Tungsandsforekomster i Danmark.

magnet fjernedes malmsandet, idet man dog ikke kunne få dette med svagere magnetisme, end hvad der fandtes i de stærkest magnetiske granatkorn.

Magnetit blev frasorteret med en afstand fra magneten på $10 \mathrm{~mm}$ og der foretoges med magneten en yderligere rensning af den svagere magnetiske malm, således at vi undgik indblanding af granater af betydning. Sorteringen blev foretaget på rent tungsand (vægtfylde over 2.9), og hver prøve blev på denne måde opdelt i 3 fraktioner: 1) magnetit, 2) ilmenit-hæmatit og 3) rest, idet dog et par prøver af ilmenit-hæmatit yderligere blev opdelt i to fraktioner med magneten. Der blev derpå efter pulverisering af prøverne foretaget kemisk analyse af malmfraktionerne, hvor disse var på over $5 \%$ af tungsandet. Malmen blev bragt i opl $\varnothing$ sning ved smeltning med kaliumpyrosulfat. I smeltemassen blev foretaget bestemmelse af $\mathrm{Fe}$, Ti og uopløselig rest. Under forudsætning af, at Ti findes som ilmenit og jern som magnetit i den stærkt magnetiske fraktion og som hæmatit i den svagtmagnetiske fraktion, fremkommer det i tabellen angivne mineralindhold i fraktionerne.

Af tabellen fremgår, at kun lokaliteterne Skallerup, Fjaltring, Uggerby og Harboøre samt Liseleje indeholder stærk magnetisk malm (magnetit) i mængder, der har praktisk betydning, medens alle lokaliteter indeholder svagt magnetisk malm (ilmenit-hæmatit). Af tabellen fremgår videre, at de stæerkt magnetiske fraktioner har en ret ensartet kemisk sammensætning, mens de svagtmagnetiske fraktioner varierer stærkt fra forskellige lokaliteter, men så vidt det kan skǿnnes ud fra de ret få analyser, er ret ensartet indenfor samme område, som det også vil frremgå af nedenstående sammenstilling fra jyske lokaliteter med flere analyser.

\begin{tabular}{|c|c|c|c|}
\hline Forekomst & $\begin{array}{l}\text { Antal } \\
\text { prøver }\end{array}$ & Stærkt magnetisk malm & Svagt magnetisk malm \\
\hline Lønstrup-Skallerup & 4 & $\begin{array}{l}22-38 \% \text { af tungsand, med } \\
67-70 \% \mathrm{Fe}\end{array}$ & $\begin{array}{l}23-38 \% \text { af tundsand, med } \\
22-25 \% \mathrm{TiO}_{2}\end{array}$ \\
\hline Fjaltring. . . . . . . . & 3 & $\begin{array}{l}19-30 \% \text { af tungsand, med } \\
\quad 63-68 \% \mathrm{Fe}\end{array}$ & $\begin{array}{l}32-48 \% \text { af tungsand, med } \\
16-21 \% \mathrm{TiO}_{2}\end{array}$ \\
\hline Skagen-Hulsig ..... & 4 & $\begin{array}{l}0.6-2 \% \text { af tungsand; } \\
\text { ingen analyse }\end{array}$ & $\begin{array}{l}9-39 \% \text { af tungsand, med } \\
18-25 \% \mathrm{TiO}_{2}\end{array}$ \\
\hline Kandestederne .... & 4 & $\begin{array}{l}0.6-0.8 \% \text { af tungsand; } \\
\text { ingen analyse }\end{array}$ & $\begin{array}{l}10-19 \% \text { af tungsand, med } \\
34-38 \% \mathrm{TiO}_{2}\end{array}$ \\
\hline Holmsland Klit. ... . . & 7 & $\begin{array}{l}1-4 \% \text { af tungsand; ingen } \\
\text { analyse }\end{array}$ & $\begin{array}{l}16-34 \% \text { af tungsand, med } \\
\quad 36-40 \% \mathrm{TiO}_{2}\end{array}$ \\
\hline
\end{tabular}

Af sammenstillingen fremgår, at tungsandet fra Skallerup og Fjaltring har et betydeligt indhold af malm, omtrent lige meget af magnetit og blandingen ilmenit-hæmatit. Analyserne af fraktionerne 
viser, at den stærkt magnetiske magnetitfraktion indeholder op mod $70 \% \mathrm{Fe}$ og derfor langt overvejende består af magnetit. Indholdet af $\mathrm{TiO}_{2} \mathrm{i}$ det svagt magnetiske malmsand ligger på under det halve af indholdet i ren ilmenit, og det må derfor overvejende bestå af hæmatit (eventuelt også indlejret magnetit).

Fra de фvrige tre områder findes der nærmest kun spor af magnetit, og indholdet af ilmenit-hæmatit-fraktionen er lav. Medens titanindholdet i den svagt magnetiske fraktion fra Skagen-Hulsig er af samme størrelsesorden som i de ovenfor omtalte, så ligger det i tilsvarende fraktion fra Kandestederne og Holmsland klit omtrent på den dobbelte, og variationen er i prøverne herfra meget ringe, selv om prøverne begge steder er fordelt på en strækning på flere km.

I prøverne løbe nr. 61 (Holmsland klit), 69 (Skallerup), 89 (Fjaltring) og 5 (Liseleje) er der foretaget en videre magnetisk sortering af det svagt magnetiske materiale, idet der er sorteret fra, hvad der kunne tages med den halve magnetafstand, som anvendtes ved frasortering af magnetit. Den stærkest magnetiske delfraktion betegnes i nedenstående sammenstilling af titanindholdet med I, resten med II.

\begin{tabular}{|c|c|c|c|c|c|c|c|c|}
\hline Løbe nr. & \multicolumn{2}{|c|}{61} & \multicolumn{2}{|c|}{69} & \multicolumn{2}{|c|}{89} & \multicolumn{2}{|c|}{5} \\
\hline$\% \mathrm{TiO}_{2} \ldots$ & I. 28,9 & II. 41,5 & I. 15,0 & II. 28,6 & I. 4,5 & II. 23,8 & I. 23,1 & II. 30,4 \\
\hline
\end{tabular}

Analyserne af fraktionerne viser, at den svagest magnetiske del i alle tilfælde har det h $\varnothing$ jeste indhold af titan. Endvidere viser denne undersøgelse, at en magnetisk ensartet fraktion fra forskellige lokaliteter har et stærkt varierende indhold af titan, og at det derfor ikke ene kan være forholdet ilmenit-hæmatit, der bestemmer de enkelte korns magnetisme.

Det er da også en kendt sag, at mineralerne magnetit, hæmatit og ilmenit og rutil ofte optræder sammen selv i meget små mineralkorn, og under sådanne forhold kan der ikke foretages en magnetsortering, der giver rene mineraler.

Hele spørgsmålet om fremstilling af de reneste mineralfraktioner kan kun løses ved malmmikroskopiske undersøgelser af forskelligt fremstillede fraktioner, og man må regne med, at de forskellige lokaliteter kræver individuel fraktionering til fremstilling af de reneste og dermed mest $\not k$ konomiske mineralkoncentrater.

De $\varnothing$ konomisk vigtige mineraler.

På grundlag af de foretagne undersøgelser skal der gives en kort omtale af de mineraler, der særlig vil være af interesse ved undersøgelsen og udnyttelsen af tungsandet ved vore kyster. 
Magnetit lader sig let isolere ved hjælp af faste magneter. De foretagne undersøgelser tyder på, at der kan fremstilles koncentrater med omkring 67 til $70 \%$ Fe og med $2-4 \%$ ' $\mathrm{Ti}_{2}$ (ren magnetit indeholder $72.4 \% \mathrm{Fe}$ ). Kun en del af de undersøgte forekomster indeholder magnetit i mængder af betydning. De bedste af de store forekomster er Skallerup og Fjaltring, der ved nogle sorteringer med håndmagnet har givet over $30 \%$ magnetit, og ved sortering af større prøver på Kryolitselskabets magneter har givet 22 og $23 \%$ magnetit. Tungsandet ved Nordsjællands kyster har også et betydeligt indhold af magnetit. (Sml. tabel p. 53). Magnetit er en stærkt efterspurgt jernmalm.

Ilmenit forekommer, som det fremgår af det foregående, overalt med for lavt indhold af $\mathrm{TiO}_{2}$ på grund af indblanding af hæmatit. Ilmenitkoncentrat fra Skallerup har således efter såvel sortering med håndmagnet som ved de forskellige andre former for magnetsortering kun indeholdt ca. $24 \% \mathrm{TiO}_{2}$. Koncentrater fra Fjaltring og Skagen har et lignende indhold af $\mathrm{TiO}_{2}$, medens koncentrater fra Kandestederne og Holmsland indeholder omkring 35-40 \% $\mathrm{TiO}_{2}$. Det kan vel forventes, at det ved skarp sortering vil være muligt at hæve indholdet af $\mathrm{TiO}_{2}$ i ilmenitkoncentratet. Ilmenit, der kommer på markedet, indeholder $\mathrm{i}$ almindelighed over $40 \% \mathrm{TiO}_{2}$, de gode kvaliteter omkring $55 \% \mathrm{TiO}_{2}$, altså lidt mere end det rene mineral, $\mathrm{FeTiO}_{2}$, der indeholder $53 \% \mathrm{TiO}_{2}$.

Ilmenit er langt den vigtigste titanmalm, og da efterspørgslen efter titan i de senere år er mangedoblet, vil det være af stor betydning ved udnyttelsen af det danske tungsand, om man kan fremstille ilmenitkoncentrater, der kan finde afsætning til industrielle formål.

Zirkon vil næppe heller blive vanskeligt at isolere. I de allerfleste af de undersøgte prøver med højt indhold af tungmineral viser de petrografiske analyser af nord-og vestjydske forekomster et indhold på mellem 5 og $10 \%$ zirkon. Set på baggrund af zirkonforekomsterne i U.S. A. (saml. side 48), hvor man opgiver zirkonindholdet til omkring $0.5 \%$, må vort tungsand regnes for et meget fint udgangsmateriale. Også sammenlignet med de australske tungsandsforekomster, hvor man for en stor del går ud fra et råstof med et samlet tungmineralindhold af samme størrelsesindhold som zirkonindholdet $\mathrm{i}$ vore forekomster, og hvor kun en mindre del af tungmineralerne er zirkon, må vort tungsand regnes for et fint udgangsmateriale til fremstilling af rent zirkon. Der er ikke foretaget kemiske analyser af zirkon, men de petrografiske analyser foretaget af H. PAUly i forbindelse med separering af de store prøver viser, at zirkonkornene overvejende er umagnetiske og da meget rene. En mindre del af zirkonsandet er svagt magnetisk, og denne del er ikke 
fuldt så rent. Ud fra de hidtil foretagner undersøgelser må man således regne med, at der kan fremstilles omkring $50 \mathrm{~kg}$ zirkonsand pr. ton godt koncentreret tungsand.

Når man ser bort fra den enkelte analyse fra Bornholm, ser det efter de foretagne undersøgelser ud til, at forekomsterne på фerne har et betydeligt lavere zirkonindhold end forekomsterne i Nord- og Vestjylland.

Granat kan koncentreres som ret rent mineral. Det er vel ikke noget særligt efterspurgt mineral, men det angives stadig at have en del anvendelse som slibemiddel. Man finder også angivelser af, at hvor man har granat i større mængder, anvendes det som tilslag ved jernudsmeltning. Ved omtale af tungsand og dets udnyttelse ser man da også nogle steder granat henregnet til de $\phi$ konomiske mineraler (NAKHLA 1958 og forskellige håndbøger).

Ved en eventuel udnyttelse af tungsand må opmærksomheden også rettes mod de andre mineraler, der findes i tungsandet. I en omtale af de amerikanske forekomster, der danner udgangsmateriale for zirkonfremstilling (WEsseL 1958), anføres således, at staurolit har en vis betydning i cementfabrikationen.

Med den betydelige forskel, der er i koncentrationen af tungmineraler fra sted til sted og inden for samme forekomst fra tid til anden, må det være rimeligt i første omgang at udnytte de bedste koncentrater, tilmed da det synes at være så heldigt, at disse har det højeste indhold af magnetit og zirkon, der indtil videre må regnes for de $\phi$ konomisk vigtigste mineraler.

Ved opsamling af tungsand vil det være en fordel i første omgang at tage de mest rene, mørke overfladelag, hvor sådanne findes. I mange tilfælde vil der uden tvivl inden længe dannes nye, koncentrerede overfladelag, og sådanne b $\varnothing \mathbf{r}$ altid opsamles, $\mathbf{f} \phi \mathbf{r}$ de bliver tildækket af mindre koncentrerede lag. De gode koncentrerede lag har ofte kun en mægtighed på nogle få $\mathbf{c m}$, men da de ligger meget jæunt, lader de sig nemt samle, når de ligger som overfladelag, medens det straks bliver vanskeligere, når disse tynde lag først skal afdækkes. Påbegyndes produktionen på denne måde, vil man også hurtigt få nogen erfaring for, når og hvor hurtigt sådanne gode koncentrationslag gendannes. 


\section{AFSLUTTENDE BEMARKNINGER}

Medens man rundt om i verden udnytter forekomster af tungsand, ofte med et ringe indhold af anvendelige mineraler, så må man herhjemme ved en eventuel udnyttelse af tungsandet i samarbejde med naturkræfterne finde frem til den mest rationelle måde for at udnytte de gode koncentrater på strandens overflade. Ved en sådan form for udnyttelse vil man få gode koncentrater at gå ud fra, men til gengæld må udnyttelsen samtidig foregå over store områder, således at man enten får transport over store afstande, eller også må foretage oparbejdningen på mange steder.

De unders $\varnothing$ gelser vedrørende tungsand, som startede i 1956, og som er fortsat ved tid og lejlighed, har åbenbart givet sådanne resultater, at der nu påbegyndes en forsøgsvis udnyttelse af dette hidtil her i landet upåagtede råstof. Der er grund til at nære de bedste forhåbninger til, at en sådan produktion kan gennemføres på god $\varnothing$ konomisk basis. Set i forhold til de mængder af tungsand, der findes rundt om i verden, er vore forekomster kun små. Det gælder da om at udnytte det vi har så rationelt som muligt, og en absolut forudsætning for dette vil være, at man får foretaget en grundig eftersøgning for og undersøgelse af vore tungsandsforekomster samtidig med, at man søger at blive klar over, i hvor høj grad der tilføres stranden nyt tungsand og i hvor store mængder, ligesom det ved udnyttelsen vil være af betydning at fange så meget af råstoffet som muligt, altså hindre, at det en gang koncentrerede tungsand atter spredes for eventuelt at ende i havet eller i klitterne i så svage koncentrationer, at det ikke kan udnyttes i produktionen.

Som grundlag for en rationel udnyttelse af tungsandet som helhed vil det uden tvivl være af betydning med en systematisk undersøgelse. Formålet med en sådan undersøgelse må være:

1. Ved en gennemgang af alle vore kyster at finde frem til, hvor der optræder tungsandskoncentrater. Man b $\phi r$ her ikke alene interessere sig for forekomster af gode koncentrater i sådanne mængder, at der er mulighed for udnyttelse, men man b $\phi r$ også interessere sig for spredte forekomster og svage koncentrater, da vore erfaringer har lært os, at tilstanden på stranden stadig ændres. 
2. I de gode, permanente forekomster fors $\emptyset$ gsvis ved opmåling af profiler gravet med regelmæssige mellemrum vinkelret på kysten at foretage en opmåling af mængden af tungsand. Ved denne opmåling må der skelnes mellem de forskellige former for aflejring, ligesom man må opфve evnen til at skønne over indholdet af tungmineraler.

3. Foretage iagttagelșer og opmålinger af udvalgte områder ved forskellige årstider og efter storme af forskellig styrke for at iagttage de ændringer, lokaliteterne bliver udsat for.

4. I forbindelse med undersøgelserne at udtage prøvemateriale, der dækker variationer i koncentration og forholdet mellem de enkelte mineraler i de forskellige områder samt variationen indenfor de enkelte områder.

5. Gennem laboratorieundersøgelser af de udtagne prøver at finde ud af det samlede mineralindhold og mineralfordelingen fra sted til sted og indenfor samme område fra tid til anden, og derved også indholdet af de enkelte mineraler i varierende koncentrationer.

Ved en unders $\varnothing$ gelse efter ovenstående plan skulle der være mulighed for at skønne over, hvad der tilf $\phi$ res af nyt materiale, og hvorfra dette kommer. Der kan derfor også i forbindelse med en undersøgelse være anledning til at få et mål for nedbrydning i nogle klinter og analyser af klinternes materiale.

Da den første udnyttelse af tungsandet kan omfattes som en fors $\varnothing$ gsproduktion, vil det være af stor betydning, at man ved en eventuel udvidelse af produktionen kender så meget til mængder og placering af tungsand som muligt, ligesom kendskabet til fornyelsesmuligheder efter fjernelse af de $\varnothing$ vre koncentrater og mulighederne for tilførsel af nyt materiale, og hvorfra dette kommer, vil være af stor værdi, ja nærmest en nødvendig forudsætning for en rationel udnyttelse af tungsandet ved vore kyster. 


\section{SUMMARY}

A study of the occurrences of heavy minerals along the shores of Denmark was begun in 1956 for the purpose of ascertaining the possibility of their exploitation. So far the work has been purely orienting in character, comprising the following investigations:

1. Field: reconnaissance in the coastal regions; estimation of the nature and extent of the occurrences;

2. Laboratory: petrographical and chemical analyses of the mineral composition of the deposits.

\section{Occurrences and their formation.}

There are heavy minerals everywhere in Danish sand deposits, but it is only at few localities that these minerals are present in large concentrations.

Large deposits of heavy minerals were found in the following localities along the north and west shores of Jutland: Skagen, Kandestederne, Uggerby, Lønstrup, Fjaltring, Lyngvig. In addition there are fairly good deposits at Liseleje, on the coast of North Zealand. Reconnaissance elsewhere has not so far established the presence of large accumulations of wel-concentrated heavy mineral sand.

Plates II to VII show examples of how the heavy mineral sand occurs. Generally speaking, the large deposits are to be found in the highest areas of the beach.

Observations in the field have established the fact that the concentration of the heavy minerals is a result mainly of the redeposition and sorting of the beach material by the waves, but also that coastal currents play their part too by their contribution to the transport of material along the coast. Finally, in dry periods the wind may rearrange the heavy mineral sand deposited by the waves.

One pre-requisite of the accumulation of large occurrences seems to be that the area of deposition is adjacent to areas of erosion which supply material. The transported heavy minerals concentrate on the upper part of the beach in periods of high water level and heavy breakers.

\section{Mineral content.}

Petrographic and chemical methods were employed for determining the mineral content of the sand. The results are shown in Plate $I$ and in the table page 36 . Chemical analyses were also made of some magnet-separated 
samples, with results as shown in tables pp. 52 and 54. The diagrams p. 35, $38,40,44$ and 45 illustrate other features of the mineral distribution.

The mineral analyses make it evident that the mineral composition of a heavy mineral sand deposit is the outcome of the interplay of the following factors:

1) the composition of the primary material, 2) assortment during the material migration along the shore, and 3 ) assortment during the concentration process on the beach. The importance of the role played by the primary material is traceable inter alia in the fact that zircon is present in large quantities in Jutlandic deposits but only very moderately so on the islands (apart from Bornholm). The circumstance that there are considerable quantities of magnetite in deposits close to glacial erosion coasts, whereas the mineral is only faintly represented in deposits on the sand spit within the same coastal region, is assumed to signify an assortment of the minerals during the material transport. The differences in the composition of the heavy mineral spectrum within the same deposit are always closely related to the degree of concentration in the material, an increase in the heavy-mineral concentration being accompanied by an increase in the content of the heaviest minerals in the heavy-mineral fraction. The apparent cause of this is that in the process of heavy mineral sand formation the waves assort the mineral grains according to weight.

\section{Possibilities of exploitation.}

Large, well-concentrated deposits of heavy mineral sand occur on beaches having an aggregate length of 25 kilometres. Most of them are in the north of Jutland. It is estimated that these deposits contain about 100,000 tons of well-concentrated heavy mineral sand.

Of the minerals in the heavy sand the following are considered to be of primary economic importance:

Magnetite: is a fairly pure mineral, the content of extraneous components being small. Occurs in large quantities at Uggerby, Lønstrup, Fjaltring and in northern Zealand.

Ilmenite: contains large amounts (averaging about 50 per cent.) of haematite in the form of imbedded lamellae; as a consequence, the value of this mineral is doubtful. Occurs inconsiderable amounts in all large deposits of heavy minerals.

Zircon: the composition of this mineral has not been determined in detail, though most of the grains are known to be free from iron; some grains contain Th and/or U. Found in considerable quantities in all large Jutlandic deposits but insignificantly in the occurrences of northern Zealand.

Extraction of the minerals will give rise to concentrates of other minerals which may be of practical importance. This applies for instance to garnet, which is present in abundance in all deposits, as well as rutile and titanite, which likewise form part of all deposits but in very small quantities.

As a result of these investigations an extraction of the minerals is in such a stage of planning that an exploitation plant is being erected. 


\section{LITTERATUR}

D.G.U. = Danmarks geologiske Undersøgelses skrifter, København.

D.G.F. = Meddelelser fra Dansk geologisk Forening, København.

Bülow, KuRd von, 1951. Schwermineral-Seifen an der mecklenburgischen Ostseeküste. Archiv für Lagerstättenforschung. Berlin 1951.

Coetzee, C. B., 1957. Ilmeniethoudende Sand langs die Weskus in die Distrik Vanrhynsdorp. Med engelsk Resumé. Unie van Suid-Afrika. Geologiese opname. Bulletin 25. 1957.

Correns, C. W., 1949. Einführung in die Mineralogie. Berlin, Göttingen, Heidelberg.

DAnø, J. K., 1911. Rationelle Mørtel- og Betonblandinger. Ingeniøren, vol. 20, No 4, p. 35. København.

de Mille, John B., 1947. Strategic Minerals. New York and London. 1947.

Forchнамmer, J. G., 1869. Klitterne på Vestsiden af den jydske Halvø. Almenfattelige Afhandlinger og Foredrag af Johan Georg Forchhammer, ved F. Johnstrup. København 1869. Oprindelig trykt: Dansk Folkeblad VIII. 1842 Nr. 1-3.

Gardner, D. E., 1955. Beach-Sand Heavy-Mineral Deposits of eastern Australia. Commonwealth of Australia. Department of National development. Bureau of Mineral Resources, Geology and Geophysics. 1955.

Gregersen, A. \& Th. Sorgenfrei, 1951. Efterforskningsarbejdet i Danmarks dybere undergrund. D.G.F. Bd. 12, p. 141.

Gry, H., 1956. Om Nexøsandstenen og »Aakerformationen«. En Tungmineral-Korrelation. D.G.F. Bd. 9, p. 27.

Hillebrand, W. F., G. E. F. Lundell, H. A. Bright, J. I. Hoffman, 1953. Applied Inorganic Analysis, (second edition). London.

Jessen, A., 1897. Kortbladene Læsø og Anholt. D.G.U. I. Række Nr. 4.

- 1925. Kortbladet Blaavandshuk. D.G.U. I. Række Nr. 16.

Lamсke, Kunt, 1938. Mineralogische und chemische Untersuchungen an Erzseifen der deutschen Nord- und Ostseeküsten. Geolog. Rundsch. 29 B. Seite 301-306. Stuttgart 1938.

Larsen, G., 1959. Grus til betonstøbning. D.G.F. Bd. 14, p. 77.

Larsen, G., \& A. Dinesen, 1959. Vejle fjord formationen ved Brejning. D.G.U. II. række nr. 82 .

Lindgren, W., 1933. Mineral Deposits. New York, London.

Magnusson, Niels H., 1953. Malmgeologi, Stockholm.

Milner, H. B., 1952. Sedimentary Petrography. London.

Milthers, V., 1935. Nordøstsjællands Geologi. D.G.U. V række nr. 3.

Nakhla, F. M., 1958. Mineralogy of the Egyption Black Sands and its Applications. The Egyptian Journal of Geology. Volume II. Number 1. 1958, p. 1.

O.E.E.C. Titanium Zirkonium. O.E.E.C. 247 (55). 1. 1956.

Poulsen, E., 1958. Preparation of Samples for Microscopic Investigation. The Danish National Institute of Building Research and the Academy of Technical Sciences. Committee on Alkali Reactions on Concrete. Progress Report M. 1. Copenhagen. 
Rittmann, A. \& E. E. El Hinnawy, 1958. A Note on the Quantitative Mineralogical Analysis of Black Sands. The Egyptian Journal of Geology. Volume II. Number 1. P. 67.

Rørdaм, K., 1893. De geologiske Forhold i det nordøstlige Sjælland. Beskrivelse til Kaartbladene »Helsingør « og » Hillerød « D. G. U. I. Række Nr. 1.

Skeat, E. G. \& V. Madsen, 1898. On Jurassic, Neocomian and Gault boulders found in Denmark. D.G.U. II række nr. 8.

Wasmund, Erich, 1938. Die Schwerminerallagerstätten der deutschen Küsten. Geolog. Rundsch. 29 B. Seite 287-300. Stuttgart 1938.

Wessel, F. W., 1958. (Washington) Zirconium Raw-Material Supply. Second United Nations International Conference on the Peaceful Uses of Atomic Energy; Genera Switzerland 1958 .

Weyl, R., 1937. Marine Erz-Granatseifen der schleswig-holsteinischen Küsten und ihre Regelmässigkeiten in der Korngrössen- und Mineralverteilung. Zeitschrift für Geschiebeforschung und Flachlandsgeologie. Bd. 13 p. 63.

Winchell, A. N. \& H., 1951. Elements of Optical Mineralogy. Part II. Descriptions of Minerals. New York, London. 


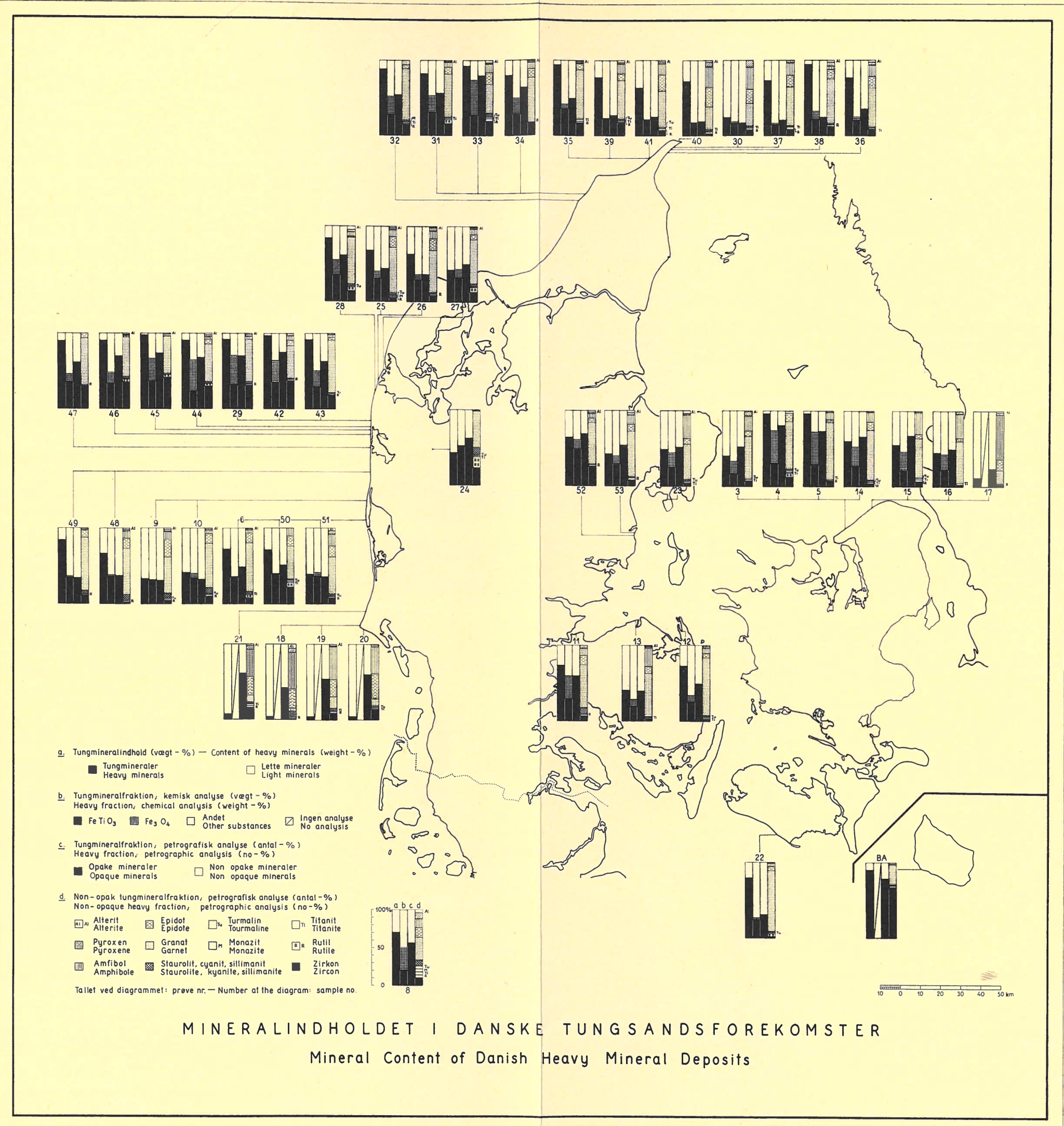




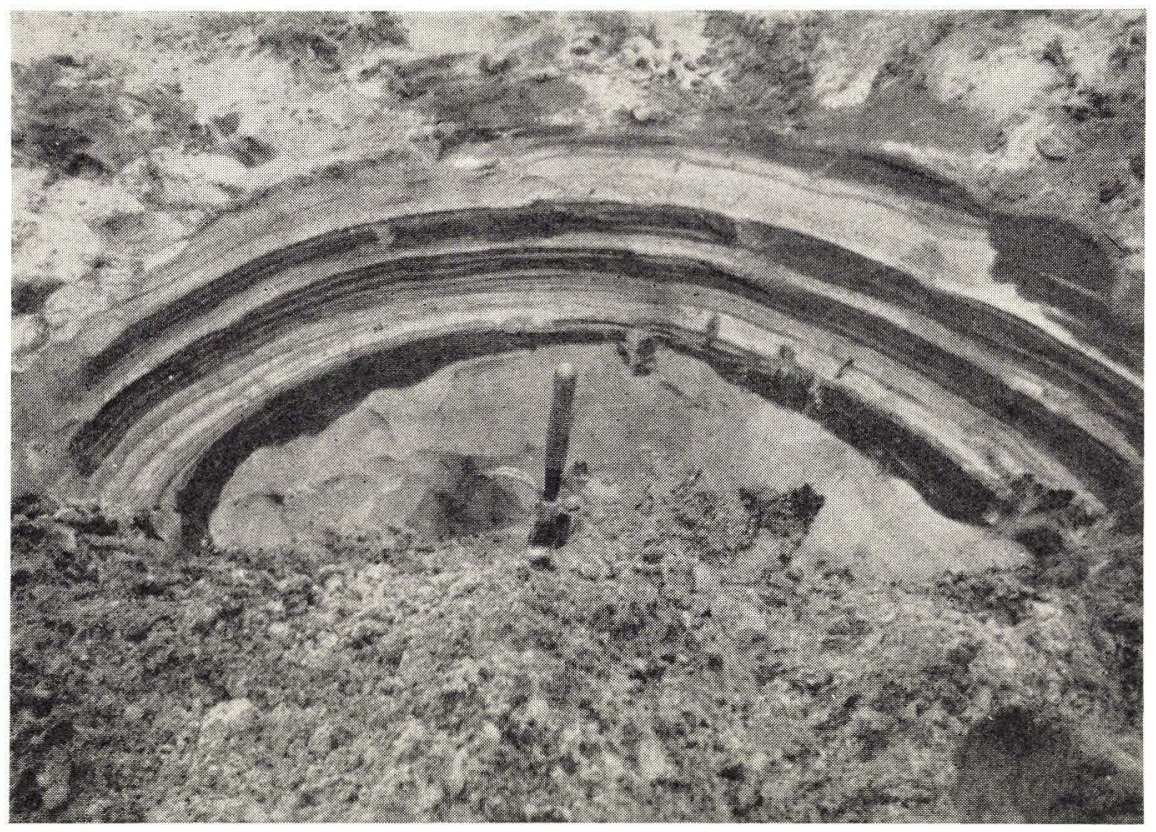

Fig. 1. Profil i tungsandsforckomst, Rågeleje. Marts 1953; G. L. fot. (Træskaftets længde ca. $15 \mathrm{~cm}$.)

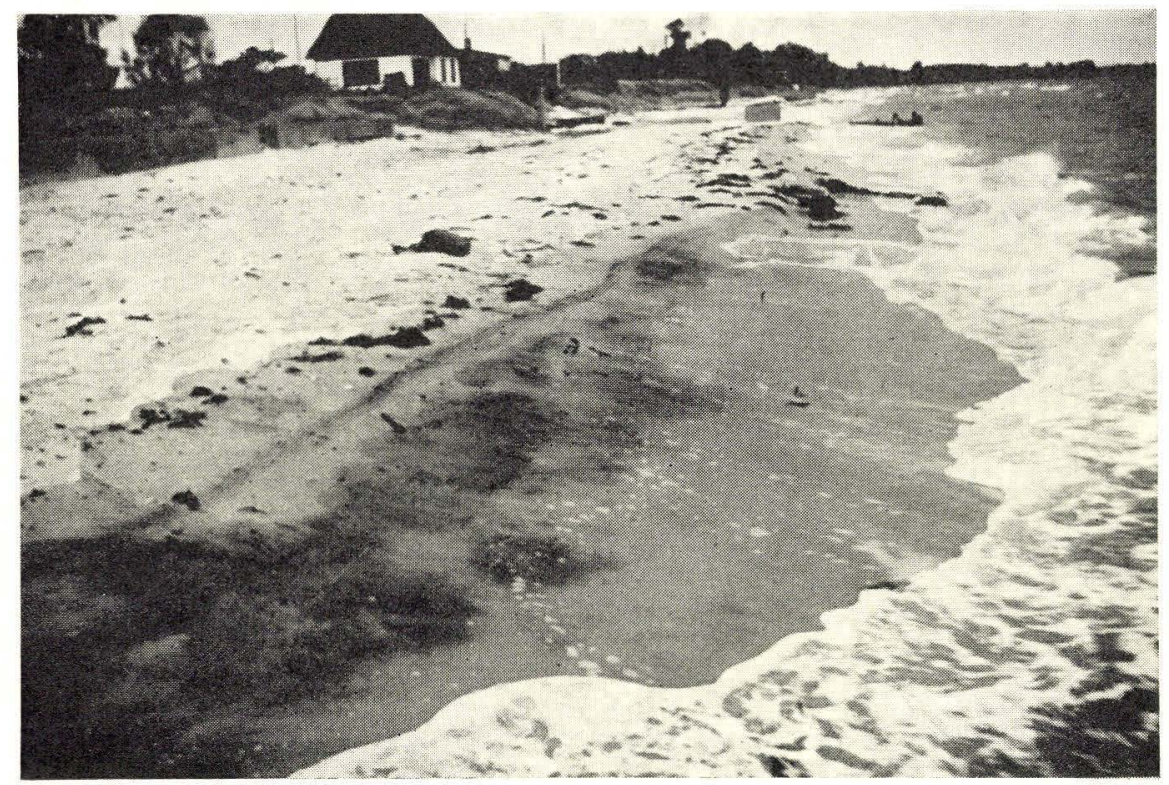

Fig. 2. Koncentration af tungsand i bølgeslagslinien. Saksild Strand. August 1956; G. L. fot. 


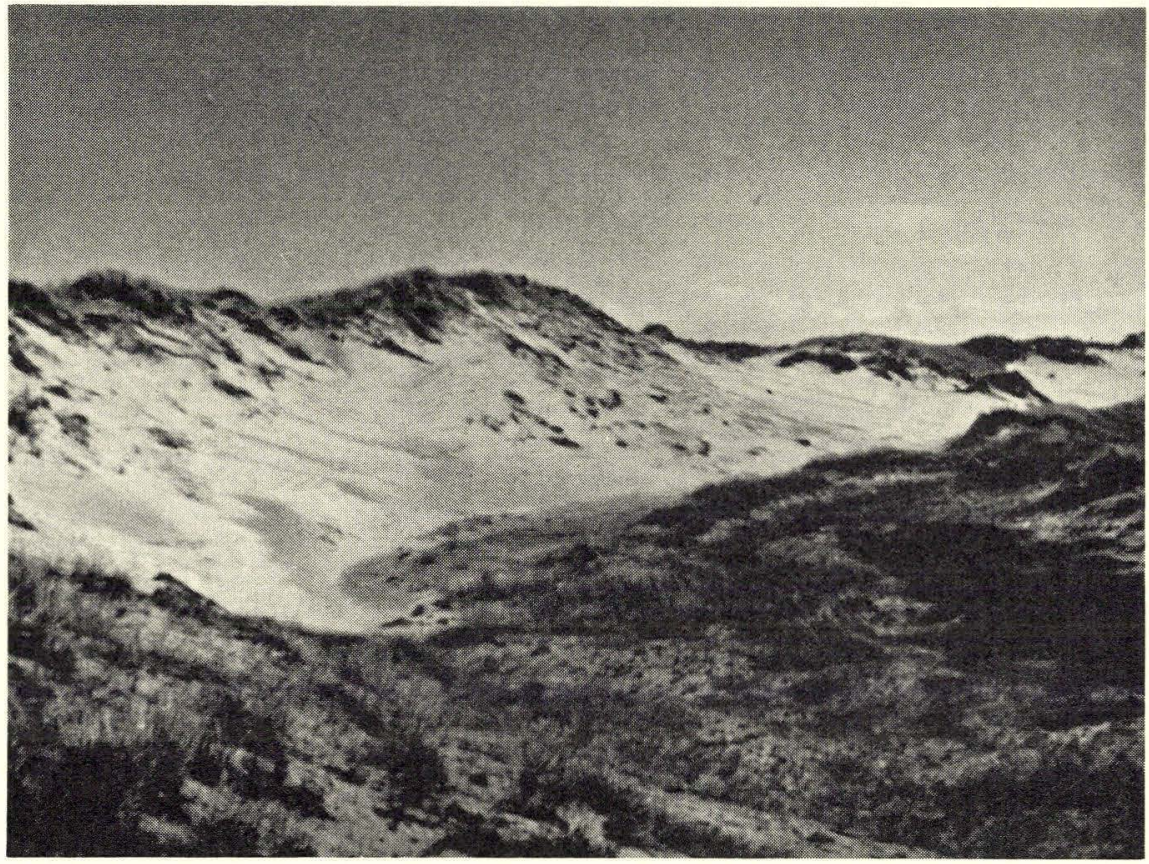

Fig 1. Klit med mørke, tungmineralrige flader. Sandmilen S. for Skagen. August 1956; G. L. fot.

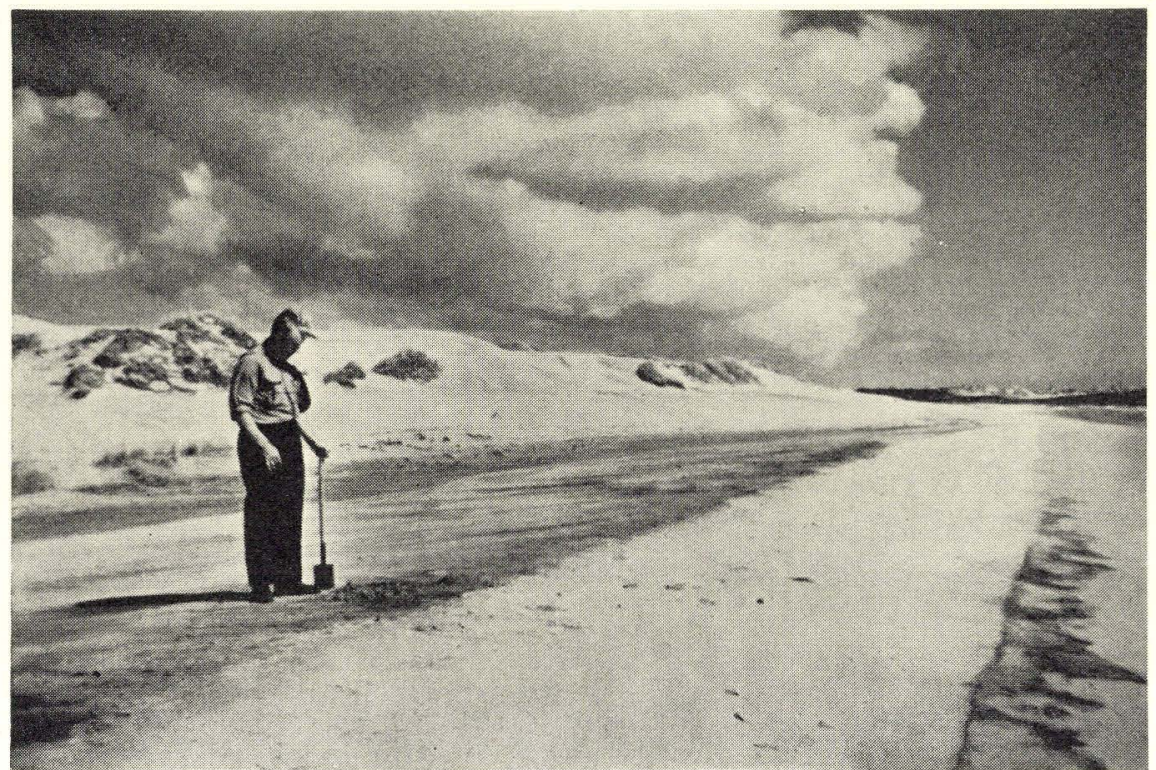

Fig. 2. Tungsandsforekomst på stranden ved Sandmilen S. for Skagen. August 1956; G. L. fot. 


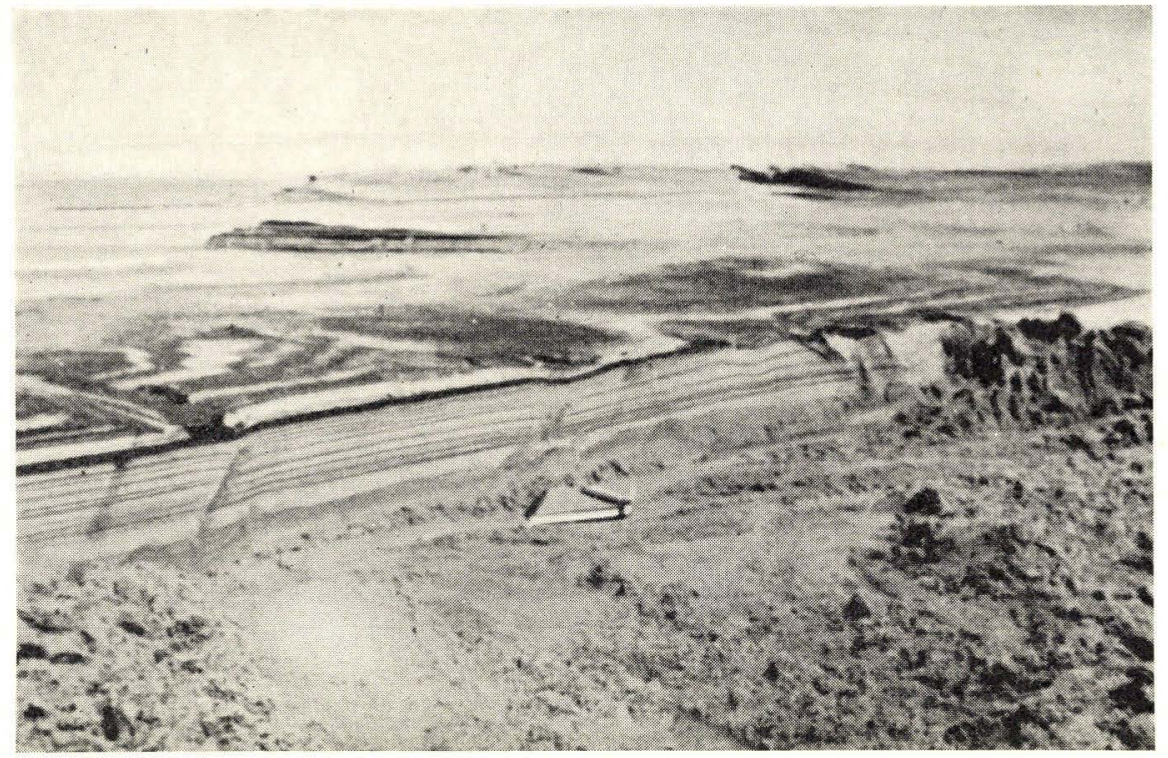

Fig. 1. Profil i tungsandsforekomsten tavle III, fig. 2. August 1956; G. L. fot. (Bogens bredde $10 \mathrm{~cm}$.)

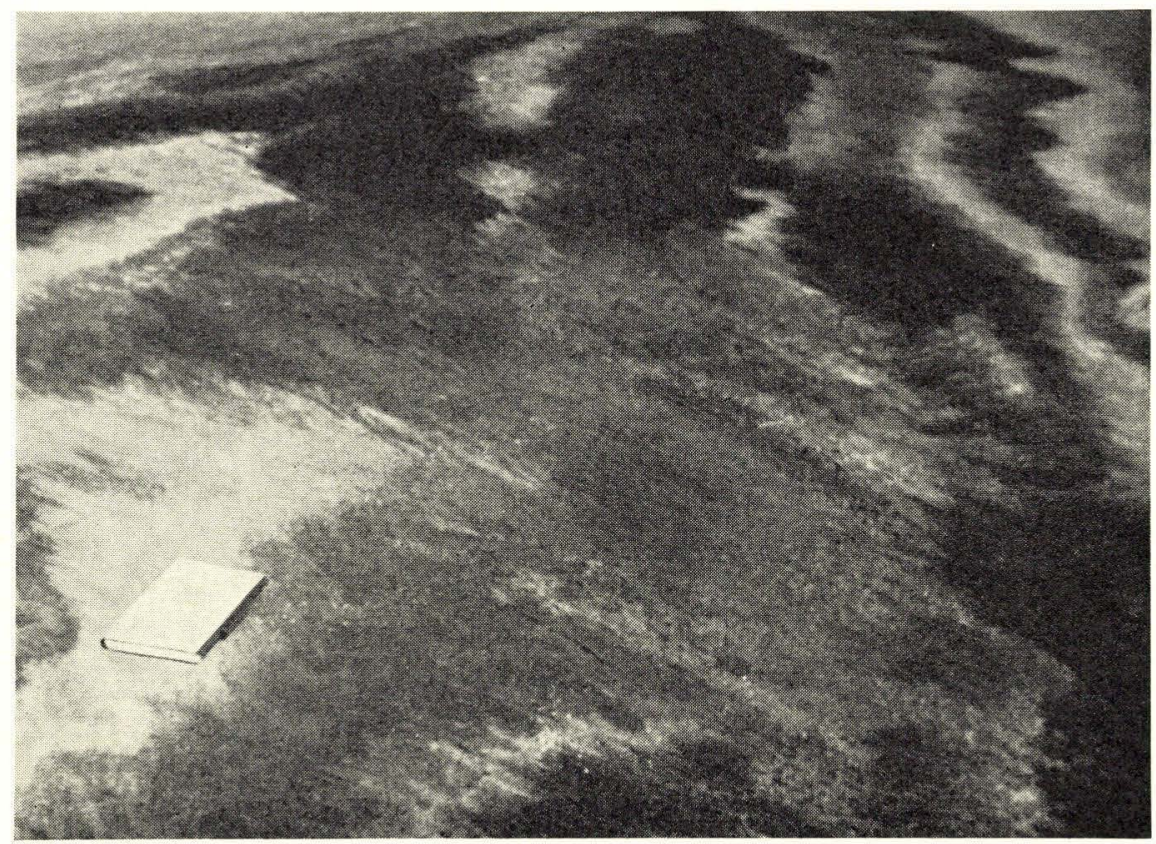

Fig. 2. Overflade af ovennæunte forekomst. August 1956; G. L. fot. (Bogens bredde $10 \mathrm{~cm}$.) 


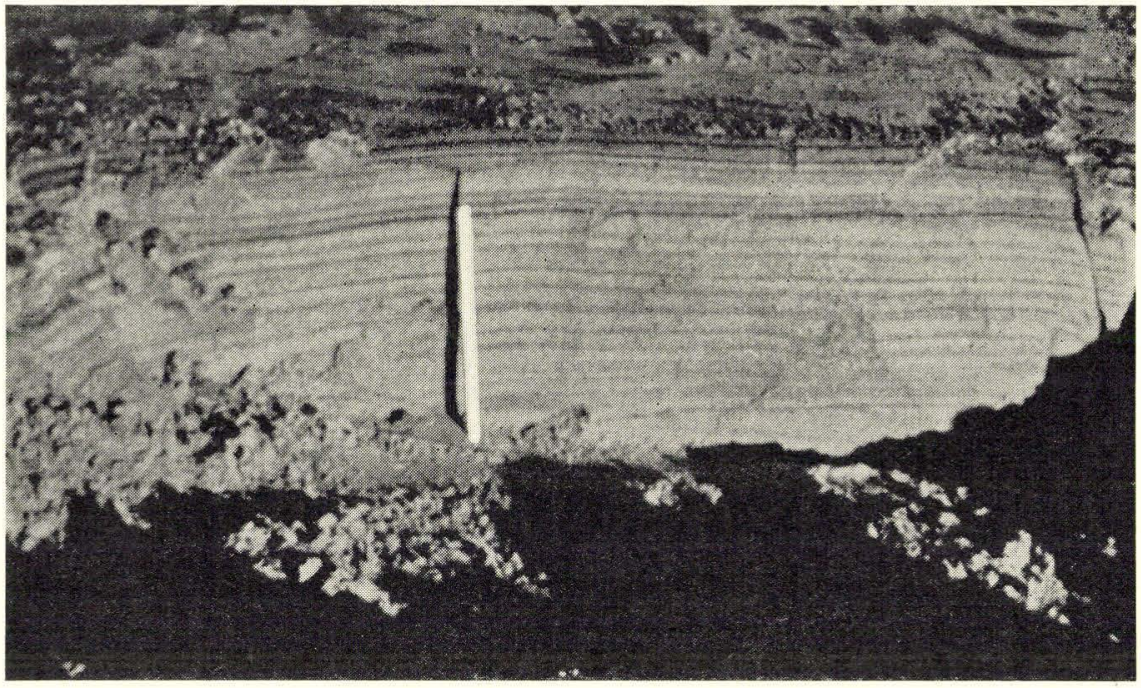

Fig. 1. Profil i strandsand på Skagens Gren. De tynde sorte striber er tungsand. August 1956; G. L. fot.

(Blyantens længde ca. $16 \mathrm{~cm}$.)

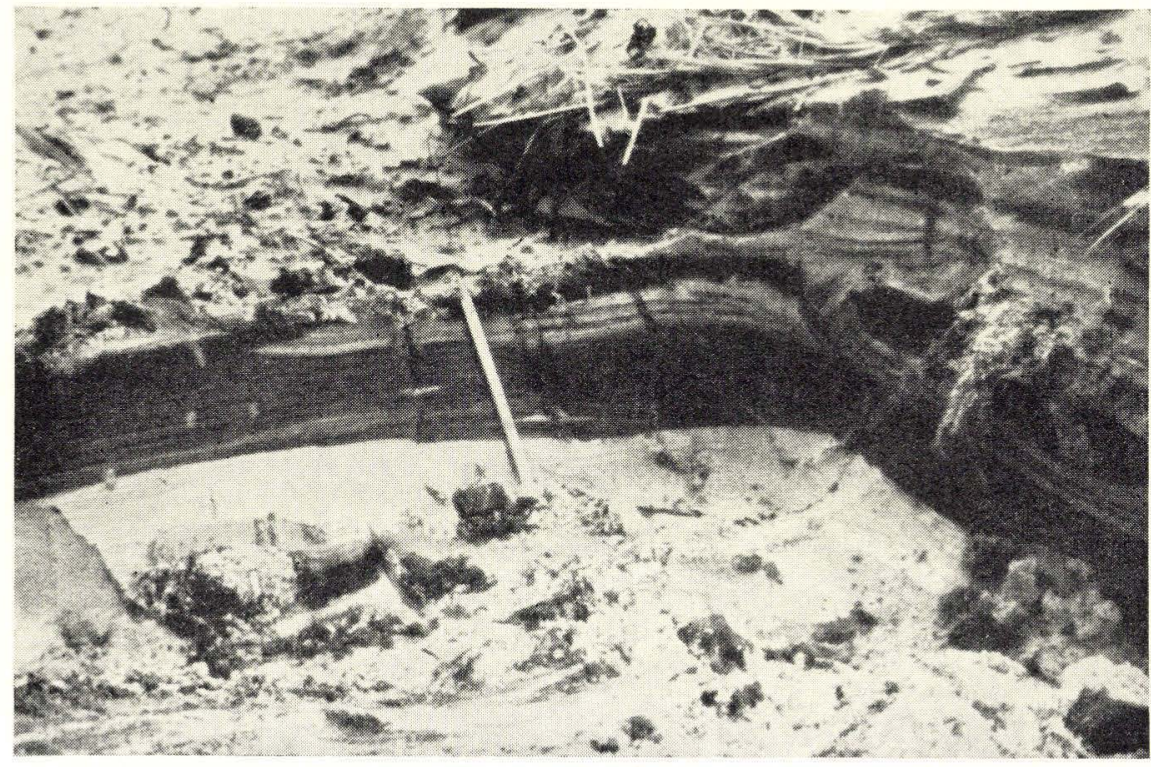

Fig. 2. Profil i tungsandsforekomst. Kandestederne. August 1956; G. L. fot.

(Blyantens længde ca. $16 \mathrm{~cm}$. ) 


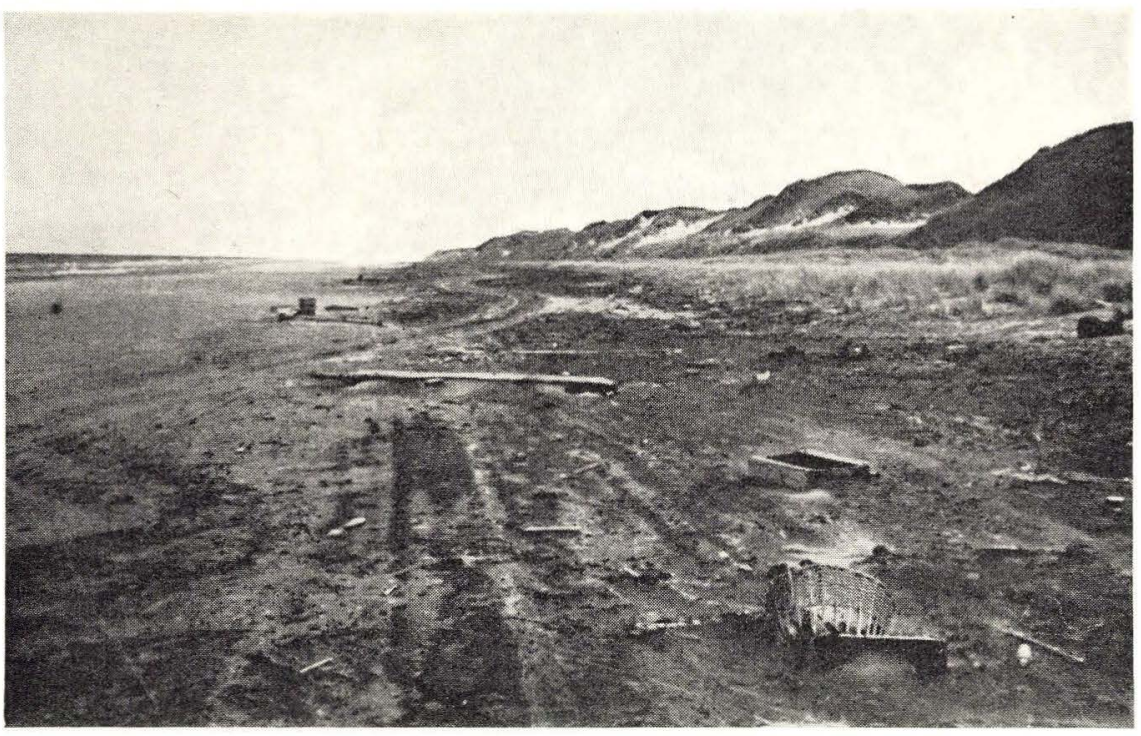

Fig. 1. Stor tungsandsforekomst på den $\emptyset$ vre, delvis tilgroede del af strandbredden ved Kandestederne. August 1956; G. L. fot.

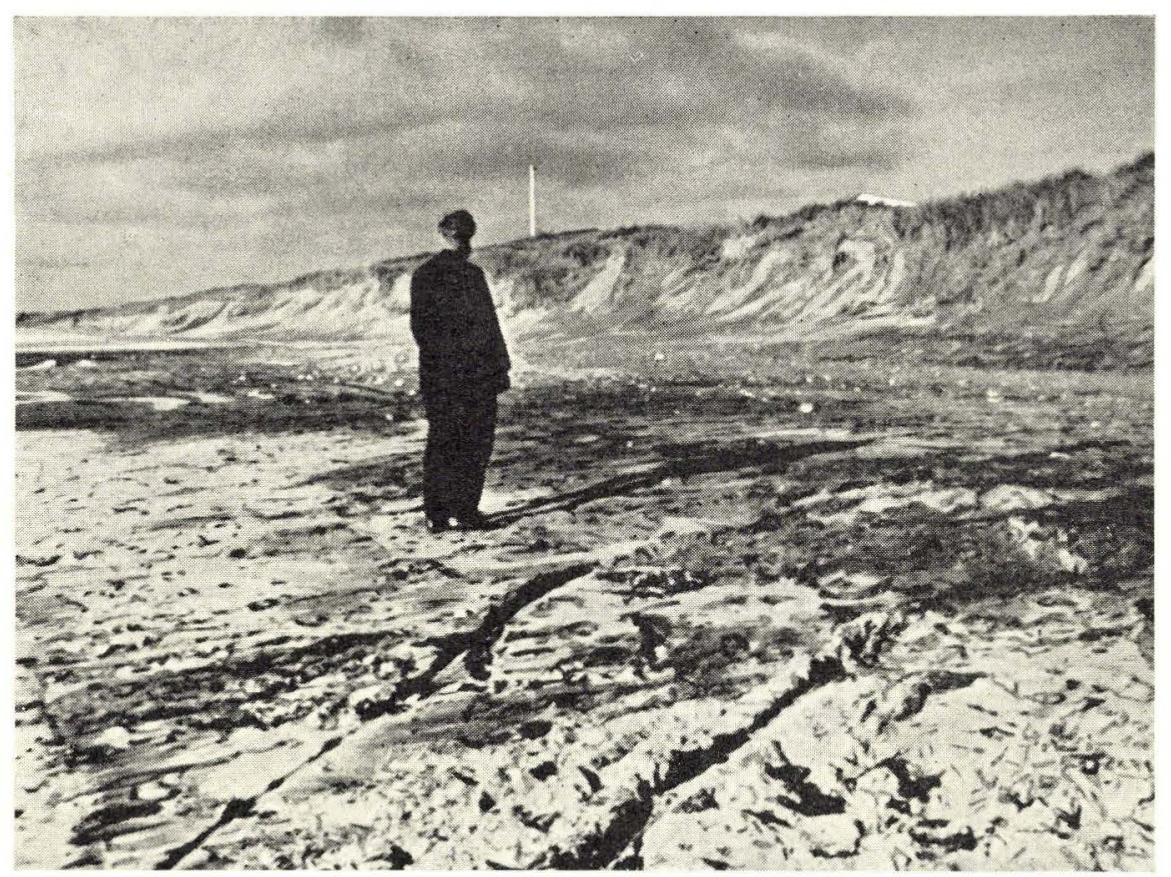

Fig. 2. Stor tungsandsforekomst på den øvre del af stranden ved Skallerup Klit N. for Lønstrup. August 1956; G. L. fot. 


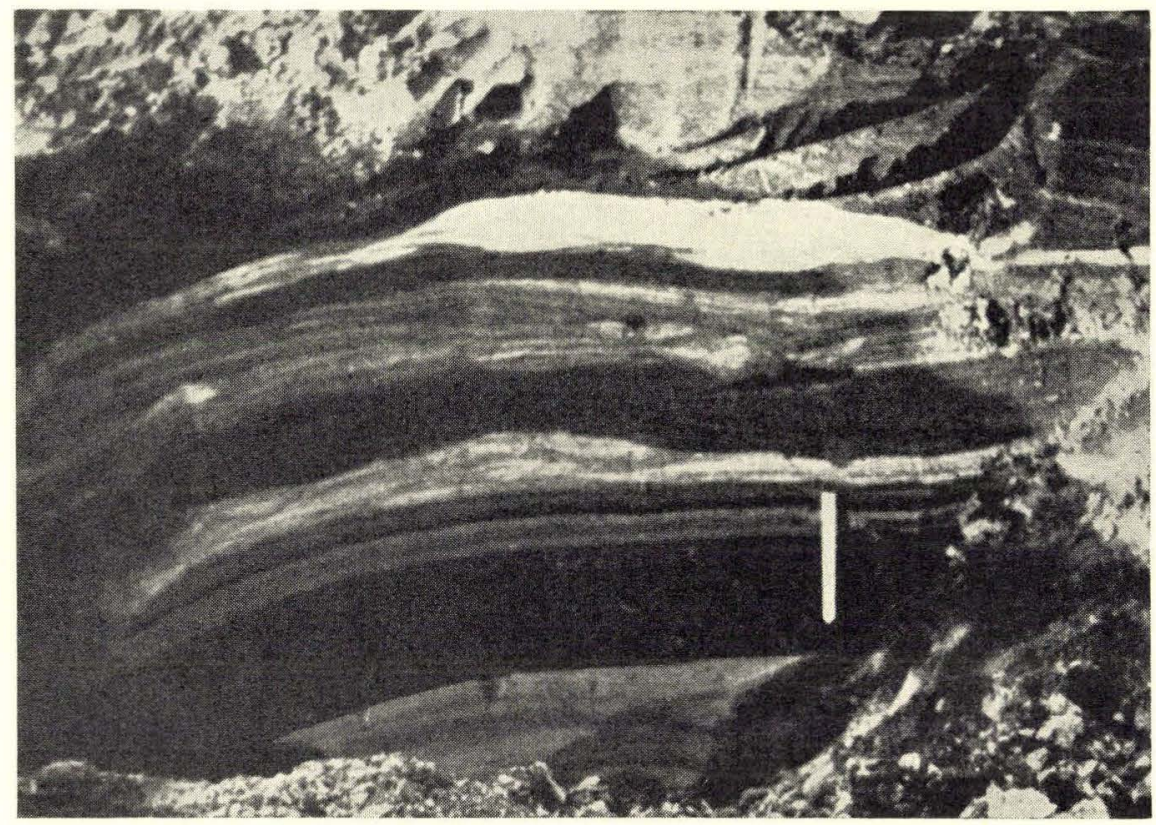

Fig. 1. Profil i tungsandsforekomst på stranden ved Skallerup Klit N. for Lǿnstrup. August 1956; G.L. fot. (Blyantens længde ca. 71/2 cm.)

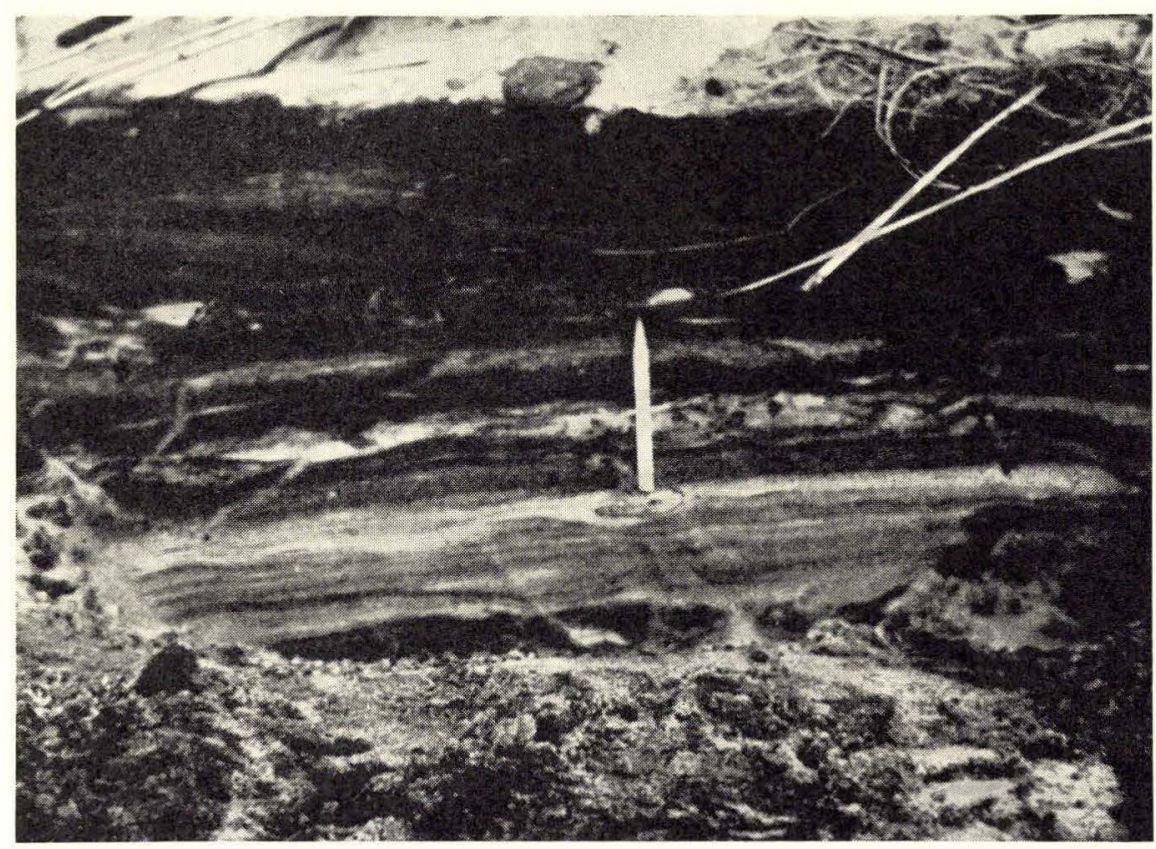

Fig. 2. Profil i tungsandsforekomst på stranden ved Skallerup Klit N. for Lønstrup. August 1956; G. L. fot. (Blyantens længde ca. $7 \frac{1}{2} \mathrm{~cm}$.) 


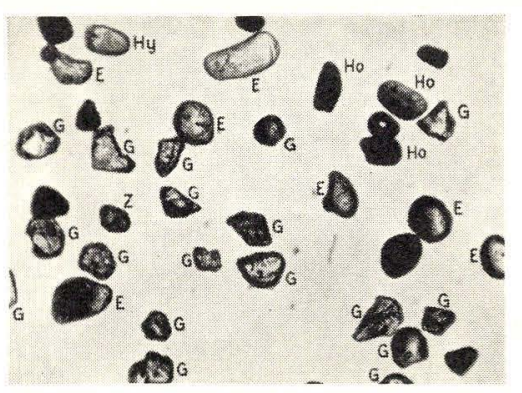

Fig.1. Skagen.

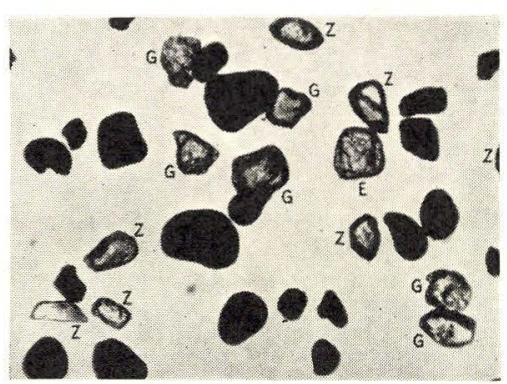

Fig. 3. Fjaltring.

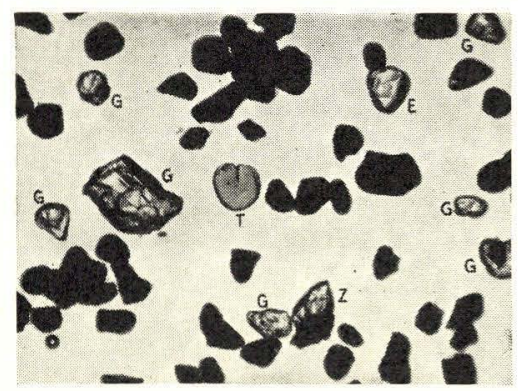

Fig. 5. Liseleje.

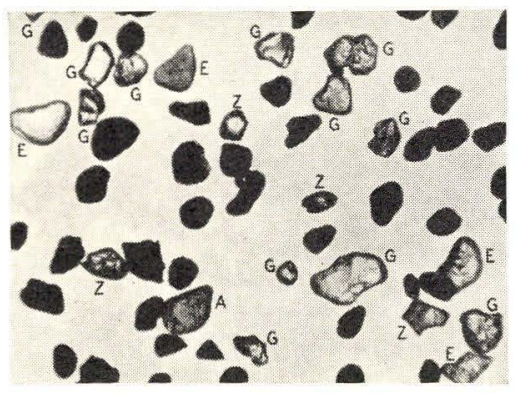

Fig. 2. Lyngvig.

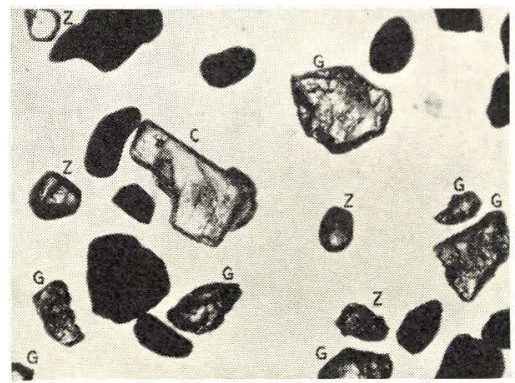

Fig. 4. Holstebro (tertiær).

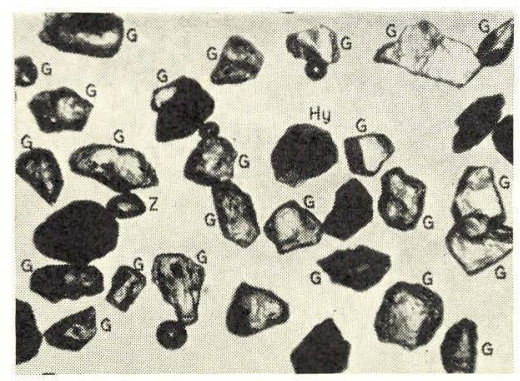

Fig. 6. Rødby Havn.

Udsnit af mineralselskaberne i forskellige tungsandsforekomster. Forstøryelse ca $15 \mathrm{x}$.

Chr. W. fot.

Sorte korn: opak malm (magnetit og ilmenit); gennemskinnelige korn: $\mathrm{A}=$ augit, $\mathrm{C}=$ cyanit, $\mathrm{E}=$ epidot, $\mathrm{G}=$ granat, $\mathrm{Ho}=$ hornblende, $\mathrm{Hy}=$ hypersten, $\mathrm{T}=$ turmalin, $\mathrm{Z}=$ zirkon. 